\title{
OPTIMIZING TECHNOLOGY TO REDUCE MERCURY AND ACID GAS EMISSIONS FROM ELECTRIC POWER PLANTS
}

\section{Final Report August 1, 2003 to October 31, 2005}

Principal Authors Jeffrey C. Quick David E. Tabet Sharon Wakefield Roger L. Bon

Published October 2005

Prepared for The United States Department of Energy Contract No. DE-FG26-03NT41901 Contract Officer Sara M. Pletcher National Energy Technology Laboratory Morgantown, West Virginia

Prepared by The Utah Geological Survey 1594 West North Temple, Suite 3110 Salt Lake City, Utah 84114-6100 (801) 537-3300 


\section{DISCLAIMER}

This report was prepared as an account of work sponsored by an agency of the United States Government. Neither the United States Government nor any agency thereof, nor any of their employees, makes any warranty, express or implied, or assumes any legal liability or responsibility for the accuracy, completeness, or usefulness of any information, apparatus, product, or process disclosed, or represents that its use would not infringe privately owned rights. Reference herein to any specific commercial product, process, or service by trade name, trademark, manufacturer, or otherwise does not necessarily constitute or imply its endorsement, recommendation, or favoring by the United States Government or any agency thereof. The views and opinions of authors expressed herein do not necessarily state or reflect those of the United States Government or any agency thereof.

Although this product represents the work of professional scientists, the Utah Department of Natural Resources, Utah Geological Survey, makes no warranty, express or implied, regarding its suitability for a particular use. The Utah Department of Natural Resources, Utah Geological Survey, shall not be liable under any circumstances for any direct, indirect, special, incidental, or consequential damages with respect to claims by users of this product. 


\begin{abstract}
Maps showing potential mercury, sulfur, chlorine, and moisture emissions for U.S. coal by county of origin were made from publicly available data (plates 1, 2, 3, and 4). Published equations that predict mercury capture by emission control technologies used at U.S. coal-fired utilities were applied to average coal quality values for 169 U.S. counties. The results were used to create five maps that show the influence of coal origin on mercury emissions from utility units with: (1) hot-side electrostatic precipitator (hESP), (2) cold-side electrostatic precipitator (cESP), (3) hot-side electrostatic precipitator with wet flue gas desulphurization (hESP/FGD), (4) coldside electrostatic precipitator with wet flue gas desulphurization (cESP/FGD), and (5) spray-dry adsorption with fabric filter (SDA/FF) emission controls (plates 5, 6, 7, 8, and 9). Net (lower) coal heating values were calculated from measured coal Btu values, and estimated coal moisture and hydrogen values; the net heating values were used to derive mercury emission rates on an electric output basis (plate 10).

Results indicate that selection of low-mercury coal is a good mercury control option for plants having hESP, cESP, or hESP/FGD emission controls. Chlorine content is more important for plants having cESP/FGD or SDA/FF controls; optimum mercury capture is indicated where chlorine is between 500 and 1000 ppm. Selection of low-sulfur coal should improve mercury capture where carbon in fly ash is used to reduce mercury emissions. Comparison of in-ground coal quality with the quality of commercially mined coal indicates that existing coal mining and coal washing practice results in a $25 \%$ reduction of mercury in U.S. coal before it is delivered to the power plant. Further pre-combustion mercury reductions may be possible, especially for coal from Texas, Ohio, parts of Pennsylvania and much of the western U.S.
\end{abstract}




\section{CONTENTS}

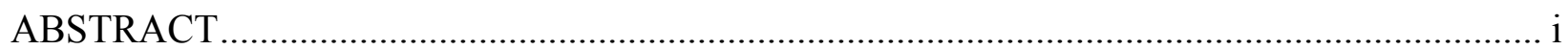

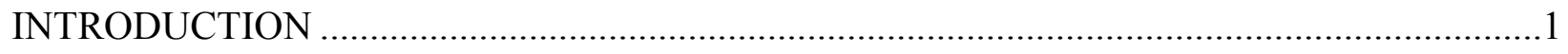

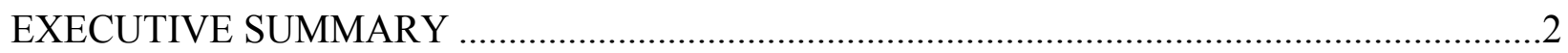

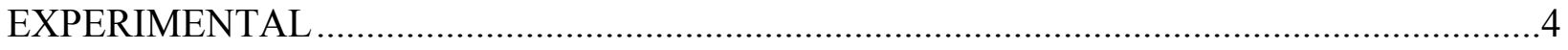

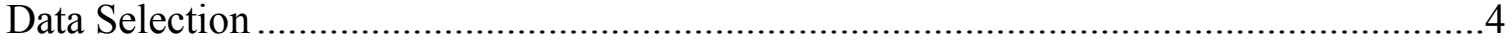

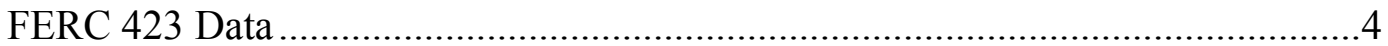

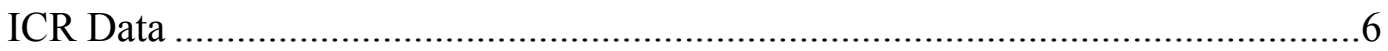

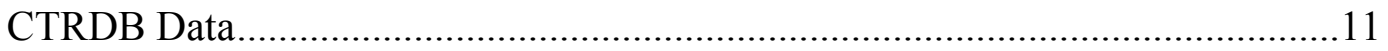

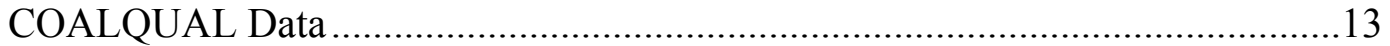

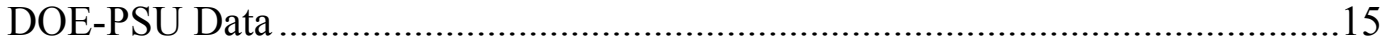

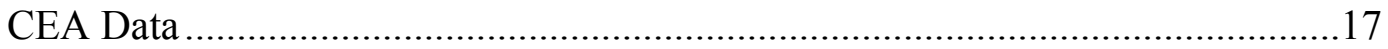

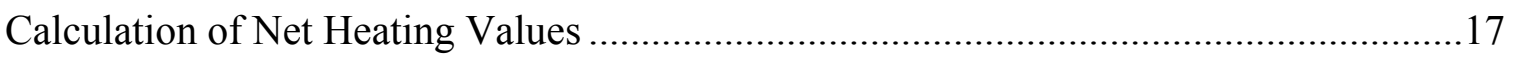

Estimating Moisture .....................................................................................19

Verification of Estimated Moisture Values ..........................................................22

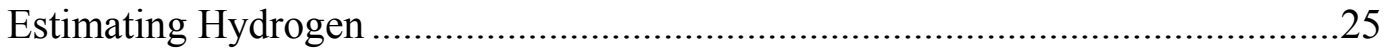

Verification of Estimated Hydrogen Values ........................................................30

Verification of ICR Net Heating Values........................................................................32

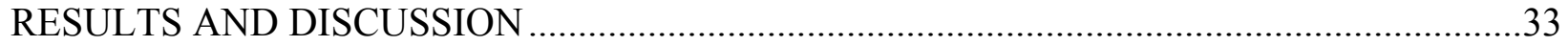

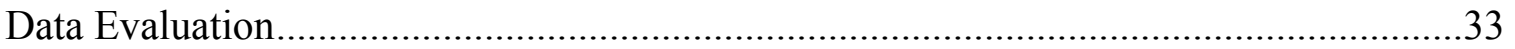

Mercury Capture by Existing Emission Controls ...............................................................42

Selecting the Best Equation to Predict Mercury Capture ...................................................58

Comparison of Existing Technologies: Implications for Mercury Control ........................59

The Relationship Between Coal Sulfur and Mercury Capture ...........................................61

In-Ground Coal Mercury Compared to Commercial Coal Mercury ....................................64

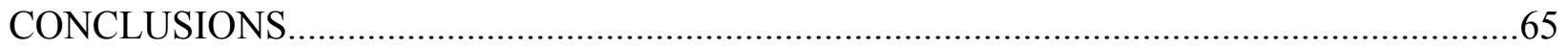

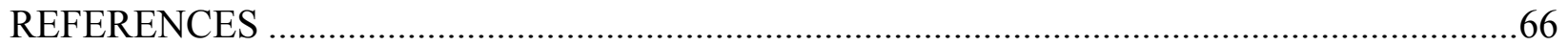

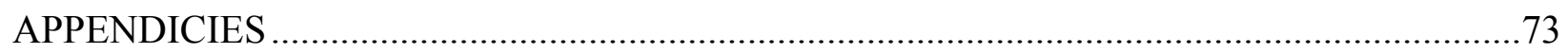

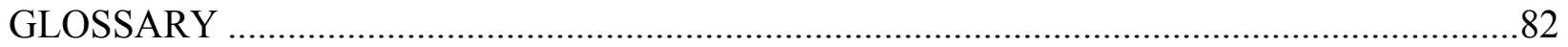

\section{FIGURES}

Figure 1. Geographic distribution of selected FERC 423 data by U.S. county-of-origin...............4

Figure 2. Geographic distribution of selected ICR data records, by U.S. county-of-origin ...........7

Figure 3. Geographic distribution of selected CTRDB data by U.S. county-of-origin ................11

Figure 4. Geographic distribution of selected COALQUAL data records ..................................13 
Figure 5. Geographic distribution of selected DOE-PSU data records 16

Figure 6. Emissions expressed on an output basis are better estimated if the fuel emission factor is expressed on a net energy basis rather than on a gross energy basis. .18

Figure 7. Illustration of the method used to estimate ICR moisture values. .20

Figure 8. The estimated ICR moisture values are nearly the same as the observed CTRDB moisture values

Figure 9. The essentially identical relationship between the coal heating value and coal moisture content for the ICR and CTRDB data. .24

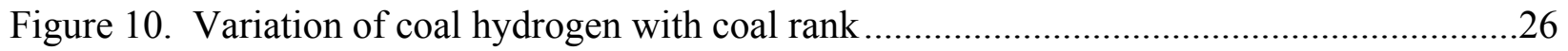

Figure 11. COALQUAL moisture values are lower than moisture values for other data sets .....27

Figure 12. Regression equations to predict coal hydrogen content were developed for nine, coal-producing regional groups

Figure 13. A near 1:1 relationship is observed between the measured PSU-DOE hydrogen values and predicted PSU-DOE hydrogen values

Figure 14. The difference between the net and gross heating value of U.S. coal from two data sets systematically varies with ASTM (1990) coal rank

Figure 15. Histograms showing the distribution of county-average coal quality values for the COALQUAL, FERC 423, ICR, and CTRDB data sets

Figure 16. Cross-plots comparing the county-average moisture, ash, sulfur, and Btu values from the ICR data set with those from the CTRDB, COALQUAL, and FERC 423 data sets

Figure 17. Distribution of county-average, mercury, chlorine and sulfur values for in-ground coal and commercial coal.

Figure 18. Comparison of mercury, chlorine, and sulfur values in the ICR and COALQUAL data sets. .38

Figure 19. The difference between the mercury content of in-ground coal and the mercury content of mined coal varies geographically

Figure 20. Average chlorine content of coal delivered to U.S. power plants during 1999, by county-of-origin

Figure 21. Three equations predict different amounts of mercury capture for SDA/FF technology

Figure 22. Three equations predict different amounts of mercury capture for cESP/FGD technology.....

Figure 23. Three equations predict different amounts of mercury capture for hESP/FGD technology.

Figure 24. Three equations predict different amounts of mercury capture for cESP technology. 
Figure 25. Three equations predict different amounts of mercury capture for hESP technology.

Figure 26. Mercury capture predicted for 162 U.S. counties increases with increasing coal chlorine for five existing control technologies ......

Figure 27. Potential uncontrolled sulfur emissions from coal by U.S. county-of-origin .48

Figure 28. Potential uncontrolled mercury emissions from coal by U.S. county-of-origin 49

Figure 29. Potential uncontrolled chlorine emissions from coal by U.S. county-of-origin .50

Figure 30. Predicted mercury emissions for coal burned in electric utilities with Hot-Side Electrostatic Precipitators

Figure 31. Predicted mercury emissions for coal burned in electric utilities with Cold-Side Electrostatic Precipitators

Figure 32. Predicted mercury emissions for coal burned in electric utilities with Hot-Side Electrostatic Precipitators and wet Flue Gas Desulphurization controls

Figure 33. Predicted mercury emissions for coal burned in electric utilities with Cold-Side, Electrostatic Precipitators and wet Flue Gas Desulphurization controls.

Figure 34. Predicted mercury emissions by U.S. county-of-origin for coal burned in electric utilities with Spray-Dry Adsorption and Fabric Filter controls

Figure 35. Predicted mercury emission rate (lbs $\mathrm{Hg} \times 10^{-6} /$ megawatt-hour) for coal burned in electric utilities with Cold-Side, Electrostatic Precipitators and wet Flue Gas Desulphurization controls

Figure 36. Predicted mercury emission rate (lbs $\mathrm{Hg} \mathrm{x} 10^{-6} /$ megawatt-hour) for coal burned in electric utilities with Spray-Dry Adsorption and Fabric Filter controls 57

Figure 37. Decreasing mercury capture with increasing coal sulfur .63

\section{PLATES}

Plate 1. Mercury in commercial U.S. coal in pocket

Plate 2. Sulfur in commercial U.S. coal in pocket

Plate 3. Chlorine in commercial U.S. coal in pocket

Plate 4. Moisture in commercial U.S. coal in pocket

Plate 5. Mercury emissions from U.S. coal predicted for utilities with hot-side electrostatic precipitators in pocket

Plate 6. Mercury emissions from U.S. coal predicted for utilities with cold-side electrostatic precipitators in pocket

Plate 7. Mercury emissions from U.S. coal predicted for utilities with hot-side electrostatic precipitators with wet flue gas desulphurization in pocket 
Plate 8. Mercury emissions from U.S. coal predicted for utilities with cold-side electrostatic precipitators with wet flue gas desulphurization in pocket

Plate 9. Mercury emissions predicted for utilities with spray-dry adsorption and fabric filters in pocket

Plate 10. Potential mercury emission rate of commercial U.S. coal (no capture electric output basis. in pocket

\section{TABLES}

Table 1. List of data fields in the 1999, FERC 423 Data.........................................................5

Table 2. Tabulation of selected and ignored 1999, FERC 423 data records ..............................5

Table 3. Summary of data fields in the 1999, ICR data........................................................... 8

Table 4. Tabulation of selected and ignored data records for the 1999, ICR data......................9

Table 5. Coal production from counties not represented in the ICR data selected for this

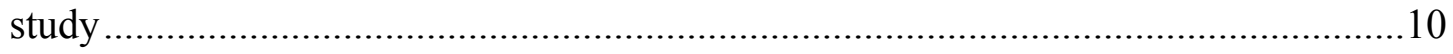

Table 6. Summary of data fields in the 1992-1999, CTRDB data .........................................12

Table 7. Tabulation of selected and ignored data records for the 1992-1999, CTRDB data.......12

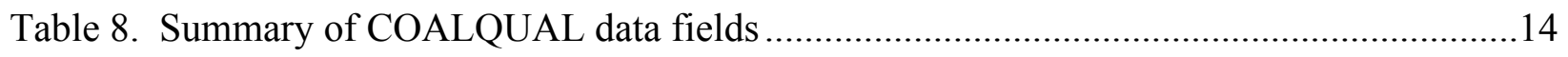

Table 9. Tabulation of selected and ignored COALQUAL data records ................................15

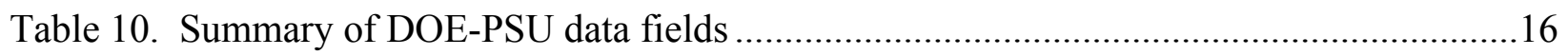

Table 11. CAMR standards of performance for new coal-fired power plants...........................18

Table 12. Equations used to estimate regional ash vs. Btu intercept values for FERC 423

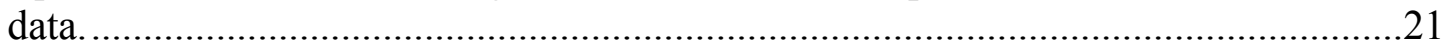

Table 13. List of variables, coefficients, and statistics for geographically specific regression equations used to predict the hydrogen content of coal ......................................... 31

Table 14. Technology-specific equations that predict mercury capture ..................................43

Table 15. Comparison of mercury control technologies..........................................................60 


\section{INTRODUCTION}

Switching to low-mercury-emission coal may be an effective strategy to comply with the new Clean Air Mercury Rule (CAMR; USEPA, 2005), which is intended to reduce U.S. mercury emissions from electric utilities. For example, despite proven emission control technology, burning low-sulfur coal is the most popular method to reduce sulfur emissions. Because technology to reduce mercury emissions is less certain, burning low-mercury coal is a likely method to reduce mercury emissions. Like sulfur, the amount of mercury in U.S. coal shows substantial geographic variation. However, unlike sulfur, mercury emissions also vary with the abundance of other elements in the coal, such as chlorine and sulfur, which influence mercury capture by emission control technologies. Moreover, empirical equations indicate that the ability of these elements to promote or inhibit mercury capture categorically varies among existing emission control technologies (Chu and others, 2000).

This project uses Geographic Information System technology (ArcView GIS) to create maps that show where U.S. coal with low-mercury and acid-gas emissions might be found. The map series shows geographic variation of mercury, chlorine, and sulfur in coal, as well as the mercury emission penalty, calculated for data aggregated by U.S. county-of-origin using equations specific to power plants classified by boiler type and flue gas emission controls. Removing mercury from flue gas is a technically complex task - different technologies will be required for different coals. Maps showing the geographic variation of mercury and acid-gas emission factors for U.S. coal will help locate the best coal for each technology and identify the best technology for each coal. 


\section{EXECUTIVE SUMMARY}

Coal quality data used in this study were selected from public data sets and include: 19,493 FERC 423 data records (USEIA, 2003a), 27,006 ICR data records (USEPA, 2003), 5823 CTRDB data records (USEIA, 2003b), 5059 COALQUAL data records (Bragg and others, 1997), and 73 PSU-DOE data records (Anonymous, 1990; Davis and Glick, 1993; Scaroni and others, 1999). Additional data considered in this report are from CEA (2004) and USMSHA (2004).

Native mercury capture by existing emission control technologies can be evaluated using the ICR part 3 data set (USEPA, 2003), which includes measurements of mercury in boiler flue gas as well as mercury stack emissions from about 80 U.S coal-fired boilers. We examined a variety of published equations derived from the ICR 3 data that predict mercury capture from fuel mercury, chlorine, sulfur and heating values. Ultimately, equations from SAIC (2003), Roberson (2002), or ENSR (2003) were chosen to predict mercury capture by five common emission control technologies. Using county-specific coal quality data and technology-specific mercury emission factors obtained from these equations, we made maps showing the expected mercury emissions by coal origin for pulverized-coal-fired electric generating units with (1) hotside electrostatic precipitator [hESP], (2) cold-side electrostatic precipitator [cESP], (3) hot-side electrostatic precipitator / wet flue-gas desulfurization [hESP/FGD], (4) cold-side electrostatic precipitator / wet flue-gas desulfurization [cESP/FGD], and (5) spray-dry adsorption / fabric filter [SDA/FF] emission controls. The map series shows mercury emission on both a fuel-input basis (lbs $\left.\mathrm{Hg} / 10^{12} \mathrm{Btu}\right)$ and an electric-output basis (lbs x $10^{-6} \mathrm{Hg} / \mathrm{MWh}$ ), as well as geographic variation of coal sulfur, chlorine, and moisture content. 
A tonnage-weighted comparison of in-ground coal mercury concentrations with coal mercury concentrations in commercially produced coal showed that U.S. coal shipped to utilities during 1999 contained $8.3 \mathrm{lbs} \mathrm{Hg} / 10^{12}$ Btu whereas the actively-mined, in-ground coal contained about $11 \mathrm{lbs} \mathrm{Hg} / 10^{12}$ Btu. The $25 \%$ reduction of mercury in commercially mined coal is attributed to selective mining of low mercury coal and mercury reductions due to coal washing. However, this difference is not geographically uniform. Finally, empirical data from the Canadian Electricity Association (CEA, 2004) were used to evaluate the negative correlation between coal sulfur content and mercury capture.

Significant findings include:

- Selection of low-mercury coal is a reasonable way to reduce mercury emissions from units equipped with hESP, cESP, or hESP/FGD controls, whereas selection of coal with highchlorine content is a better option for units with cESP/FGD, or SDA/FF controls.

- Coal selection or blending to an optimum level between 500 and 1000 ppm chlorine could reduce mercury emissions for units with cESP/FGD, or SDA/FF controls.

- Although coal shipped to utilities contains about 25\% less mercury than the in-ground resource, this difference is not geographically uniform. With the notable exception of Powder River Basin (PRB) coal from Wyoming, the mercury content of commercial coal from the western U.S., Ohio, northern Pennsylvania, and the Gulf Coast, is similar to or greater than that in the in-ground coal resource. Coal washing or selective mining might be an effective mercury mitigation strategy in these areas.

- Selection of low-sulfur coal may improve mercury capture where carbon in fly ash is used to reduce mercury emissions. 


\section{EXPERIMENTAL}

\section{Data Selection}

Coal quality data were selected from five public data sets, which are identified in this report as the FERC 423, ICR, CTRDB, COALQUAL, PSU-DOE, and CEA data sets. Notably, most of these data are available online.

\section{FERC 423 Data}

Figure 1 shows the geographic distribution of the 19,493 records selected from the 35,887 records listed in the 1999, FERC 423 data set (USEIA, 2003a). The FERC 423 data are from the Form 423 monthly survey of fossil-fueled electric utilities collected by the Federal Energy Regulatory Commission (FERC). Among other things, the records list the cost, quality, and origin of fuel shipments delivered to electric utility power plants with steam generator capacities of at least 50 MW. Data fields listed in the FERC 423 are described in table 1.

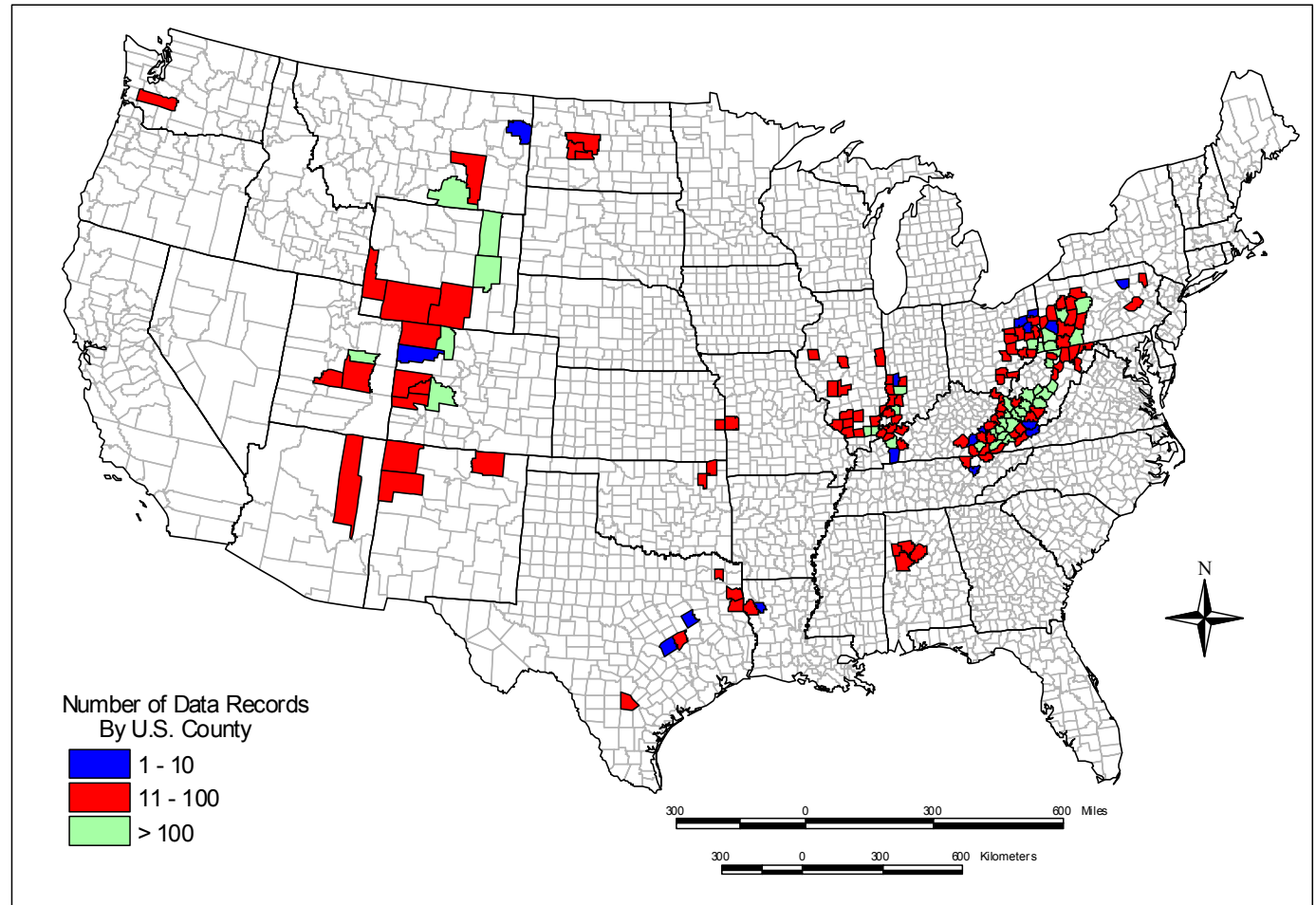

Figure 1. Geographic distribution of selected FERC 423 data by U.S. county-of-origin. 
Table 1. List of data fields in the 1999, FERC 423 Data.

\begin{tabular}{ll}
\hline Company & Code for the name of utility parent company. \\
Plant & Code for the name of the utility power plant. \\
Year & Reporting year. \\
Month & Reporting month. \\
BOM District & U.S. Bureau of Mines coal producing district, country-of-origin (coal only). \\
State-of-origin & U.S. state-of-origin (coal). \\
Mine Type & Surface or underground coal mine. \\
Region (plant) & Regional location of the electric utility. \\
State (plant) & State location of the electric utility. \\
Generic Fuel & Type of fuel (solid, liquid, gaseous). \\
Specific Fuel & Bituminous, subbituminous, lignite, fuel oil, natural gas, etc. \\
Contract Type & Simple contract, contract with escalator, new, firm (gas), interruptible gas, \\
& spot and off peak gas, spot coal, or spot oil. \\
Contract Expire & Indicates if the contact expires within 24 months. \\
Quantity & Tons in coal shipment (short tons). \\
Btu & Heating value (gross Btu/lb, as-shipped). \\
Sulfur & Sulfur content (weight\%, as-shipped). \\
Ash & Ash value (weight\%, as-shipped). \\
Cost & Cents per million Btu (total cost, including transportation and taxes). \\
County & U.S. county-of-origin (mostly for coal shipments). \\
\hline
\end{tabular}

Table 2 shows that about half of the FERC 423 data records are selected for this project.

Records for liquid, gaseous, and other non-coal fuels are ignored, as are records for imported coal and domestic coal of uncertain state or county origin.

Table 2. Tabulation of selected and ignored 1999, FERC 423 data records.

\begin{tabular}{|c|c|c|}
\hline 35,886 & ORIGINAL REC & ORDS \\
\hline & 15,790 & Liquid or gas ${ }^{1}$ \\
\hline & 20,096 & Solid fuel \\
\hline 20,096 & SOLID FUEL R & ECORDS \\
\hline & 116 & Imported coal $^{1}$ \\
\hline & 146 & Uncertain location ${ }^{1}$ \\
\hline & 231 & Petroleum coke $^{1}$ \\
\hline & 68 & Refuse $^{1}$ \\
\hline & 42 & Wood $^{1}$ \\
\hline & 19,493 & Coal \\
\hline 19,493 & SELECTED RE & CORDS \\
\hline & 20 & Anthracite \\
\hline & 15,948 & Bituminous \\
\hline & 235 & Lignite \\
\hline & 3,290 & Subbituminous \\
\hline
\end{tabular}

\footnotetext{
${ }^{1}$ ignored.
} 
Although fuel receipts reported on the FERC Form 423 include over 99\% of coal delivered to electric utility power plants, non-utility power plants (independent power producers and combined heat and power plants) do not report on FERC Form 423. These non-utility power plants consumed 56 million tons of coal during 1999, which is about five percent of the total 950 million tons burned at power plants (USEIA 2003c). Consequently, the FERC 423 data are missing about five percent of the coal tonnage shipped to electric power plants during 1999.

\section{ICR Data}

The ICR coal quality data set includes 152,476 records, which are available in four quarterly data files on a U.S. Environmental Protection Agency website (USEPA, 2003). Figure 2 shows the geographic distribution of the 27,006 records selected from this data set. The ICR data originate from the Information Collection Request (part 2) issued by the EPA. The EPA required electric utility steam generating units of $25 \mathrm{MW}$ or more to report coal origin, tonnage, and assay values for every solid fuel shipment received during 1999, and to periodically measure and report the mercury and chlorine values for these shipments. The U.S. Geological Survey (USGS) added some data fields in June 2002 to indicate (where possible) consistent names for the coal bed, mine, field, and other attributes. Data fields listed in the ICR data are summarized in table 3. Notably, the ICR assay values are reported on a dry basis, and include mercury and chlorine values.

Of the 152,476 ICR data records, only 26,007 (17\%) are used in this project (table 4). Most of the ignored records lack mercury assay values. Records corresponding to coal waste products, coal blends, or non-coal fuels are also ignored. Of the remaining records for single coals that include mercury values, over five thousand are not used because they lack location origins. In some instances, it was possible to infer location origins. For example, 85 ICR data 
records originating from the Martin Lake power station (but lacking county-of-origin information) were assigned to Panola and Rusk Counties, Texas. Likewise, 87 records from the Monticello station were assigned to Titus County, Texas. Notably, the Monticello records may include coal originating from nearby Hopkins County, Texas. Similarly, examination of coal supplier names identified nine records for coal from Washington County, Illinois, and seven records from Schuylkill County, Pennsylvania. With the exception of samples from mine-mouth power plants, records listed as grab samples or as-fired samples are also ignored; these sample collection methods tend to result in biased or non-representative assay specimens. Finally, several hundred records for samples from outside the study area are also ignored.

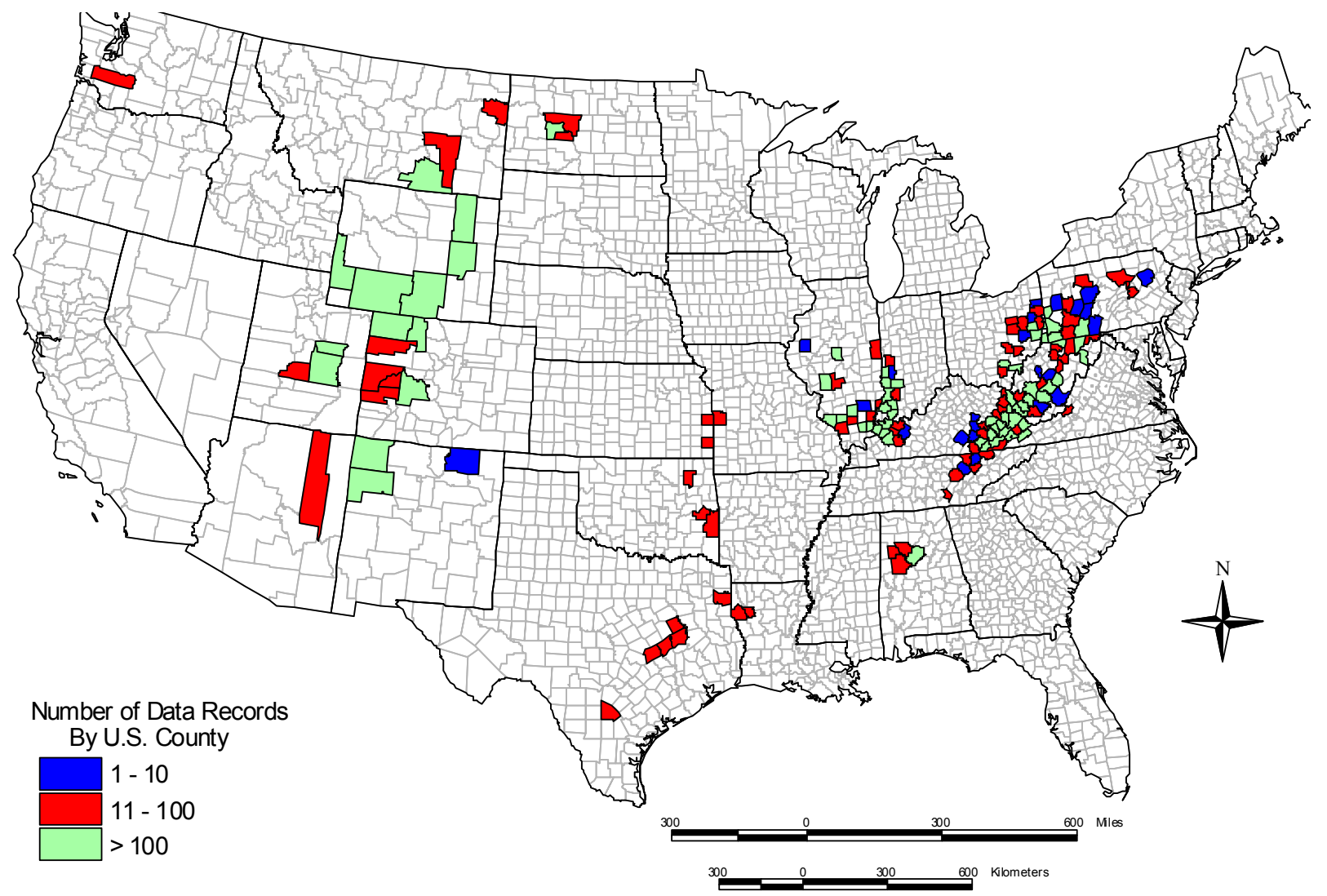

Figure 2. Geographic distribution of selected ICR data records, by U.S. county-of-origin. 
Table 3. Summary of data fields in the 1999, ICR data.

\begin{tabular}{|c|c|}
\hline Plant Name & The name of the power plant. \\
\hline Shipment date & The date of the coal shipment. \\
\hline Received & The amount of the shipment in dry tons. \\
\hline State & The shipment State-of-origin. \\
\hline County & The shipment county-of-origin. \\
\hline Seam & The coal bed name reported by the power plant. \\
\hline Method & The shipment transportation mode. \\
\hline Fuel Type & The kind of fuel. \\
\hline Supplier & The supplier name, location, and address. \\
\hline Amount & The amount of the shipment that the assay represents in dry tons. \\
\hline Sulfur & Sulfur content (weight\%, dry basis). \\
\hline Btu & Heating value (gross Btu/lb, dry basis). \\
\hline Ash & Ash value (weight\%, dry basis). \\
\hline Mercury & $\begin{array}{l}\text { Mercury content (ppm, dry basis) where results below the detection limit } \\
\text { are flagged. }\end{array}$ \\
\hline Chlorine & $\begin{array}{l}\text { Chlorine content (ppm, dry basis) where results below the detection limit } \\
\text { are flagged. }\end{array}$ \\
\hline $\begin{array}{l}\text { Assay } \\
\text { Methods }\end{array}$ & $\begin{array}{l}\text { Including reference to standard or in-house methods used to collect, } \\
\text { prepare, and measure mercury in assay specimens, with an indication of } \\
\text { assay accuracy and precision. }\end{array}$ \\
\hline Laboratory & The name, location and address of the laboratory. \\
\hline Coal Bed & USGS ${ }^{1}$ Coal Bed. \\
\hline Coal Group & USGS ${ }^{1}$ Coal Group. \\
\hline Coal Zone & $\begin{array}{l}\text { USGS }{ }^{1} \text { National Coal Resource Investigations and Assessments coal bed } \\
\text { zone. }\end{array}$ \\
\hline Coal Basin & USGS ${ }^{1}$ Coal basin or field. \\
\hline Coalfield & USGS ${ }^{1}$ Local coalfield name. \\
\hline Coal Mine & USGS ${ }^{1}$ Coal mine name. \\
\hline
\end{tabular}

${ }^{1}$ United States Geological Survey, added June 2002.

Quick and others (2003) used a graph of ash verses the heating value (Btu) for coal from Campbell County, Wyoming to identify erroneous ICR assay data. This graphic method, when applied to each of the 169 U.S. counties represented in the ICR, shows 2852 erroneous data records (table 4). Most (73\%) of the erroneous records are attributed to incorrect reporting bases where assay results are data reported on a moist basis, or on a dry ash-free basis, rather than the dry basis specified by the ICR. In a few instances it was possible to identify mistaken location origins. No cause is known for the remaining erroneous records. Possible causes include data 
entry errors, mistaken location origins, unrecognized coal blends, and analytical error; these data were ignored.

Table 4. Tabulation of selected and ignored data records for the 1999, ICR data.

152,476 ORIGINAL RECORDS

103,403 Coal without $\mathrm{Hg}$ or $\mathrm{Cl}$ values ${ }^{1}$

4,361 Coal waste $^{1}$

3,283 Coal blends ${ }^{1}$

3,256 Petroleum coke ${ }^{1}$

1,045 Tire derived fuel ${ }^{1}$

37,128 RECORDS FOR COAL WITH MERCURY VALUES

5,351 Coal without state or county locations ${ }^{1}$

1,005 As-fired samples ${ }^{1}$

763 Apparent duplicate records ${ }^{1}$

697 Apparent nominal data ${ }^{1}$

348 Foreign coal $^{1}$

70 Grab samples ${ }^{1}$

35 Alaskan coal $^{1}$

28,859 INITIAL RECORDS

2,852 Data outliers ${ }^{1}$, including:

1,363 on a dry, ash-free basis ${ }^{1}$

713 on a moist basis ${ }^{1}$

90 with bad location origins ${ }^{1}$, and

686 of undetermined cause ${ }^{1}$

26,007 SELECTED RECORDS

1 ignored.

Comments to the USEPA related to the proposed mercury reduction rule (McCall, 2004;

Eutizi, 2005; Glacken, 2005) suggest that the mercury values reported in the ICR data for most

Gulf Coast coal are erroneously low. Accordingly, average mercury values, from ICR part 3

testing $^{1}$ or newly reported values (McCall, 2004; Eutizi, 2005), were used to estimate county-

average mercury values for coal from Panola, Titus, Atascosa, Freestone, Milam, and Robertson

Counties, Texas. Mercury values for Leon County, Texas, as well as Red River and De Soto

Parishes, Louisiana, have not been revised and may be too low.

\footnotetext{
${ }^{1}$ The ICR part 3 data originate from measurements of atmospheric mercury emissions from about 80 selected U.S. power plants (USEPA, 2003). The data show measured mercury emissions and mercury capture observed during three, multiple hour intervals for each plant, and are complementary to the more comprehensive ICR coal assay data.
} 
Comparison of ICR county origins, with 1999 county coal production (USEIA 2000;

USMSHA, 2004) showed that not all coal-producing counties are represented in the ICR data.

Table 5 lists the counties missing from the selected ICR data, together with their 1999 coal

production. The missing counties represent 15.7 million tons, which is less than $2 \%$ of 1999

U.S. coal production.

Table 5. Coal production from counties not represented in the ICR data selected for this study.

\begin{tabular}{|c|c|c|}
\hline State & County & 1999 production (tons) \\
\hline Alabama & Bibb & 44,500 \\
\hline Alabama & Cullman & 35,700 \\
\hline Alabama & Marion & 35,700 \\
\hline Alabama & Winston & 338,500 \\
\hline Arkansas & Johnson & 14,600 \\
\hline Colorado & Fremont & 242,200 \\
\hline Colorado & La Plata & 245,700 \\
\hline Illinois & Christian & 72,200 \\
\hline Indiana & Dubois & 72,800 \\
\hline Indiana & Spencer & 204,400 \\
\hline Kentucky & Knox & 506,100 \\
\hline Mississippi & Choctaw & 18,400 \\
\hline Missouri & Barton & 73,000 \\
\hline Ohio & Gallia & 220,600 \\
\hline Ohio & Monroe & 489,600 \\
\hline Ohio & Muskingum & 663,100 \\
\hline Ohio & Noble & 689,800 \\
\hline Ohio & Stark & 316,400 \\
\hline Oklahoma & Craig & 194,100 \\
\hline Pennsylvania & Carbon & 39,300 \\
\hline Pennsylvania & Clarion & 418,100 \\
\hline Pennsylvania & Jefferson & $1,119,100$ \\
\hline Pennsylvania & Lawrence & 84,800 \\
\hline Pennsylvania & Sullivan & 47,100 \\
\hline Pennsylvania & Venango & 91,600 \\
\hline Texas & Hopkins & $2,126,100$ \\
\hline Texas & Webb & 235,000 \\
\hline Virginia & Tazewell & $2,062,700$ \\
\hline West Virginia & McDowell & $4,698,900$ \\
\hline West Virginia & Mineral & 48,500 \\
\hline West Virginia & Tucker & 172,423 \\
\hline Wyoming & Sheridan & 76,400 \\
\hline
\end{tabular}




\section{CTRDB Data}

The CTRDB data set is from the U.S. Energy Information Administration (USEIA, 2003b). It contains 7905 records for certain commercial coal shipments delivered to power plants between 1992 and 1999. Figure 3 shows the geographic distribution of the 5823 selected CTRDB data records. The CTRDB acronym is an abbreviation for the Coal Transportation Rate Data Base. The data largely originate from the FERC Form 580, biannual survey of investorowned, interstate electric power plants. Among other things, the records list the quality and origin of contract fuels delivered to steam-electric power plants of $50 \mathrm{MW}$ or more. Data fields listed in the CTRDB data set are summarized in table 6. Note that the CTRDB data fields include coal moisture values; these moisture values are used to verify moisture values estimated for ICR coal (discussed below).

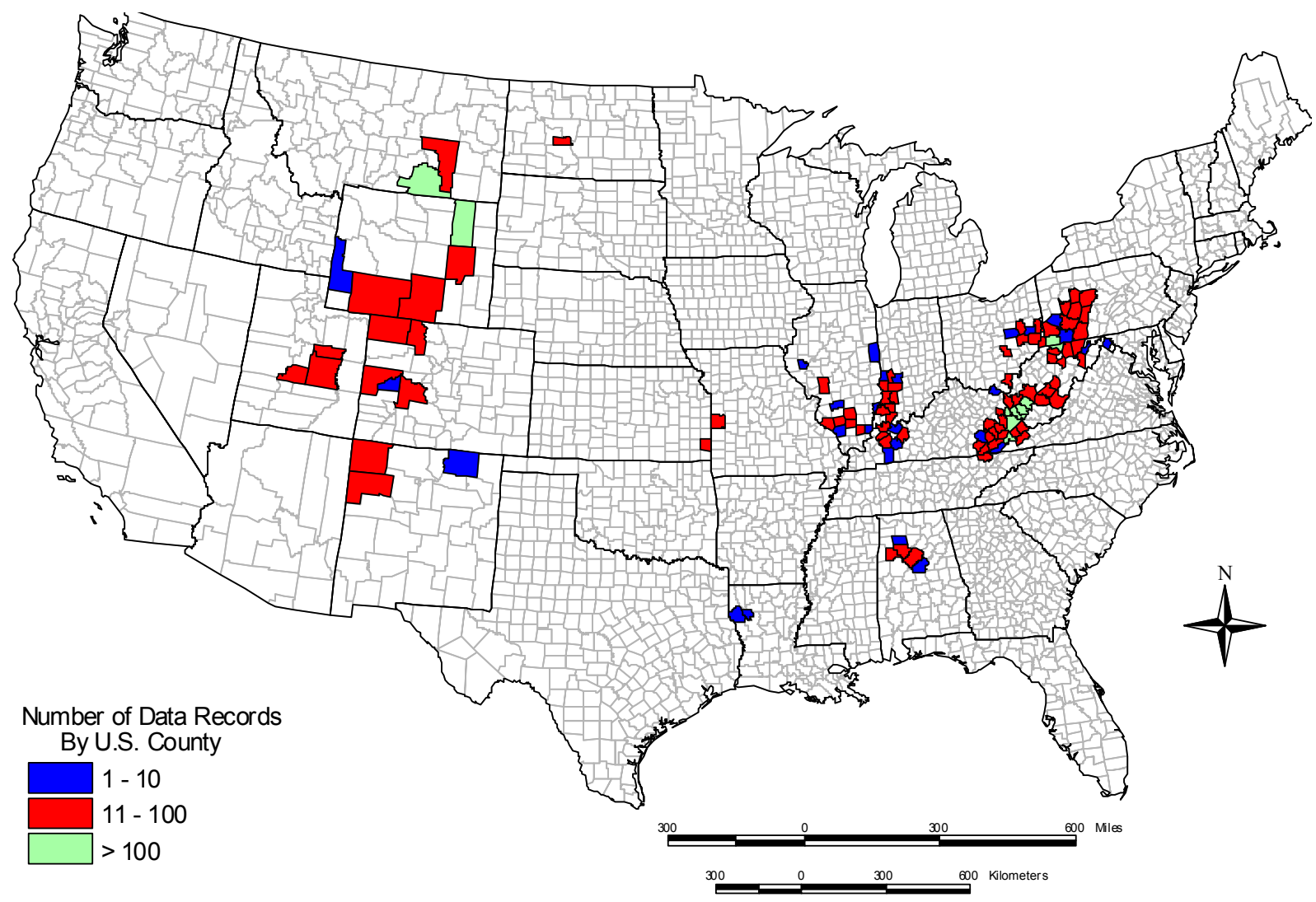

Figure 3. Geographic distribution of selected CTRDB data by U.S. county-of-origin. 
Table 6. Summary of data fields in the 1992-1999, CTRDB data.

\begin{tabular}{ll} 
Utility Name & Name of the utility parent company. \\
Year & The year the data represent. \\
Contract Specifications & Including: contracted dates, tonnage, and coal quality specifications. \\
Contractor Name & Name of the coal supplier. \\
Mine Name & Name of the coal mine. \\
Origin State & State of the coal origin. \\
Origin County & County of the coal origin. \\
BOM District & Bureau of Mines coal-producing district of the coal origin. \\
Destination Plant & Power plant name. \\
Destination State & Location state of the power plant. \\
Destination County & Location county of the power plant. \\
Tons Shipped & Tons of coal shipped. \\
Mine Price & Price of the coal at the coal mine. \\
Delivered Price & Price of the coal at the power plant. \\
Btu & Coal heating value (gross Btu/lb, as-shipped). \\
Sulfur & Coal sulfur content (weight\%, as-shipped). \\
Ash & Coal ash value (weight\%, as-shipped). \\
Moisture & Coal moisture content (weight\%, as-shipped). \\
Transportation & Type of transportation (train, truck, barge, etc); the number of transport \\
Information & modes, carriers, and transfers; transport distance. \\
Carrier Information & Name(s) of transport carriers, transfer locations etc. \\
Transport Costs & Mode rates, transfer fees, and so forth. \\
\hline
\end{tabular}

About three-fourths of the records included in the CTRDB are selected for use in this project (table 7). Records corresponding to duplicate assays are most frequently ignored; this is done to preclude weighting effects in subsequent analyses. Records that lack coal quality values or location origins, as well those for coke or imported coal, are also ignored. Finally, a few records with anomalous coal quality values (outliers on Btu vs. moisture plots) are also ignored.

Table 7. Tabulation of selected and ignored data records for the 1992-1999, CTRDB data.

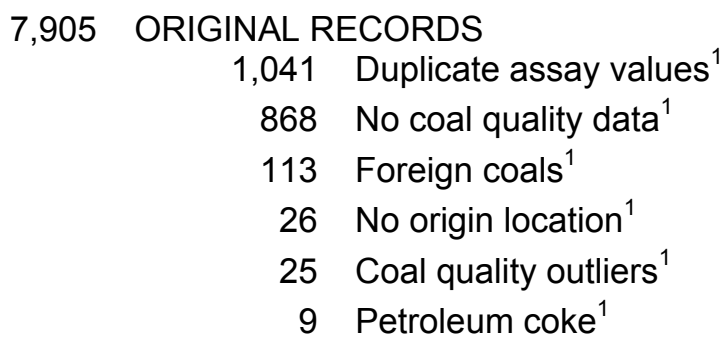




\section{COALQUAL Data}

The COALQUAL data set (Bragg and others, 1997) contain 7432 records for coal samples collected from U.S. drill holes, mines, and outcrops. Figure 4 shows the geographic distribution of the 5059 selected COALQUAL data records. Up to 136 data fields listing the sample type, location, and assay results are included for each record. Nearly all records have complete proximate and ultimate assays as well as major, minor, and trace element values. Data fields listed in the COALQUAL data are summarized in table 8.

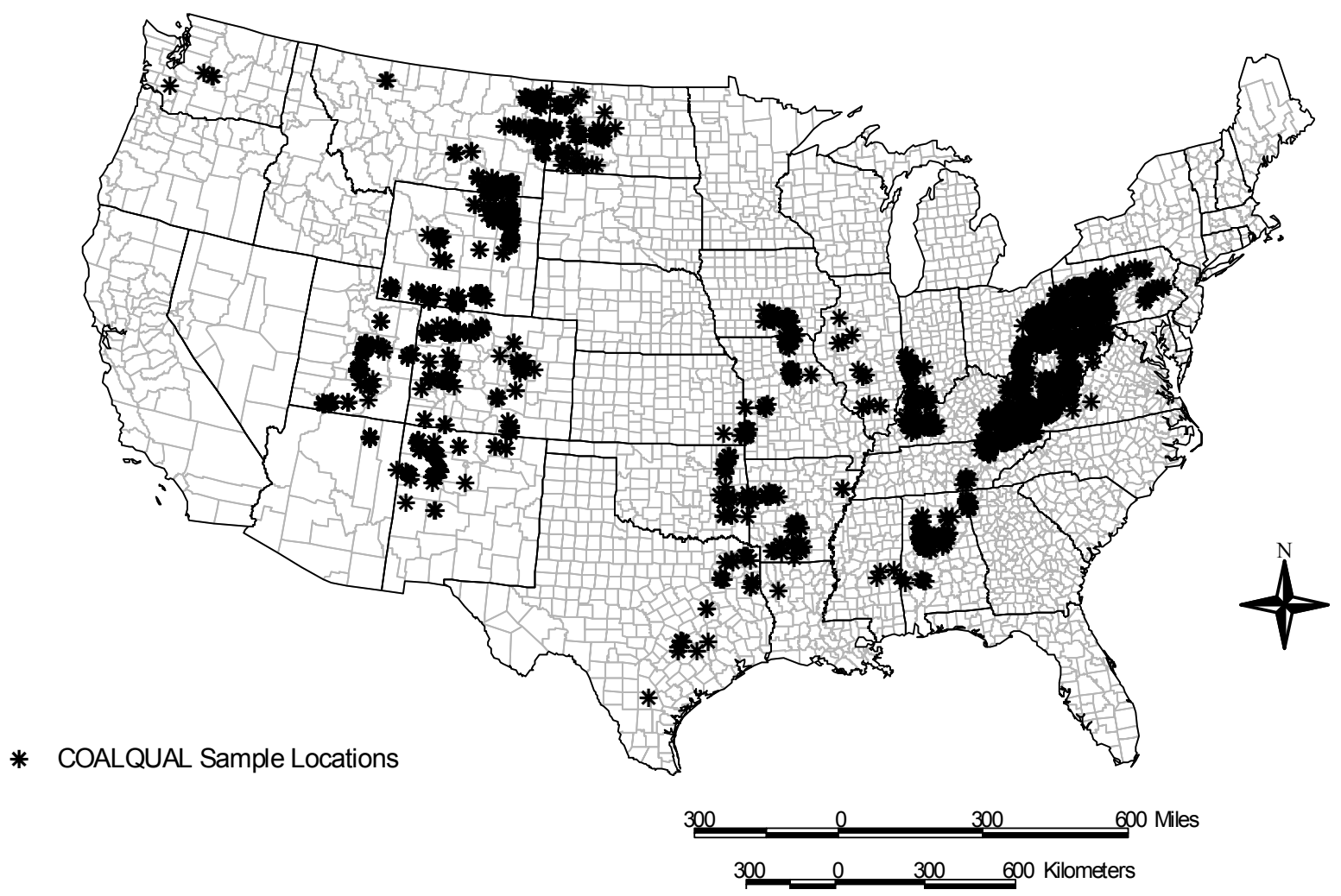

Figure 4. Geographic distribution of selected COALQUAL data records. 
Table 8. Summary of COALQUAL data fields.

\begin{tabular}{|c|c|}
\hline $\begin{array}{l}\text { Location } \\
\text { Information }\end{array}$ & $\begin{array}{l}\text { Including: state, county, latitude, longitude, province, region, field, district, } \\
\text { quadrangle. }\end{array}$ \\
\hline $\begin{array}{l}\text { Geologic } \\
\text { Information }\end{array}$ & $\begin{array}{l}\text { Including: formation, group, bed, member, zone, depth, bed thickness, } \\
\text { system, and geologic age. }\end{array}$ \\
\hline $\begin{array}{l}\text { Collection } \\
\text { Information }\end{array}$ & $\begin{array}{l}\text { Collector name, drillhole/mine name, estimated rank, and laboratory } \\
\text { submission date. }\end{array}$ \\
\hline Laboratory & $\begin{array}{l}\text { Assay laboratory: U.S. Bureau of Mines, Geochemical Testing Co., State } \\
\text { agencies, USGS, Dickinson Laboratories Inc. }\end{array}$ \\
\hline Sample Type & Channel, drillcore, weathered channel, or outcrop. \\
\hline Data Type & $\begin{array}{l}\text { Single sample assay, physical composite assay, calculated composite } \\
\text { assay, partial composite assay, partial bed split. }\end{array}$ \\
\hline ASTM $^{1}$ Assays & $\begin{array}{l}\text { (Moist, whole-coal basis) including: moisture, Btu, ash, volatile matter, } \\
\text { CHNOS, }{ }^{2} \text { ash fusion temperatures, free swelling index, sulfur forms, air-dry- } \\
\text { loss, equilibrium moisture, and Hardgrove grindability. }\end{array}$ \\
\hline USGS Assays & $\begin{array}{l}\text { (Residual moisture basis) including: USGS ash value, } 11 \text { major and minor } \\
\text { ash oxides, and up to } 62 \text { trace elements. }\end{array}$ \\
\hline
\end{tabular}

${ }^{1}$ American Society for Testing and Materials

${ }^{2}$ Carbon, Hydrogen, Nitrogen, Oxygen, and Sulfur

Details of the sampling and assay methods used for the COALQUAL data set are fully described in text accompanying the data on the CD-ROM format; several of these details are worth noting:

- The ASTM assays are reported on a whole-coal (moist) basis and the USGS assays are reported on a residual moisture basis where the residual moisture content of the analysis specimen was not measured. Quick and others (2003) showed a method to estimate residual moisture.

- Hydrogen values include the hydrogen in moisture. This convention has significance for the calculation of flue gas volumes, the calculation of heating values from elemental composition, and the calculation of the lower (net) heating value.

- Qualitative values (typically where an assay result was below the detection limit) are listed in the data set as the detection limit value multiplied by 0.7. Although the 
percentage of qualified values for each data field is reported, the status of individual records is not.

- Some data records are calculated, whole-bed composites where results from component partial-bed samples are mathematically combined by weighting component assays by volume (thickness) rather than mass; we ignored these records. Table 9 shows the tabulation of selected and ignored COALQUAL data records.

Table 9. Tabulation of selected and ignored COALQUAL data records

7,432 ORIGINAL RECORDS
948 Calculated composites ${ }^{1}$
568 No Btu, ash, or sulfur values ${ }^{1}$
551 Weathered coal $^{1}$
150 Outcrop samples $^{1}$
105 Anomalous moisture values $^{1}$
51 Geographically isolated, or Alaskan coal ${ }^{1}$
5,059 SELECTED RECORDS
1 ignored.

The 5059 selected COALQUAL data records (table 9) include samples collected from 340 U.S. counties. Comparison with coal production records (USEIA 2000; USMSHA, 2004) indicates that 3671 of the COALQUAL records originate from 146 of the approximately 170 counties that reported coal production during 1999.

\section{DOE-PSU Data}

Figure 5 shows the geographic distribution of the 73 selected DOE-PSU data records. The data are for coal samples collected between 1983 and 1995 from active mines in 48 U.S. counties and 18 U.S. states; they include 67 full-bed or working-section channel samples, 5 runof-mine samples, and 1 drill-hole core. Thirty-three (DOE) records are from Davis and Glick (1993) and Scaroni and others (1999). The remaining 40 (PSU) records are from Quick and Glick (2000) with additional information from the Pennsylvania State University Coal Data Base 
(anonymous, 1990). Petrographic assays, Gieseler fluidity, as well as major, minor, and trace element assays are from the Pennsylvania State University; the other assays are from a commercial laboratory. Data fields included in the DOE-PSU data are summarized in table 10.

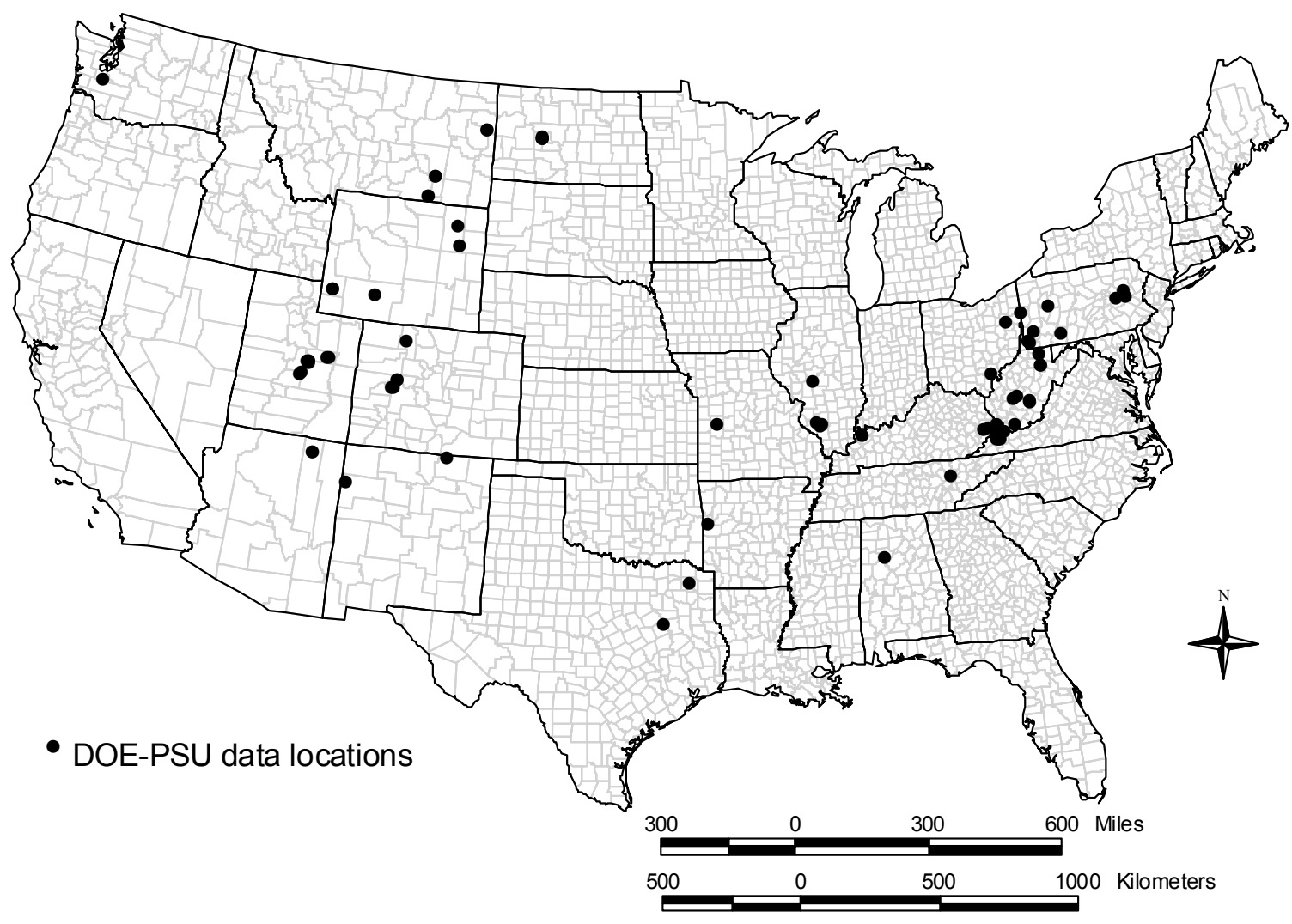

Figure 5. Geographic distribution of selected DOE-PSU data records.

Table 10. Summary of DOE-PSU data fields.

Location Information

Geologic Information

Collection Information

Sample Type

Assays
Including: state, county, coal province, region, field, quadrangle, latitude, and longitude.

Including: formation, group, bed, bed thickness, lithologic description, system, and geologic age.

Collection date, laboratory submission date, and assay dates.

Channel, working section, run-of-mine, drillcore.

As received and equilibrium moisture, Btu, ash, volatile matter, CHNOS, free swelling index, sulfur forms, chlorine, carbonate $\mathrm{CO}_{2}$, maceral components, vitrinite reflectance, Hardgrove grindability, Gieseler fluidity, ash fusion temperatures, major, minor, and trace elements. 


\section{CEA Data}

The Canadian Electricity Association (CEA) made coal, fly ash, and bottom ash composition data publicly available on its website (CEA, 2004). The data were collected to create an inventory of mercury emissions where emissions equal the difference between mercury in the fuel and mercury in the combustion ash. These preliminary data are weekly assays of composite samples for boiler fuel and by-product ash. The data include values for Btu, ash, sulfur, mercury, and chlorine in coal, as well as sulfur, moisture, mercury and carbon (LOI) in fly ash and bottom ash. The weekly unit data are posted on the CEA website as a series of quarterly reports in portable document format, for the nearly two-year testing program.

\section{Calculation Net Heating Values}

The CAMR includes output-based emission limits (pounds $\mathrm{Hg} \times 10^{-6}$ per megawatt-hour electricity manufactured) for power plants built after January 30, 2004 (table 11). The outputbased limits presumably assume 35 percent efficiency (9,833 gross Btu/kilowatt-hour) for new power plants (Cole, 2003). Although the USEPA used the gross heating value of coal to calculate the output-based emission, figure 6 shows that output-based emissions are better calculated from fuel emission factors expressed on a net energy basis.

The gross coal heating value, (also called the higher heating value) is the familiar Btu/lb (or $\mathrm{MJ} / \mathrm{kg}$ ) value reported from the laboratory. The gross heating value is measured by using a high-pressure, constant-volume combustion bomb. Because water vapor from combustion condenses inside the combustion bomb the gross heating value includes the latent heat of water vapor. Unlike the laboratory combustion bomb, combustion in a coal-fired boiler occurs at constant pressure and moisture from combustion exits the boiler with the flue gas. 
Consequently, the net heating value (also called the lower heating value) does not include the latent heat of water vapor and is a better measure of the energy available to the boiler than the gross heating value. Accordingly, we use emission factors expressed on a net energy basis to calculate output-based emissions. This required that we calculate county-average, ICR net heating values.

Table 11. CAMR standards of performance for new coal-fired power plants (gross electric output basis)

\begin{tabular}{lcc} 
Fuel/Technology Class & \multicolumn{1}{c}{ SI units } & U.S. customary units \\
Bituminous-fired Units: & $2.6 \mathrm{pg} \mathrm{Hg} / \mathrm{J}$ & $21 \times 10^{-6} \mathrm{lbs} \mathrm{Hg} / \mathrm{MWh}$ \\
$\begin{array}{c}\text { Subbituminous-fired Units } \\
\text { wet FGD: } \\
\text { dry FGD: }\end{array}$ & $5.3 \mathrm{pg} \mathrm{Hg} / \mathrm{J}$ & $42 \times 10^{-6} \mathrm{lbs} \mathrm{Hg/MWh}$ \\
$\quad 9.8 \mathrm{pg} \mathrm{Hg} / \mathrm{J}$ & $78 \times 10^{-6} \mathrm{lbs} \mathrm{Hg/MWh}$ \\
Lignite-fired Units: & $18.3 \mathrm{pg} \mathrm{Hg} / \mathrm{J}$ & $145 \times 10^{-6} \mathrm{lbs} \mathrm{Hg} / \mathrm{MWh}$ \\
Coal Refuse-fired Units: & $0.18 \mathrm{pg} \mathrm{Hg} / \mathrm{J}$ & $1.4 \times 10^{-6} \mathrm{lbs} \mathrm{Hg} / \mathrm{MWh}$ \\
Integrated Gasification & $2.5 \mathrm{pg} \mathrm{Hg} / \mathrm{J}$ & $20 \times 10^{-6} \mathrm{lbs} \mathrm{Hg/MWh}$ \\
Combined Cycle Units: & & \\
\hline
\end{tabular}
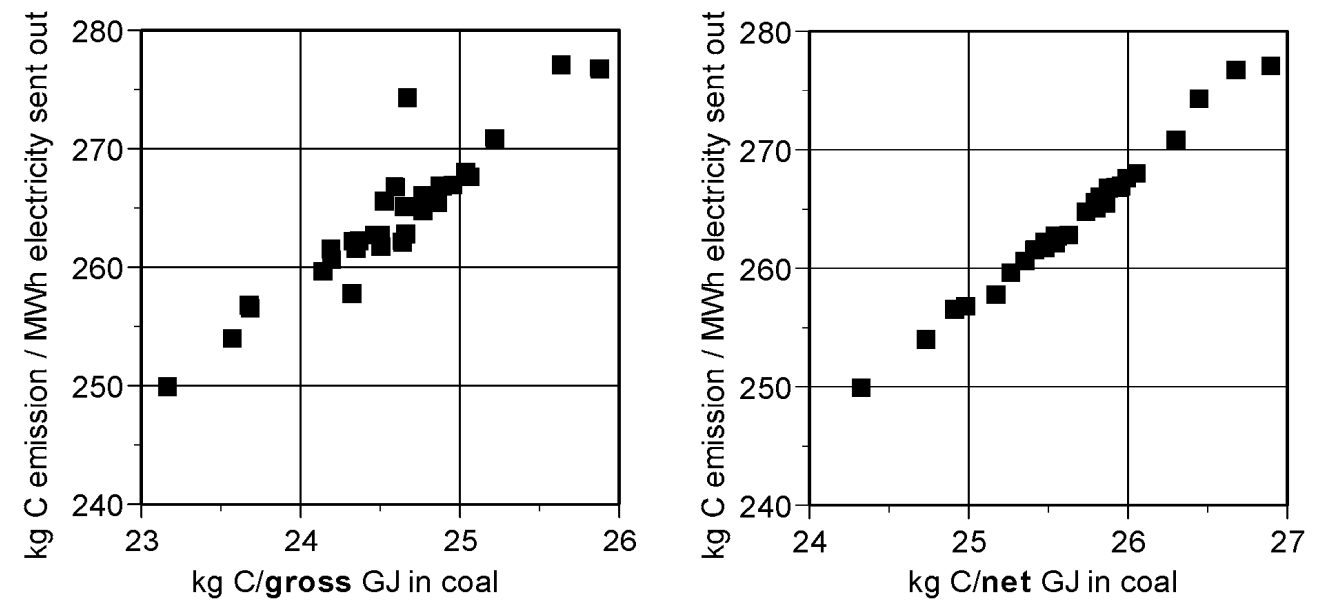

Figure 6. Emissions expressed on an output basis (vertical axes) are better estimated if the fuel emission factor is expressed on a net energy basis (right plot) rather than on a gross energy basis (left plot). Data show output-based carbon emissions calculated by Juniper (1998) for commercial coals in a model 500 MW plant equipped with ESP and FGD emissions controls. 
The net heating value is calculated as:

$$
B t u_{\text {net }}=B t u_{\text {gross }}-92.7(0.1119 M+H)
$$

where: Btu gross is the familiar Btu per pound value reported from the laboratory and expressed on a moist, whole-coal basis,

$M$ is the weight percent moisture content of the coal, $H$ is the weight percent hydrogen of the coal (not including hydrogen in coal moisture) expressed on a moist, whole-coal basis,

0.1119 is the gravimetric factor applied to the moisture value $(M)$ to obtain the weight percent hydrogen in coal moisture and,

92.7 is the Btu penalty, which is largely due to the latent heat of water vapor (Bowling, 1996), which is lost from the boiler with the combustion flue gas.

Note that the ICR data do not include moisture or hydrogen values, which are required for equation 1. Methods used to estimate and verify county-average ICR moisture and hydrogen values are described below.

\section{Estimating Moisture}

As noted above, the ICR data are reported on a dry basis, whereas the FERC 423 data are reported on a moist basis. Where data records are aggregated by county-of-origin, comparison of the two data sets allows moisture to be estimated (figure 7). Note that this approach is not accurate for individual coals but, as will be shown, does provide a reasonable average moisture value for the 169 U.S. counties in the ICR data. 
1. Calculate best-fit line for the FERC 423 data for a selected county-of-origin.

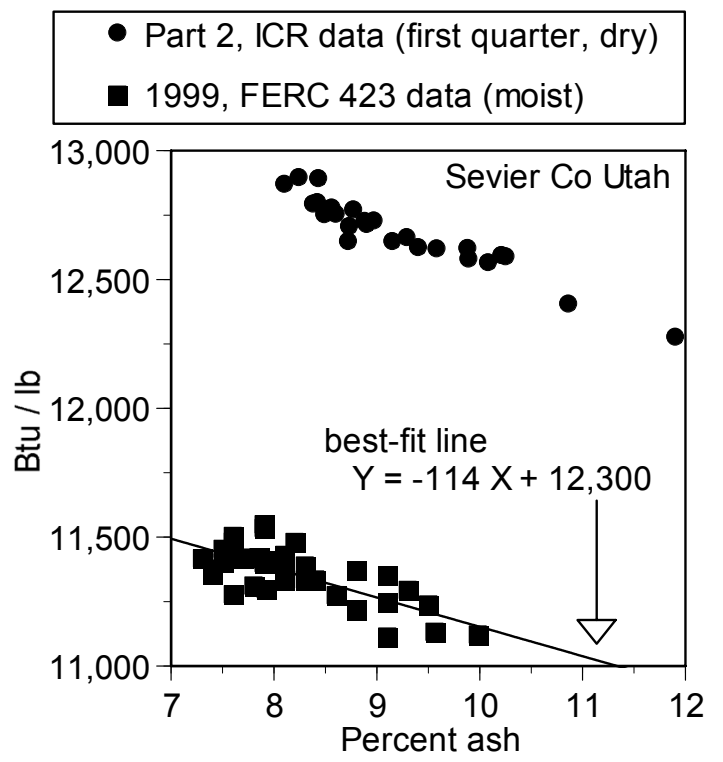

2. Algebraically estimate moisture values so ICR data move to the FERC 423 line.

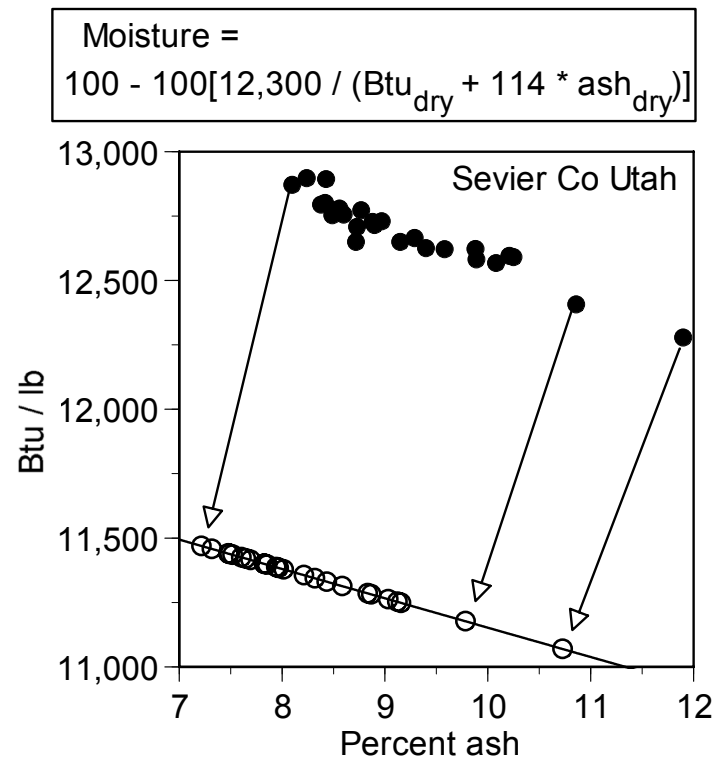

Figure 7. Illustration of the method used to estimate ICR moisture values. Note that the method is not valid for individual coals, but is useful to calculate an average moisture value for coals grouped by U.S. county-of-origin. Since the FERC 423 data are commonly too few or too homogeneous to calculate a best-fit line, a method is presented in the text to calculate an intercept value (12,300 above) to use in the regression analysis.

As illustrated in figure 7, the first step to estimate ICR moisture is to find the best-fit regression line for moist-basis FERC 423 data from a single U.S. county. The slope and intercept of this line are then used to calculate moisture values for the dry basis ICR data from the same county, and the average ICR moisture value is calculated.

The method works reasonably well for U.S. counties with abundant data. However, a significant best-fit regression line is not possible where the FERC 423 data are too few in number, or are too homogeneous. To solve this problem, the intercept value determined fixed according to regionally established relationships between the American Society for Testing and Materials (ASTM, 1990) rank parameter $\left(\mathrm{Btu} / \mathrm{lb}_{\mathrm{m}, \mathrm{mmf}}\right)$; the intercept value can then be used with the otherwise limited FERC 423 data to obtain a best-fit line. These regional relationships used 
to determine the intercept are made using plots of ash versus Btu/lb values for regional subsets of the FERC 423 data that are grouped according to $250 \mathrm{Btu} / \mathrm{lb}_{\mathrm{m}, \mathrm{mmf}}$ intervals. A regression intercept value is established for each group, and a second linear regression analysis between the group average $\mathrm{Btu} / \mathrm{lb}_{\mathrm{m}, \mathrm{mmf}}$ values and their corresponding intercepts provides a unique solution for each region. The regional solutions are listed in table 12.

Table 12. Equations used to estimate regional ash versus Btu intercept values for FERC 423 data.

\begin{tabular}{|c|c|c|}
\hline $\begin{array}{l}\text { BOM } \\
\text { district }\end{array}$ & Descriptive Geographic Extent & Equation \\
\hline 13 & $\begin{array}{l}\text { Eastern Province, southern Appalachian region: } \\
\text { Alabama and southern Tennessee. }\end{array}$ & Intercept $=1.315 \mathrm{Btu} / \mathrm{lb} \mathrm{m}, \mathrm{mmf}-4,541$ \\
\hline 7,8 & $\begin{array}{l}\text { Eastern Province, central Appalachian region: } \\
\text { northern Tennessee, eastern Kentucky, Virginia, } \\
\text { and southern West Virginia. }\end{array}$ & Intercept $=1.034 \mathrm{Btu} / \mathrm{lb}_{\mathrm{m}, \mathrm{mmf}}-519$ \\
\hline $1,2,3,4,6$ & $\begin{array}{l}\text { Eastern Province, northern Appalachian region: } \\
\text { Ohio, northern West Virginia, and Pennsylvania. }\end{array}$ & Intercept $=0.9811 \mathrm{Btu} / \mathrm{lb}_{\mathrm{m}, \mathrm{mmf}}+225$ \\
\hline $9,10,11$ & $\begin{array}{l}\text { Eastern Interior Province (Illinois Basin): western } \\
\text { Kentucky, Indiana, and Illinois. }\end{array}$ & Intercept $=0.9699 \mathrm{Btu} / \mathrm{lb}_{\mathrm{m}, \mathrm{mmf}}+361$ \\
\hline 15 & $\begin{array}{l}\text { Western Interior Province: Kansas, Missouri, and } \\
\text { Oklahoma. }\end{array}$ & Intercept $=1.127 \mathrm{Btu} / \mathrm{lb} \mathrm{m}_{\mathrm{mmf}}-1,859$ \\
\hline 15 & Gulf Province: Texas and Louisiana. & Intercept $=0.7883 \mathrm{Btu} / \mathrm{lb}_{\mathrm{m}, \mathrm{mmf}}+1,652$ \\
\hline 17 & Rocky Mountain Province: Colorado. & Intercept $=1.002 \mathrm{Btu} / \mathrm{lb} \mathrm{m}_{\mathrm{mmf}}+111$ \\
\hline $18,19,20$ & $\begin{array}{l}\text { Rocky Mountain Province: southern Wyoming, } \\
\text { Utah, New Mexico, and Arizona. }\end{array}$ & Intercept $=0.9936 \mathrm{Btu} / \mathrm{lb}_{\mathrm{m}, \mathrm{mmf}}+73$ \\
\hline $19,21,22$ & $\begin{array}{l}\text { Northern Great Plains Province: northeastern } \\
\text { Wyoming, Montana, and North Dakota. }\end{array}$ & Intercept $=1.088 \mathrm{Btu} / \mathrm{lb}_{\mathrm{m}, \mathrm{mmf}}-804$ \\
\hline $1,7,8,24$ & $\begin{array}{l}\text { Eastern Province counties with medium volatile } \\
\text { bituminous and higher rank coal: Allegany and } \\
\text { Garrett Counties Maryland; Bedford, Cambria, } \\
\text { Clearfield, Lackawanna, Lycoming, Schuylkill, } \\
\text { Somerset, and Sullivan Counties Pennsylvania; } \\
\text { Tazewell Co Virginia; Grant, Greenbrier, } \\
\text { McDowell, Mercer, Raleigh, and Wyoming } \\
\text { Counties West Virginia. }\end{array}$ & Intercept $=0.9827 \mathrm{Btu} / \mathrm{lb}_{\mathrm{m}, \mathrm{mmf}}+217$ \\
\hline
\end{tabular}

Note that the $B t u / / b_{m, m m f}$ value used in the listed equation is calculated from the county-average, FERC 423 data using the equation: Btu / I $b_{m, m m f}=\frac{100\left(\text { Btu }_{\text {FERC } 423}-50 \text { Sulfur }_{\text {FERC423 }}\right)}{\left[100-\left(1.08 \text { Ash }_{\text {FERC223 }}+0.55 \text { Sulfur }_{F E R C 423}\right)\right]}$.

The average Btu/lb m,mm value calculated using FERC 423 data from a single U.S. county is used with the appropriate equation listed in table 12 to obtain the intercept value. This 
intercept value is then fixed during the ash versus Btu/lb regression analysis (figure 7, part 1) to obtain the best-fit line. The line slope and intercept are then used to estimate the ICR coal moisture values (figure 7, part 2), and the average moisture content is calculated for the U.S. county.

\section{Verification of Estimated Moisture Values}

Figure 8 shows a cross plot of coal moisture values observed in the CTRDB data with the corresponding coal moisture values calculated for the ICR data; each data point represents a county average. The figure shows a nearly 1:1 relationship, and a standard error of about one percent moisture. The most notable outlier is for Moffat County, Colorado where the CTDRB includes a lower moisture population not observed in the ICR, or FERC 423 data. The CTRDB data records for the low moisture population list Eagle/Fiodel as the mine name. Since the Fiodel mine is located in Routt, rather than Moffat, County unrecognized location errors are likely responsible for this and perhaps other deviations in figure 8.

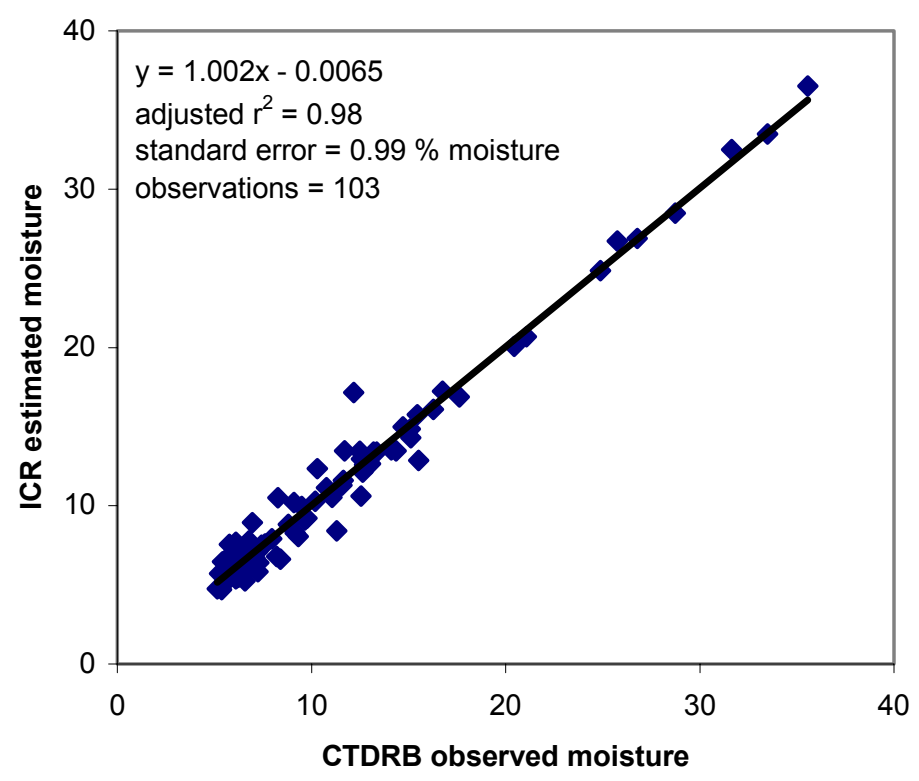

Figure 8. The estimated ICR moisture values are nearly the same as the observed CTRDB moisture values; each data point is a U.S. county average. 
Further verification of the estimated ICR moisture values is illustrated in figure 9. Figure 9a shows that the relationship between the Btu/lb $\mathrm{mmmf}$ rank parameter (ASTM, 1990) and coal moisture is essentially identical for both the ICR and CTRDB data. Perhaps more significant is the similar provincial variation of coal moisture values for these two data sets shown in figures $9 \mathrm{~b}$ and $9 \mathrm{c}$. For example, both the ICR and CTRDB data show that U.S. Interior province coal has more moisture than Rocky Mountain province coal of the same rank (Btu/lb $\left.\mathrm{b}_{\mathrm{m}, \mathrm{mmf}}\right)$. Calculations (not shown) show that this provincial variation of moisture content is not caused by differences in mineral content.

A significant geographic component of coal moisture content may also be present within provincial groups of coal. McCutcheon and Barton (1999) showed that the mineral components of coal contain less moisture than the organic components. Accordingly, we used multivariate regression analysis, where the $\mathrm{Btu} / \mathrm{lb} \mathrm{m}_{\mathrm{m}, \mathrm{mm}}$ and the Parr mineral matter values are used together to predict moisture. Although mineral matter does show the expected negative correlation with moisture for Gulf and Eastern province coals, it is not a significant factor to explain moisture variation for Interior, Rocky Mountain, or Northern Great Plains province coal. Given the importance of coal moisture for calculation of coal rank (ASTM, 1990), taxes and fees (Neavel, 1990; Luppens and Hoeft, 1991), and boiler efficiency (Sarunac and others, 2005) the impact of mineral content on coal moisture deserves further study. 

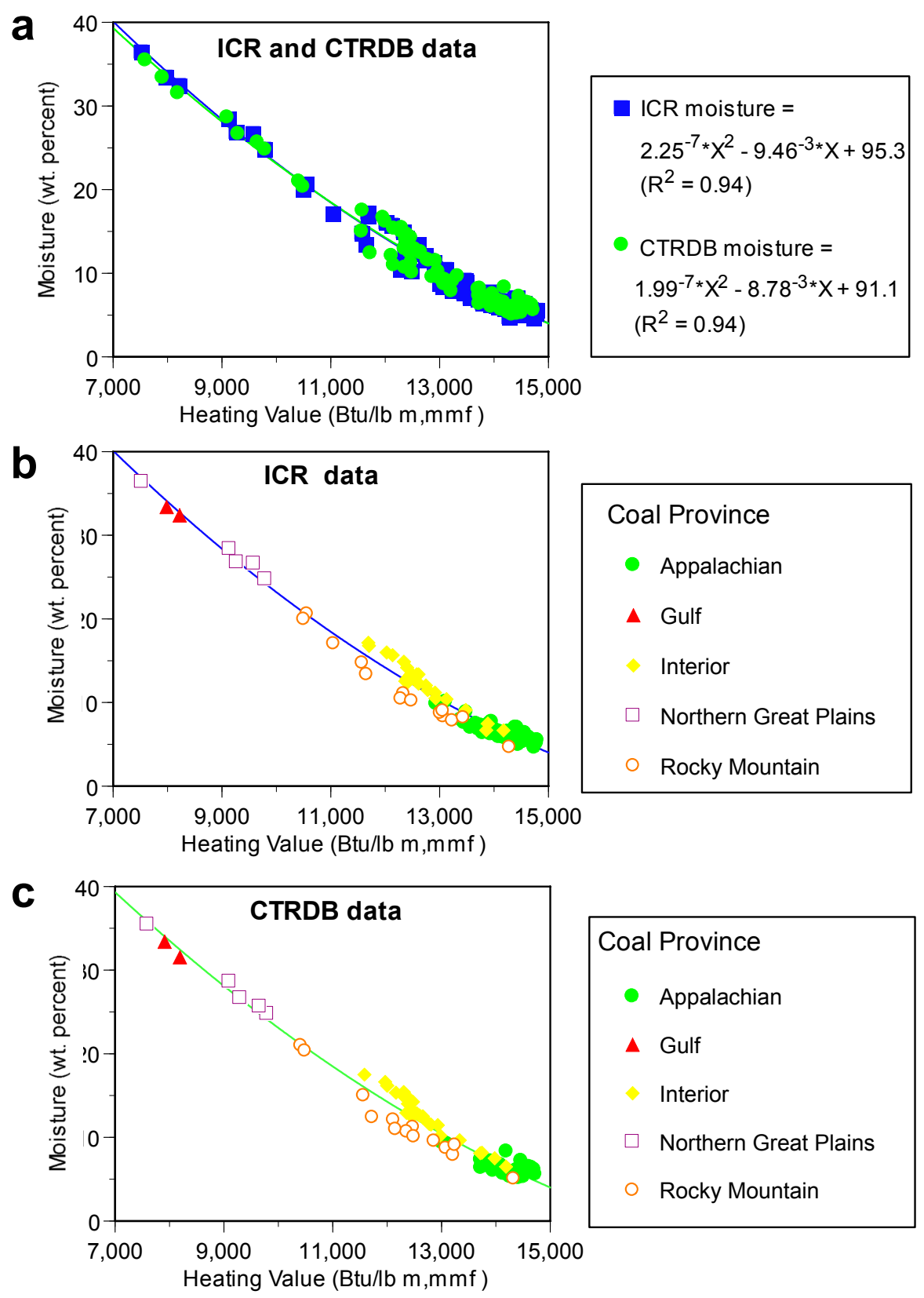

Figure 9. The essentially identical relationships between the coal heating value and coal moisture content for the ICR and CTRDB data (a) verify the estimated moisture values for the ICR data. The similar provincial distribution of moisture values around each line $(\mathbf{b}, \mathbf{c})$ is likewise significant. Each data point is a U.S. county population average. The standard error for both lines is $1.2 \%$ moisture. 


\section{Estimating Hydrogen}

A multivariate regression method was applied to selected COALQUAL data (MottSpooner [1940] values within $\pm 250 \mathrm{Btu}$, appendix A) to develop a set of geographically specific equations to predict coal hydrogen from dry-basis Btu/lb, ash, and sulfur values. The equations were validated using the PSU-DOE data, and used to estimate ICR coal hydrogen values.

The dependent COALQUAL variable was dry-basis hydrogen. Note that moist-basis hydrogen values, which include hydrogen in coal moisture, are listed in the COALQUAL data set. Consequently, the COALQUAL hydrogen values were adjusted to a dry basis by subtracting the stochiometric contribution of hydrogen to water $(0.1119 \times$ moisture $)$, and multiplying the result by $\frac{100}{100-\text { moisture }}(\mathrm{ASTM}, 2000 \mathrm{a})$.

The four independent variables used in the regression analysis $\left(\mathrm{Btu}_{\mathrm{dmmf}}, \mathrm{Btu}_{\mathrm{dmmf}} \stackrel{2}{2}, \mathrm{MM}_{\mathrm{Parr}, \mathrm{dry}}\right.$, and Ibs S/million Btu) were calculated for the selected COALQUAL data records using the equations:

$$
\begin{aligned}
& B t u_{d m m f}=\frac{100 \times\left(B t u_{d r y}-50 S_{d r y}\right)}{100-\left(1.08 A s h_{d r y}+0.55 S_{d r y}\right)} \\
& B t u_{d m m f}{ }^{2}=B t u_{d m m f} \times B t u_{d m m f} \\
& M M_{\text {Parr }, d r y}=1.08 A s h_{d r y}+0.55 S_{d r y} \\
& \text { Ibs S/million Btu }=\frac{10^{6}}{B t u_{d r y}} \times \frac{S_{d r y}}{100}
\end{aligned}
$$

where, $\quad B t u_{d r y}$ is the dry-basis Btu per pound value,

$\mathrm{S}_{\text {dry }}$ is the dry-basis weight percent sulfur, and

Ash $_{\text {dry }}$ is the dry-basis weight percent ash.

Although the regression equations were obtained using relationships observed in the COALQUAL data, they were used to predict ICR coal hydrogen values. Consequently, the 
selection of the independent variables was necessarily constrained by the available ICR assay data (Btu/lb, ash, $\mathrm{S}, \mathrm{Cl}, \mathrm{Hg}$, and estimated moisture). Considering this constraint, the independent variables were selected to indicate coal rank, $\left(B t u_{d m m f}\right.$ and $\left.B t u_{d m m f}{ }^{2}\right)$, coal grade $\left(\mathrm{MM}_{\text {Parr,dry }}\right)$, and coal type (Ibs S/million Btu), all of which may influence the hydrogen content of coal. For example, the influence of coal rank is illustrated in figure 10, which shows that coal hydrogen increases slightly through the coalification series to a maximum in the high volatile A bituminous stage, and then decreases as rank advances to the anthracite stage.

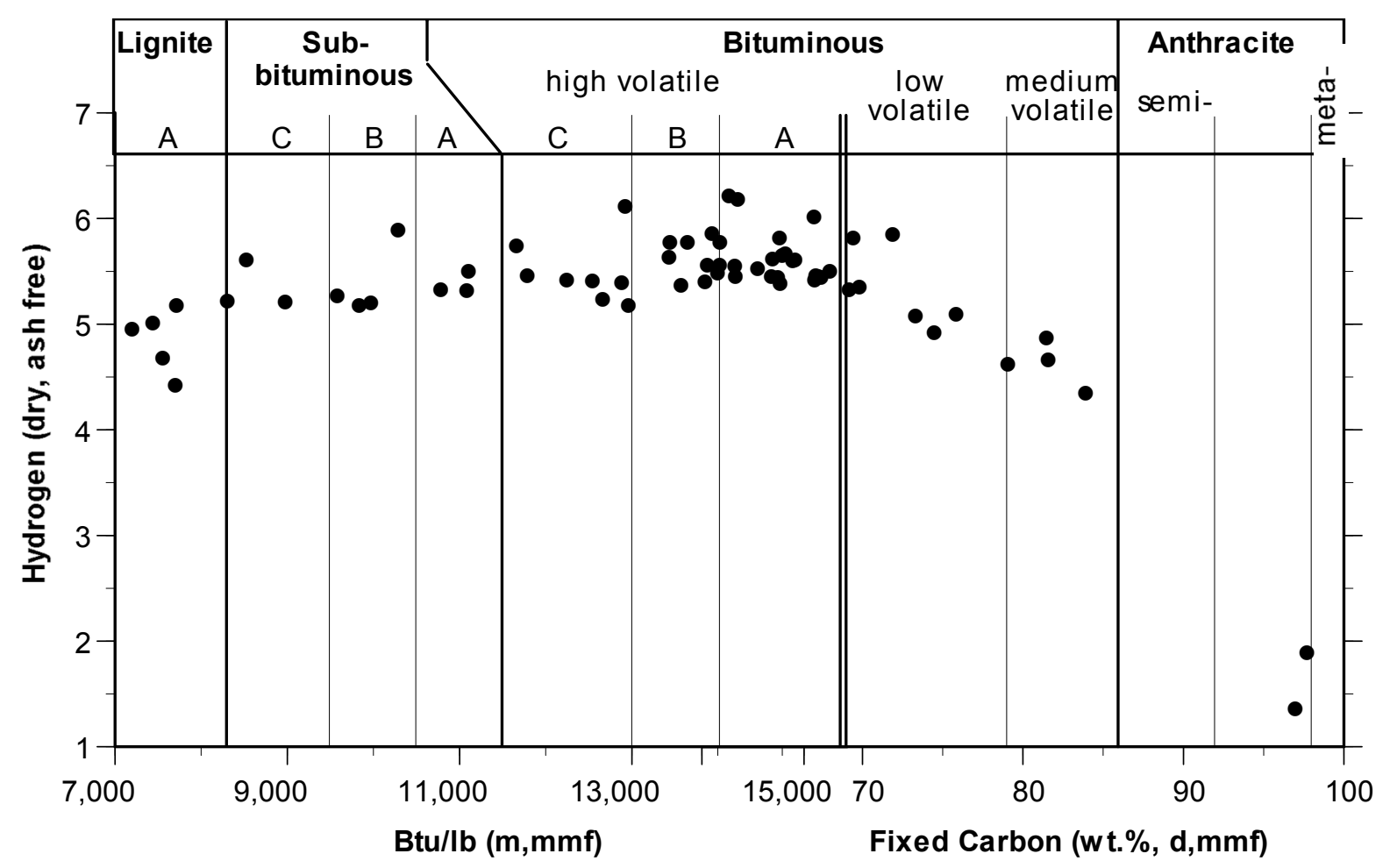

Figure 10. Variation of coal hydrogen with ASTM (1990) coal rank (PSU-DOE data).

Note that the ASTM rank classification (figure 10) requires two parameters: (1) the Btu value on a moist, mineral-matter-free basis [Btu/lb $(\mathrm{m}, \mathrm{mmf})]$ and $(2)$ the fixed carbon value on a dry, mineral-matter-free basis [Fixed Carbon (d,mmf)]. Regrettably, neither parameter could be used as an independent variable in the regression analysis to predict coal hydrogen. We used the $\mathrm{Btu} / \mathrm{lb}$ value on a dry, mineral-matter-free basis (instead of the moist, mineral-matter-free basis 
used in the ASTM rank classification) because the COALQUAL moisture values are systematically lower than those observed in other data sets (figure 11). The fixed carbon parameter could not be used because fixed carbon values are not included in the ICR data.

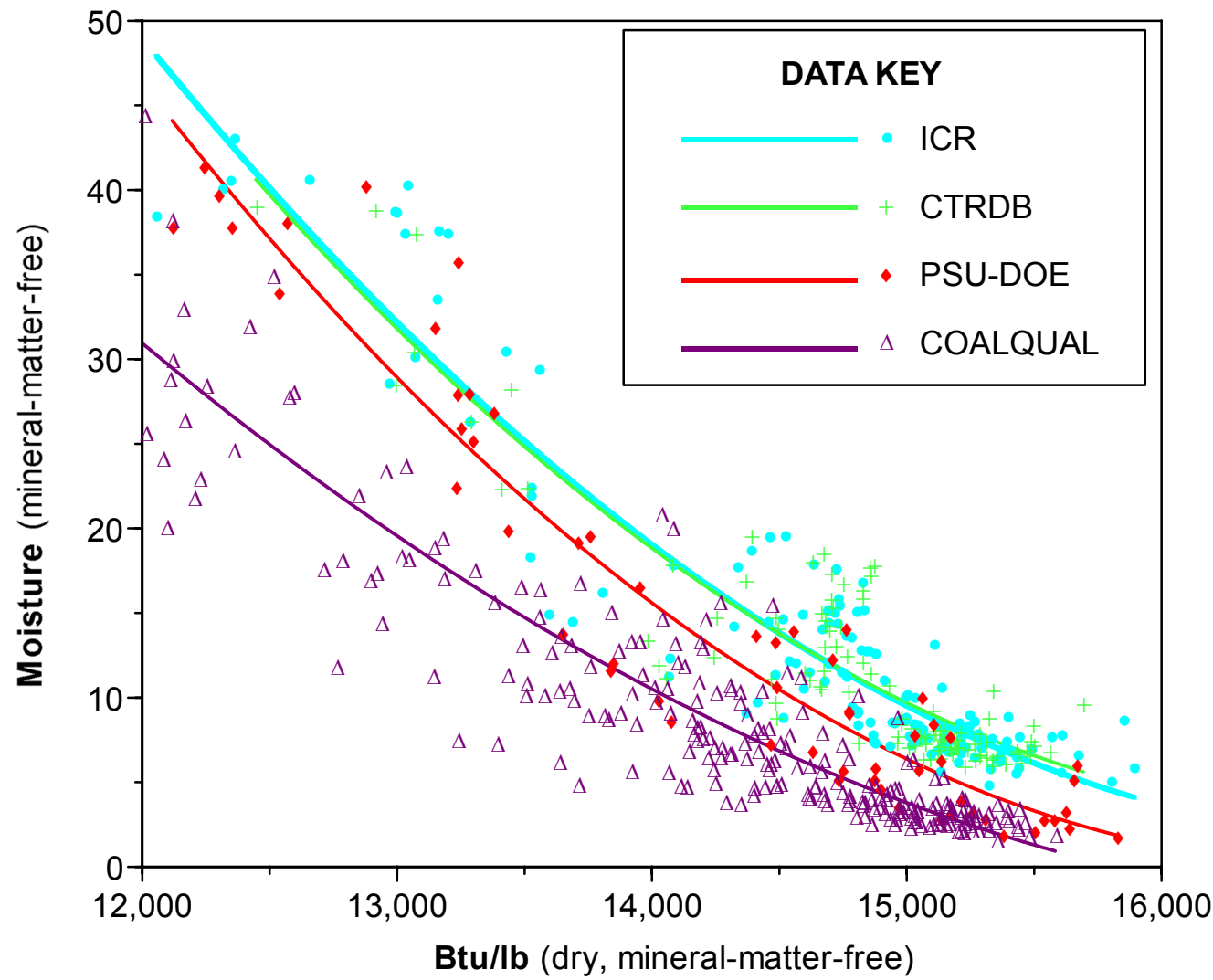

Figure 11. COALQUAL moisture values are lower than moisture values for other data sets. Notes: The ICR moisture values are estimated, county-average, as-shipped values. The CTRDB, and COALQUAL data points show measured, county-average moisture values (as-received basis). The PSUDOE data points show equilibrium moisture values for single coal assays. Data from U.S. counties with medium volatile bituminous or higher rank coal are not shown. Also not shown are data for 46 counties included in the COALQUAL data where the average dry, mineral-matter-free Btu value is less than 12,000 (the ICR, CTRDB, and PSU-DOE data do not include data records where the dry, mineral-matter-free $\mathrm{Btu} / \mathrm{lb}$ value is less than 12,000 ). The Btu/lb (dry, mineral-matter-free) values were calculated using equation 2 (see text). Moisture (mineral-matter-free) $\left(M_{m m f}\right)$ was calculated as: $M_{m m f}=$ Moisture [100/(1.08 Ash moist +0.55 Sulfur $\left.\left._{\text {moist }}\right)\right]$. The best-fit lines correspond to: ICR $\mathrm{M}_{\mathrm{mmf}}=1.82 \mathrm{E}^{-6}\left(\mathrm{Btu} / \mathrm{lb}_{\mathrm{d}, \mathrm{mmf}}{ }^{2}\right)$ 6.22 $\mathrm{E}^{-2} \mathrm{Btu} / \mathrm{lb}_{\mathrm{d}, \mathrm{mmf}}+533,\left(\mathrm{R}^{2}=0.88\right) ; \mathrm{CTRDB} \mathrm{M}_{\mathrm{mmf}}=1.92 \mathrm{E}^{-6}\left(\mathrm{Btu}_{/ \mathrm{lb}} \mathrm{b}_{\mathrm{dmm}}{ }^{2}-6.47 \mathrm{E}^{-2}\right) \mathrm{Btu} / \mathrm{lb}_{\mathrm{d}, \mathrm{mmf}}+549,\left(\mathrm{R}^{2}\right.$ $=0.83) ;$ PSU-DOE $M_{m m f}=2.05 \mathrm{E}^{-6}\left(B t u / \mathrm{lb}_{\mathrm{d}, \mathrm{mmf}}{ }^{2}\right)-6.88 \mathrm{E}^{-2} \mathrm{Btu} / \mathrm{lb}_{\mathrm{d}, \mathrm{mmf}}+576,\left(\mathrm{R}^{2}=0.92\right)$; and COALQUAL $M_{m m f}=1.17 E^{-6}\left(B t u / / b_{d, m m f}{ }^{2}\right)-4.05 E^{-2} B t u / l b_{d, m m f}+349,\left(R^{2}=0.94\right)$. 
The relationship between coal rank and coal hydrogen (figure 10) also shows that hydrogen declines at higher ranks with increasing fixed carbon. This indicates that different equations are required for high and low-rank coals. Accordingly, fixed carbon values listed in the COALQUAL data were used to identify U.S. counties with high-rank coal. COALQUAL data values (Btu $\mathrm{dmmf}_{\mathrm{m}}, \mathrm{Btu}_{\mathrm{dmmf}}{ }^{2}, \mathrm{MM}_{\text {Parr, dry }}$, and Ibs S/million Btu values) from these counties were used to establish equations to predict the hydrogen content of high-rank coal, and the equations were applied to the ICR data originating from the same counties.

Attempts to develop a single equation to predict hydrogen for high volatile A bituminous (hvAb) and lower rank coals gave unsatisfactory results. The results overestimated coal hydrogen in some geographic regions and underestimated coal hydrogen in others. For example, a multiple regression equation based on all the COALQUAL data for hvAb and lower rank coal (not shown), gave average residuals of $-0.15 \%$ hydrogen for Western Interior coal and $+0.23 \%$ hydrogen for Gulf Coast coal. To avoid these systematic errors, equations to predict coal hydrogen were determined for coal from each of the geographic regions shown in figure 12.

The regression equations used to predict coal hydrogen in this report are described in table 13. Several results are noteworthy. Excluding high-rank coal, relatively large t-statistic values, and consistently negative coefficients for the coal grade parameter ( $\left.\mathrm{MM}_{\mathrm{Parr}, \mathrm{dry}}\right)$ show the strong influence of mineral matter content on coal hydrogen; coal hydrogen declines with increasing mineral content. The general lack of significance (t-statistic $<2)$ for the rank parameter $\left(B t u_{d m m}\right)$ for coal from the Western Interior and Northern Great Plains groups may be due to small range of variation of the Btu variable in coal from these areas. Although the type parameter (Ibs S/million Btu) is typically the least significant of the independent variables, its 


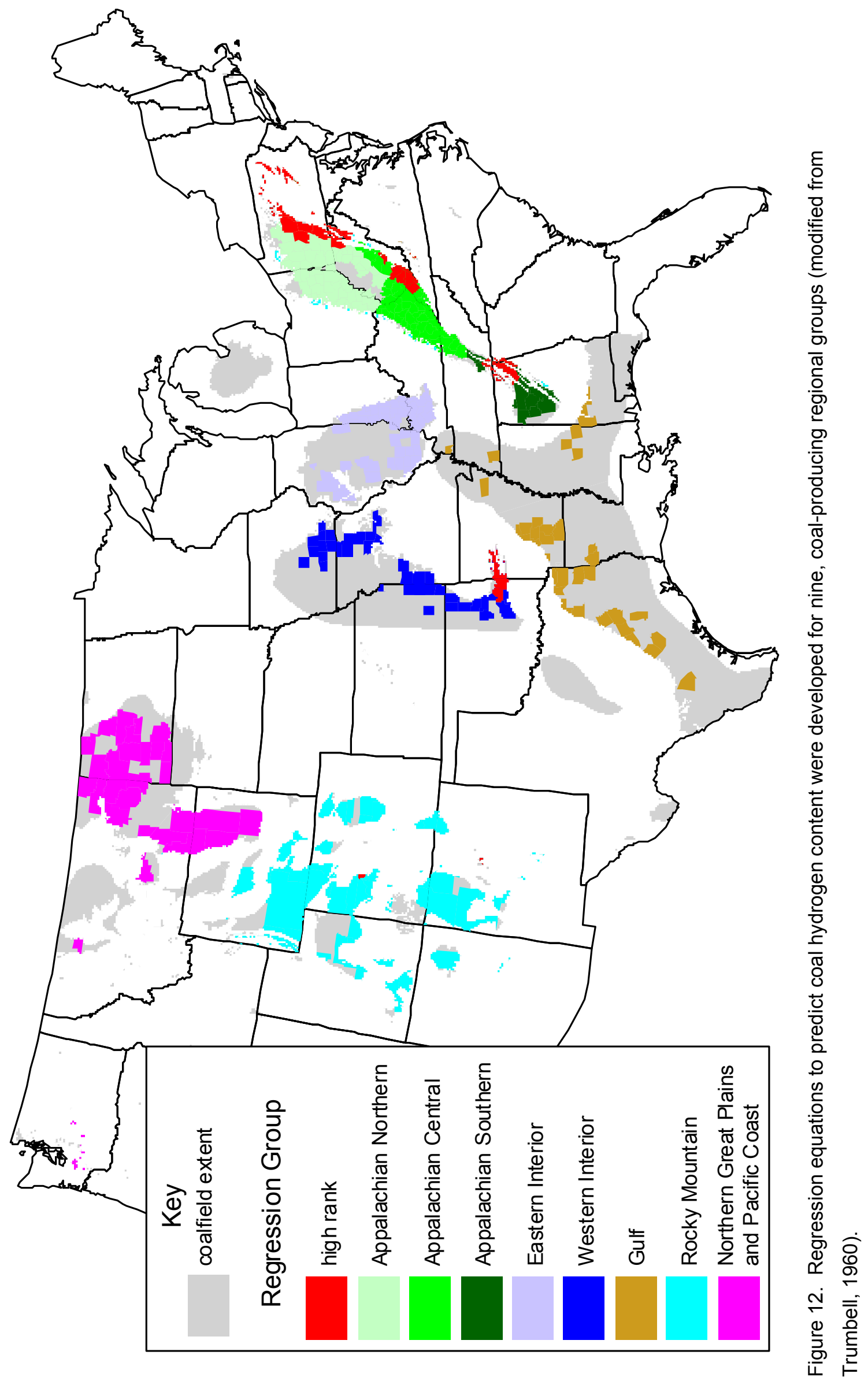


generally positive coefficient is consistent with the geologic enrichment of coal hydrogen due to the preservation of otherwise labile hydrogen-rich compounds by an early diagenetic natural vulcanization process where aliphatic compounds are cross-linked by hydrogen sulfide from sulfate-reducing bacteria (Sinninghe Damste and others, 1989). The inability of the sulfur variable to predict coal hydrogen for coal from five of the nine groups $(\mathrm{t}$-statistic $<2)$ is also noteworthy and may have varied origins; possibilities include (1) a late-stage abiogenic sulfide

contribution to Western Interior coal (after diagenetic loss of labile hydrogen), (2) greater initial hydrogen of geologically younger (western U.S.) peat-forming biomass (more H-rich cellulose; Robinson, 1990) with early bacterial stripping of hydrogen by methanogenic bacteria, which thrive in the absence of dissolved sulfate (Belyaev and others, 1980), and (3) catagenetic loss of hydrogen associated with sulfur in aliphatic structures, as aliphatic sulfur is lost or transformed into aromatic sulfur at higher ranks (Maes and others, 1997; Gorbaty and Kelemen, 2001).

\section{Verification of Estimated Hydrogen Values}

The geographically specific equations used to predict coal hydrogen are described in table 13. These equations were applied to the PSU-DOE data to verify their accuracy. Figure 13 shows the near 1:1 correspondence between the measured PSU-DOE hydrogen values and the predicted PSU-DOE hydrogen values. Error bars on the figure correspond to an assay reproducibility of $0.3 \%$ hydrogen (ASTM, 2000b) and show that most of the scatter can be attributed to the limited precision of the hydrogen assay. The departure of two, low-hydrogen coals (anthracite rank) from the forced regression line suggests that the regression model is not well suited to predict the hydrogen content of anthracite. 
Table 13. List of variables, coefficients, and statistics for geographically specific regression equations used to predict the hydrogen content of coal (see text for variable descriptions).

\begin{tabular}{|c|c|c|c|c|c|}
\hline Data Group & variable name & coeffi & cient & t-statistic & equation statistics \\
\hline $\begin{array}{l}\text { Northern } \\
\text { Appalachian }\end{array}$ & $\begin{array}{r}\text { Intercept } \\
\text { Btu }_{\mathrm{dmmf}} \\
\mathrm{Btu}_{\mathrm{dmmf}} \\
\mathrm{MM}_{\text {Parr,dry }} \\
\text { Ibs S/million Btu }\end{array}$ & $\begin{array}{l}-56.22 \\
-2.82 \\
8.35 \\
-5.34 \\
5.97\end{array}$ & $\begin{array}{l}\mathrm{E}-07 \\
\mathrm{E}-03 \\
\mathrm{E}-02 \\
\mathrm{E}-02\end{array}$ & $\begin{array}{l}14.9 \\
16.4 \\
16.4 \\
49.1 \\
12.0\end{array}$ & $\begin{aligned} \text { adjusted } R^{2} & =0.75 \\
\text { standard error } & =0.18 \\
\text { observations } & =1028\end{aligned}$ \\
\hline $\begin{array}{l}\text { Central } \\
\text { Appalachian }\end{array}$ & $\begin{array}{r}\text { Intercept } \\
\text { Btu }_{2 \mathrm{dmmf}} \\
\mathrm{Btu}_{\mathrm{dmmf}} \\
\mathrm{MM}_{\mathrm{Parr}, \mathrm{dry}} \\
\text { Ibs S/million Btu } \\
\end{array}$ & $\begin{array}{c}-55.81 \\
-2.76 \\
8.22 \\
-5.10 \\
1.06 \\
\end{array}$ & $\begin{array}{l}E-07 \\
\text { E-03 } \\
\text { E-02 } \\
\text { E-01 }\end{array}$ & $\begin{array}{l}18.1 \\
19.5 \\
19.7 \\
39.6 \\
12.7 \\
\end{array}$ & $\begin{array}{r}\text { adjusted } R^{2}=0.74 \\
\text { std. error }=0.19 \\
\text { observations }=756\end{array}$ \\
\hline $\begin{array}{l}\text { Southern } \\
\text { Appalachian }\end{array}$ & $\begin{array}{r}\text { Intercept } \\
\text { Btu }_{\mathrm{dmmf}} \\
\mathrm{Btu}_{\mathrm{dmmf}} \\
\mathrm{MM}_{\text {Parr,dry }} \\
\text { Ibs S/million Btu }\end{array}$ & $\begin{array}{l}-65.88 \\
-3.19 \\
9.55 \\
-5.145 \\
7.323\end{array}$ & $\begin{array}{l}\mathrm{E}-07 \\
\mathrm{E}-03 \\
\mathrm{E}-02 \\
\mathrm{E}-02\end{array}$ & $\begin{array}{r}13.3 \\
14.3 \\
14.4 \\
36.0 \\
9.4\end{array}$ & $\begin{array}{r}\text { adjusted } R^{2}=0.71 \\
\text { std. error }=0.21 \\
\text { observations }=647\end{array}$ \\
\hline $\begin{array}{l}\text { Eastern } \\
\text { Interior }\end{array}$ & $\begin{array}{r}\text { Intercept } \\
\text { Btu }_{\mathrm{dmmf}} \\
\mathrm{Btu}_{\mathrm{dmmf}} \\
\mathrm{MM}_{\mathrm{Parr}, \mathrm{dry}} \\
\text { Ibs S/million Btu }\end{array}$ & $\begin{array}{l}-41.39 \\
-2.11 \\
6.30 \\
-5.33 \\
2.55\end{array}$ & $\begin{array}{l}\mathrm{E}-07 \\
\mathrm{E}-03 \\
\mathrm{E}-02 \\
\mathrm{E}-02\end{array}$ & $\begin{array}{r}2.8 \\
3.0 \\
3.1 \\
17.9 \\
2.9\end{array}$ & $\begin{array}{r}\text { adjusted } R^{2}=0.73 \\
\text { std. error }=0.15 \\
\text { observations }=220\end{array}$ \\
\hline $\begin{array}{l}\text { Western } \\
\text { Interior }\end{array}$ & $\begin{array}{r}\text { Intercept } \\
\text { Btu }_{\mathrm{dmmf}} \\
\mathrm{Btu}_{\mathrm{dmmf}} \\
\mathrm{MM}_{\text {Parr,dry }} \\
\text { Ibs S/million Btu }\end{array}$ & $\begin{array}{r}-4.54 \\
-3.54 \\
1.21 \\
-5.00 \\
2.94\end{array}$ & $\begin{array}{l}E-08 \\
\text { E-03 } \\
\text { E-02 } \\
\text { E-03 }\end{array}$ & $\begin{array}{r}-0.6 \\
-0.9 \\
1.1 \\
14.2 \\
0.3\end{array}$ & $\begin{array}{r}\text { adjusted } R^{2}=0.82 \\
\text { std. error }=0.19 \\
\text { observations }=170\end{array}$ \\
\hline $\begin{array}{l}\text { Gulf } \\
\text { Coast }\end{array}$ & $\begin{array}{r}\text { Intercept } \\
\text { Btu }_{\mathrm{dmmf}} \\
\mathrm{Btu}_{\mathrm{dmmf}} \\
\mathrm{MM}_{\mathrm{Parr}, \mathrm{dry}} \\
\text { Ibs S/million Btu }\end{array}$ & $\begin{array}{r}20.97 \\
1.35 \\
-2.95 \\
-3.95 \\
-5.27\end{array}$ & $\begin{array}{l}E-07 \\
\text { E-03 } \\
\text { E-02 } \\
\text { E-02 }\end{array}$ & $\begin{array}{r}2.5 \\
2.4 \\
-2.2 \\
10.4 \\
-1.9\end{array}$ & $\begin{array}{r}\text { adjusted } R^{2}=0.73 \\
\text { std. error }=0.23 \\
\text { observations }=66\end{array}$ \\
\hline $\begin{array}{l}\text { Rocky } \\
\text { Mountain }\end{array}$ & $\begin{array}{r}\text { Intercept } \\
\text { Btu }_{\mathrm{dmmf}} \\
\mathrm{Btu}_{\mathrm{dmmf}} \\
\mathrm{MM}_{\text {Parr,dry }} \\
\text { Ibs S/million Btu }\end{array}$ & $\begin{array}{r}-5.87 \\
-3.39 \\
1.29 \\
-4.31 \\
2.41\end{array}$ & $\begin{array}{l}E-08 \\
E-03 \\
E-02 \\
E-02\end{array}$ & $\begin{array}{r}5.4 \\
5.7 \\
8.0 \\
40.5 \\
1.7\end{array}$ & $\begin{aligned} \text { adjusted } R^{2} & =0.83 \\
\text { std. error } & =0.20 \\
\text { observations } & =641\end{aligned}$ \\
\hline $\begin{array}{l}\text { Northern } \\
\text { Great Plains, } \\
\text { Pacific Coast }\end{array}$ & $\begin{array}{r}\text { Intercept } \\
\text { Btu }_{2 \mathrm{dmmf}} \\
\mathrm{Btu}_{\mathrm{dmmf}} \\
\mathrm{MM}_{\mathrm{Parr}, \mathrm{dry}} \\
\text { Ibs S/million Btu } \\
\end{array}$ & $\begin{array}{r}1.88 \\
5.98 \\
1.64 \\
-3.88 \\
3.80 \\
\end{array}$ & $\begin{array}{l}E-09 \\
\text { E-04 } \\
\text { E-02 } \\
\text { E-03 }\end{array}$ & $\begin{array}{r}0.5 \\
0.3 \\
0.3 \\
20.4 \\
0.3 \\
\end{array}$ & $\begin{array}{r}\text { adjusted } R^{2}=0.72 \\
\text { std. error }=0.19 \\
\text { observations }=502\end{array}$ \\
\hline $\begin{array}{l}\text { High Rank } \\
\qquad \text { (mvb to Ivb) }\end{array}$ & $\begin{array}{r}\text { Intercept } \\
\text { Btu }_{2 \mathrm{dmmf}} \\
\mathrm{Btu}_{\mathrm{dmmf}} \\
\mathrm{MM}_{\mathrm{Parr}, \mathrm{dry}} \\
\text { Ibs S/million Btu }\end{array}$ & $\begin{array}{c}-35.66 \\
-1.66 \\
5.20 \\
-4.19 \\
3.91 \\
\end{array}$ & $\begin{array}{l}\mathrm{E}-07 \\
\mathrm{E}-03 \\
\mathrm{E}-02 \\
\mathrm{E}-02\end{array}$ & $\begin{array}{l}5.9 \\
6.1 \\
6.0 \\
1.4 \\
1.6 \\
\end{array}$ & $\begin{array}{r}\text { adjusted } R^{2}=0.52 \\
\text { std. error }=0.28 \\
\text { observations }=362\end{array}$ \\
\hline (anthracite) & $\begin{array}{r}\text { Intercept } \\
\text { Btu }_{\mathrm{dmmf}} \\
\mathrm{Btu}_{\mathrm{dmmf}} \\
\mathrm{MM}_{\mathrm{Parr}, \mathrm{dry}} \\
\text { Ibs S/million Btu }\end{array}$ & $\begin{array}{l}209.20 \\
1.02 \\
-2.92 \\
1.74 \\
-4.78\end{array}$ & $\begin{array}{l}E-06 \\
E-02 \\
E-02 \\
E-01\end{array}$ & $\begin{array}{l}5.9 \\
6.1 \\
6.0 \\
1.4 \\
1.6\end{array}$ & $\begin{aligned} \text { adjusted } R^{2} & =0.67 \\
\text { std. error } & =0.38 \\
\text { observations } & =25\end{aligned}$ \\
\hline
\end{tabular}




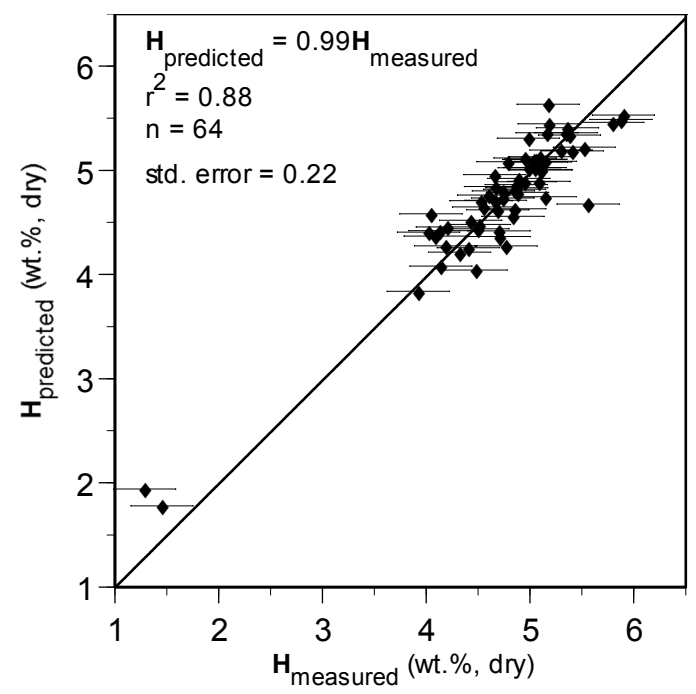

Figure 13. A near 1:1 relationship is observed between the measured PSU-DOE hydrogen values ( $\left.\mathrm{H}_{\text {measured }}\right)$ and predicted PSU-DOE hydrogen values $\left(\mathrm{H}_{\text {predicted }}\right)$. The predicted hydrogen values were calculated using equations described in table 13 (in text). The points represent individual PSU-DOE data records selected to have Mott-Spooner difference values within $\pm 250 \mathrm{Btu}$. Error bars illustrate an assay reproducibility of $\pm 0.3 \%$ hydrogen (ASTM, 2000b) and show that most of the scatter is explained by the precision of the hydrogen assay.

\section{Verification of ICR Net Heating Values}

The predicted hydrogen, estimated moisture, and measured Btu/lb values were used with equation 1 to calculate the average net heating value for 169 counties represented in the ICR data set. The county-average results show that the net heating value is about $4.5 \%$ less than the gross heating value. This is similar to the $5 \%$ difference assumed by the reference method to verify greenhouse gas emissions for the Kyoto Protocol (Houghton and others, 1997). However, as shown in figure 14, the difference between the net and gross heating value varies with coal rank. The net heating value of lignite is about 10 percent less than its gross heating value; the difference smoothly declines through the coalification series to reach a minimum ( 1 to $2 \%$ difference) at the anthracite stage. Figure 14 also shows that the net heating values predicted for 
the county-average ICR data mimic those calculated using the (measured) PSU-DOE moisture and hydrogen values.

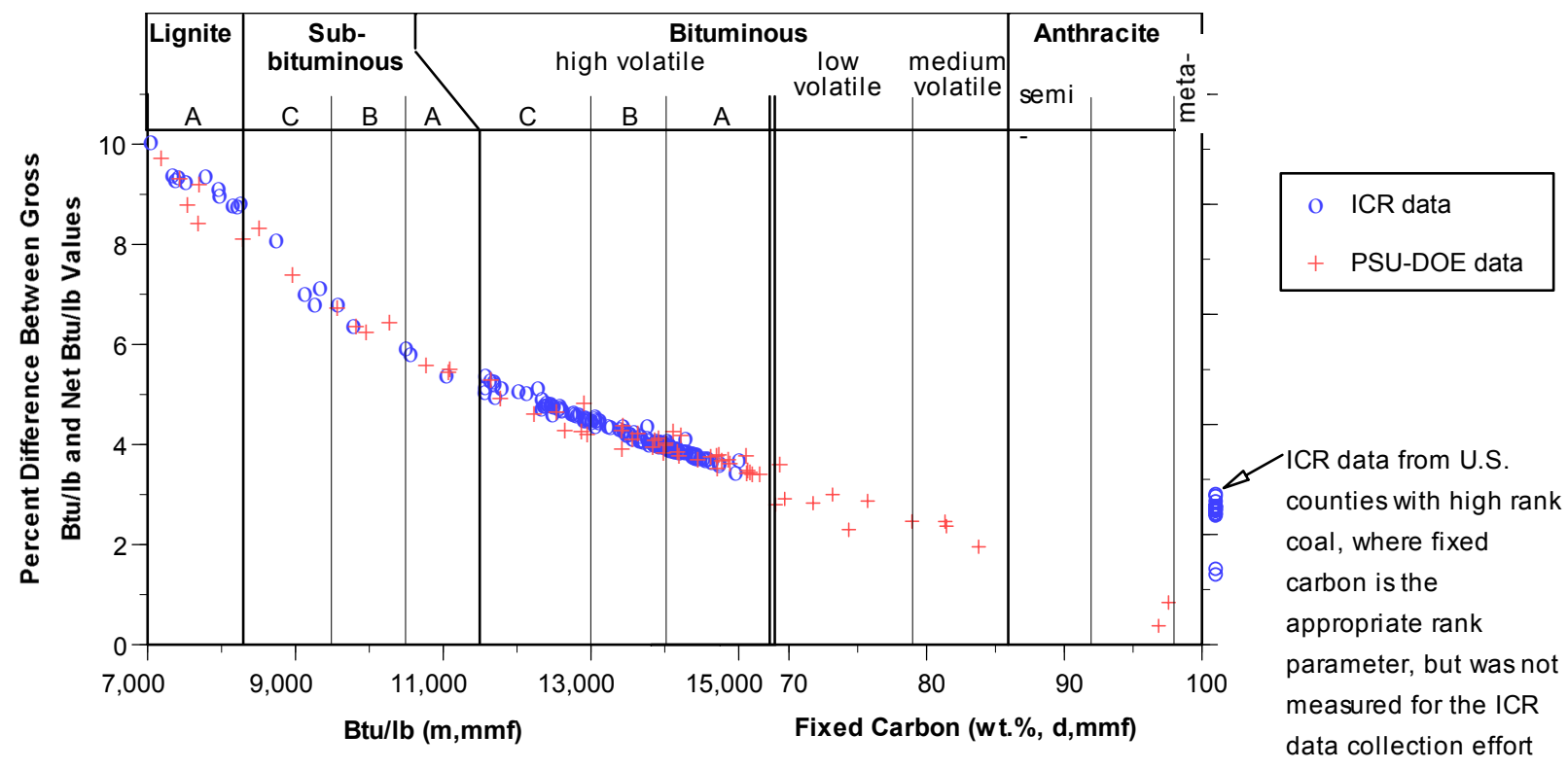

Figure 14. The difference between the net and gross heating value of U.S. coal from two data sets systematically varies with ASTM (1990) coal rank. The percent difference between the gross heating value of coal (Btugross), and the calculated net heating value $\left(B t u_{\text {net }}\right)$ corresponds to: Percent Difference $=\frac{100\left(B t u_{\text {gross }}-B t u_{n e t}\right)}{B t u_{\text {gross }}}$. The PSU-DOE data points represent single coal assays on an equilibrium moisture basis. The ICR data points represent county-average values on an estimated, as-shipped moisture basis.

\section{RESULTS AND DISCUSSION Data Evaluation}

County-average, moisture, ash, sulfur, and Btu/lb values for four data sets are compared in figures 15 and 16. Note that the data sets compared in figure 15 are populated by different numbers of counties, whereas the comparisons shown in figure 16 only include counties that are common to the ICR, and the FERC 423, CTRDB, or COALQUAL data sets. 


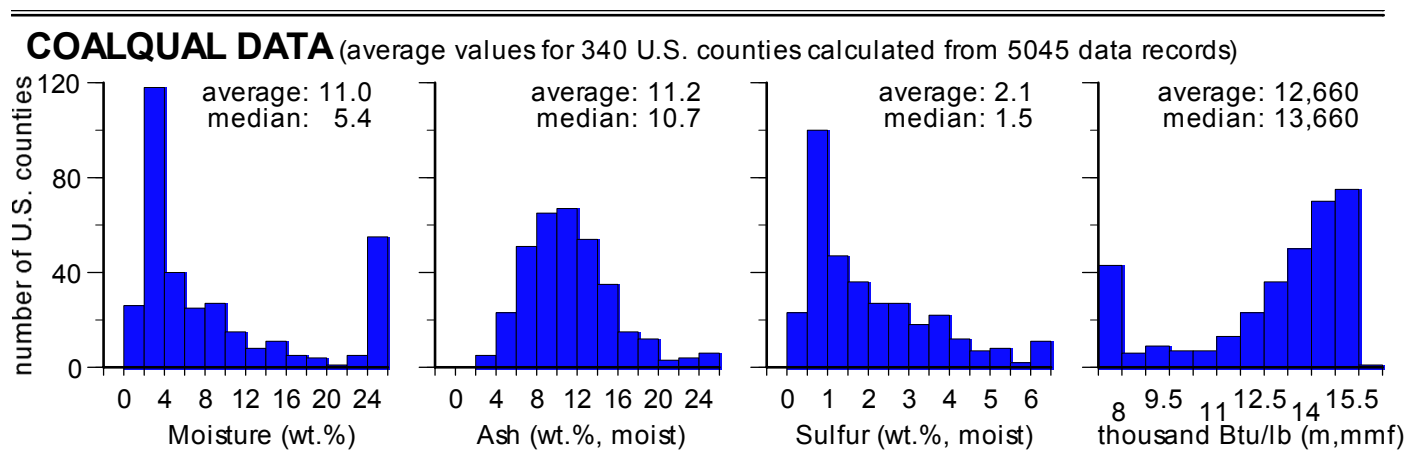

FERC 423 DATA (average values for 187 U.S. counties calculated from 19,507 data records)
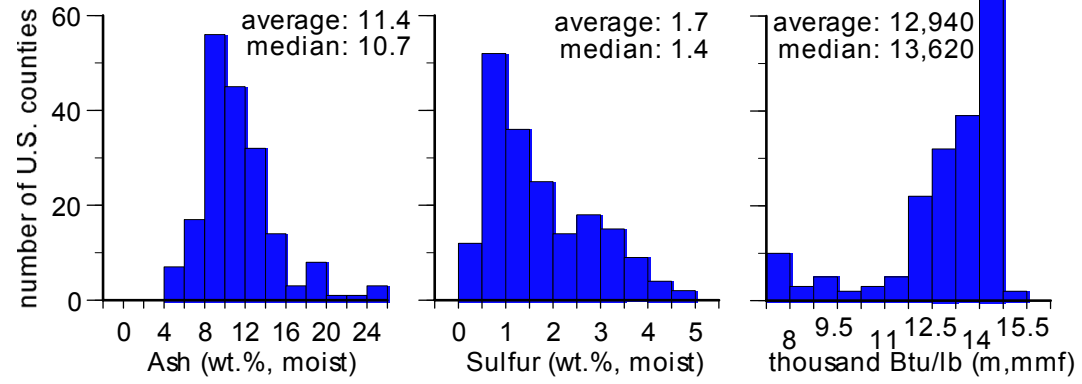

ICR DATA (average values for 169 U.S. counties calculated from 25,818 data records)
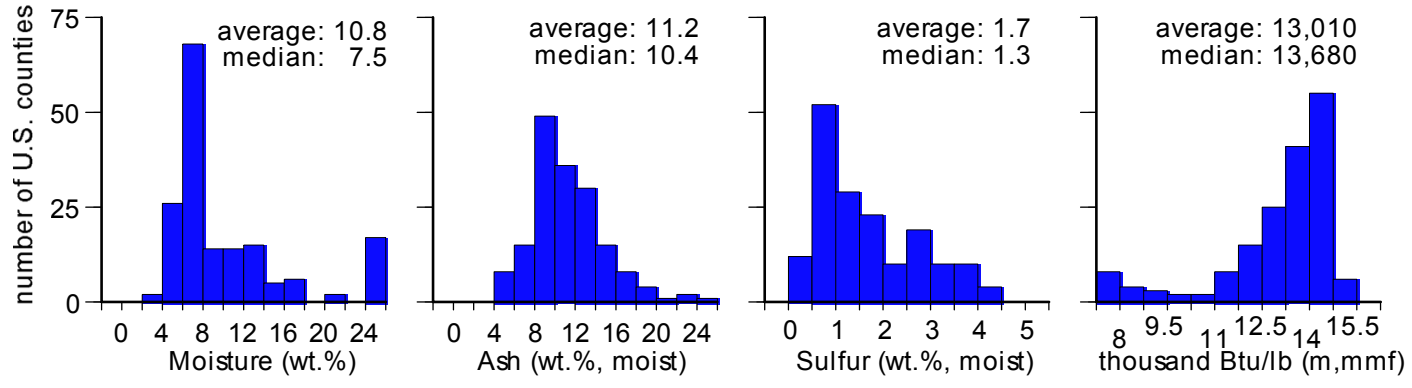

CTRDB DATA (average values for 116 U.S. counties calculated from 5,602 data records)
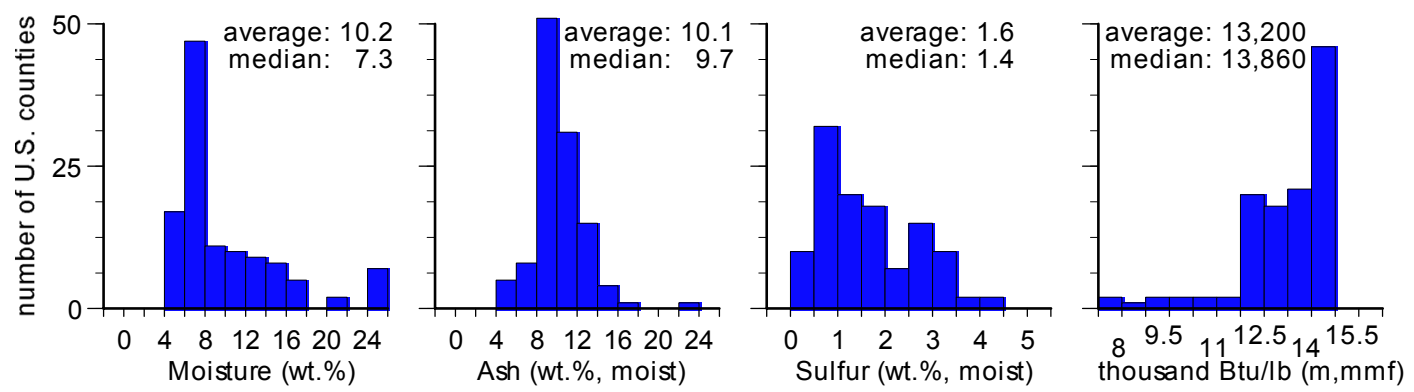

Figure 15. Histograms showing the distribution of county-average coal quality values for the COALQUAL, FERC 423, ICR, and CTRDB data sets. Moisture, ash, and sulfur values are expressed on a moist, whole-coal basis, whereas the Btu/lb values are expressed on a moist, mineral-matter-free basis, calculated after ASTM (1990). 

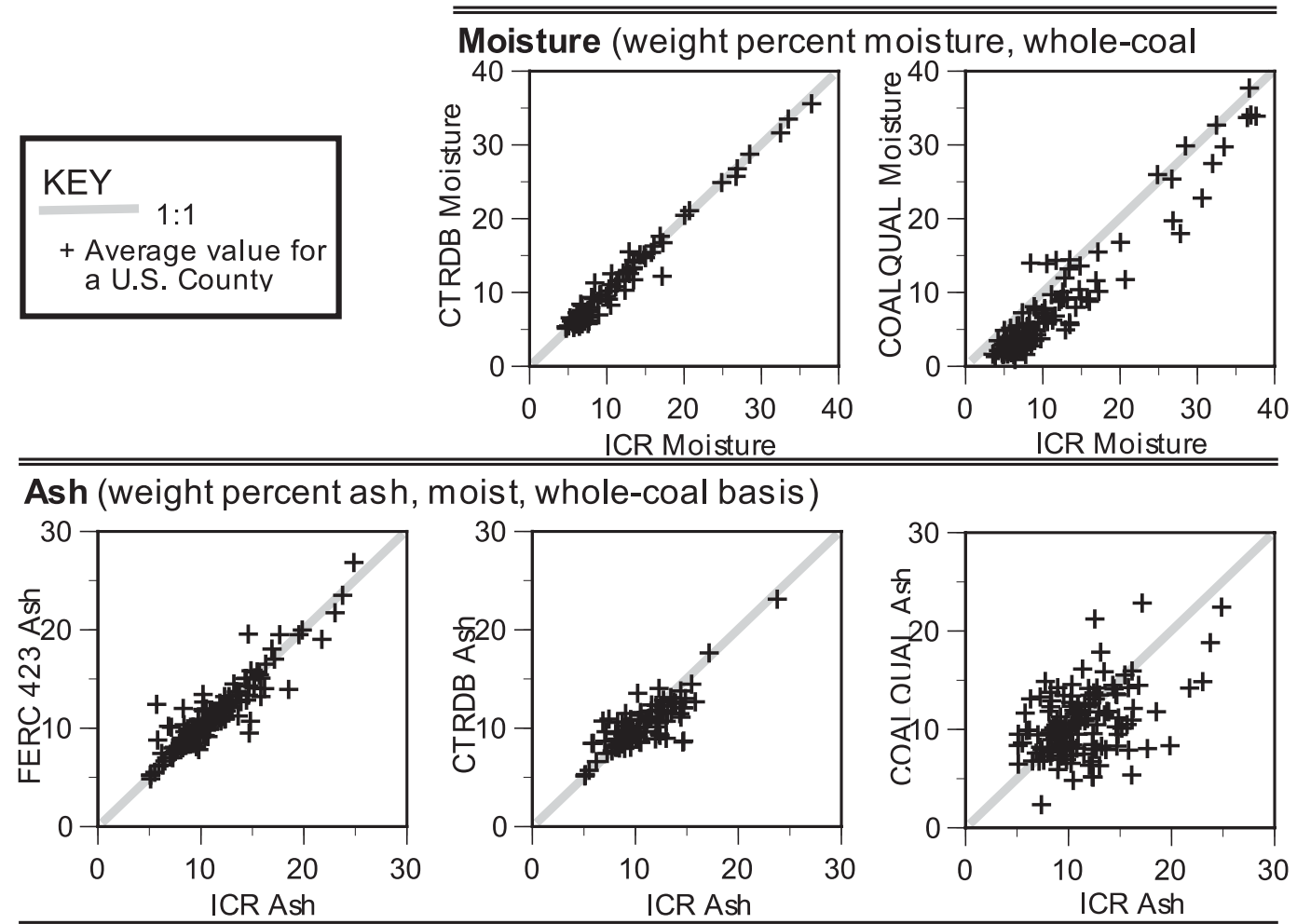

Sulfur (wieght percent sulfur, moist, whole-coal basis)
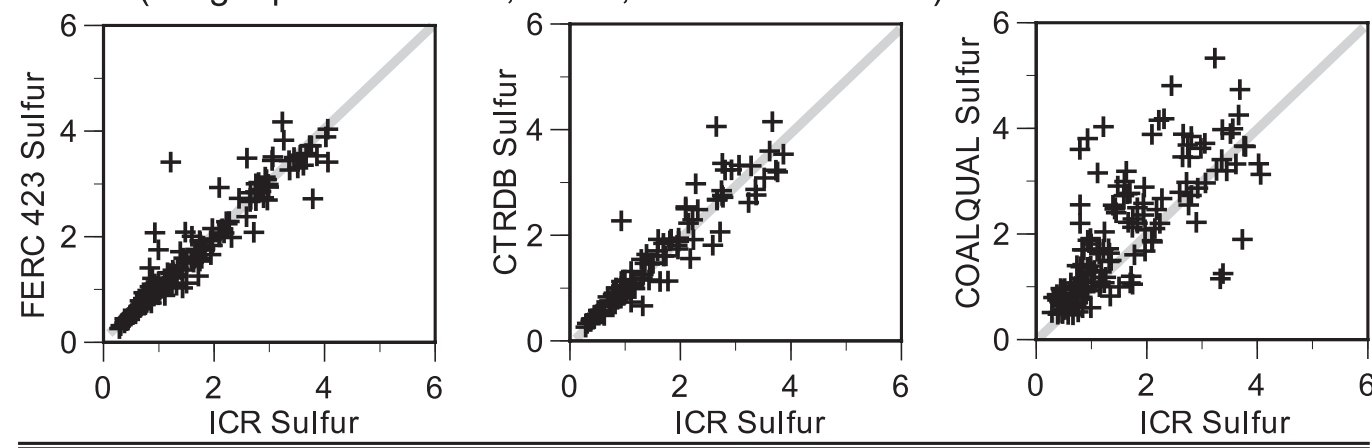

BTU (British thermal units per pound, moist, mineral-matter-free basis)
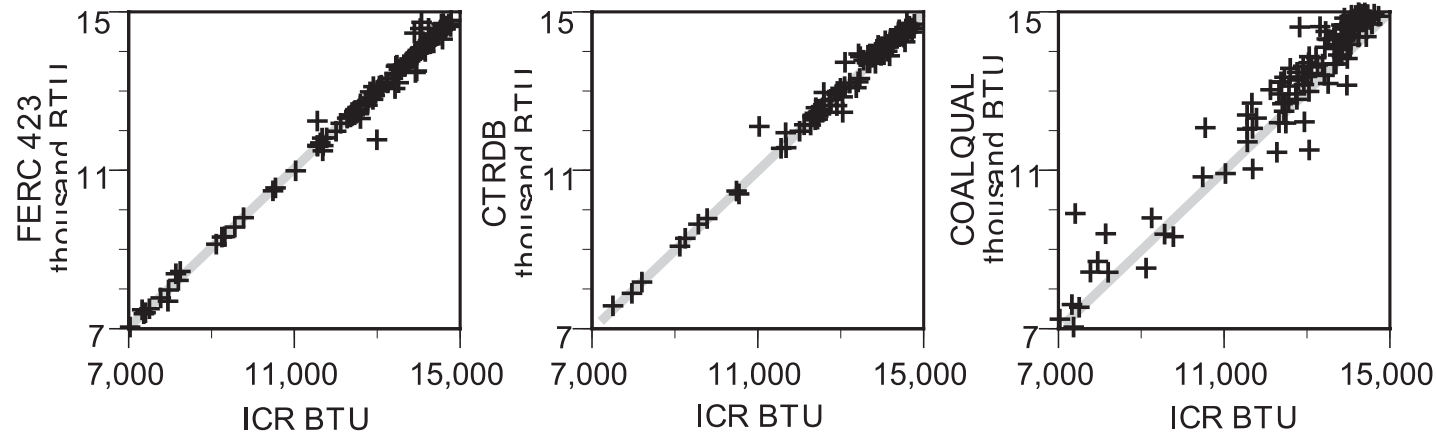

Figure 16. Cross-plots comparing the county-average moisture, ash, sulfur, and Btu/lb values from the ICR data set with those from the CTRDB, COALQUAL, and FERC 423 data sets; the Btu/lb values were calculated after ASTM (1990). 
Figures 15 and 16 show reasonably good agreement between the data sets, especially for data corresponding to commercial coal shipments (FERC 423, CTRDB, and ICR). The correlation between the ICR and FERC 423 sulfur values shown in figure 16 deserves comment. Despite the good correlation, a few counties deviate from the 1:1 line. Many of these deviations can be attributed to instances where the county-average values are calculated from one or two data records. However a few instances may indicate potential bias in ICR data. Given that the ICR data relied on periodic assays, and include a disproportionate number of records for small $(<50 \mathrm{MW})$ utilities, it is likely that the FERC 423 data better represent the quality of commercial U.S. coal than the ICR data. Moreover, sulfur exhibits a positive correlation with mercury for aggregated data (Quick and others, 2003). Consequently, instances where ICR sulfur is higher than FERC 423 sulfur may indicate erroneously high county-average ICR mercury values. Conversely, instances where the ICR sulfur is lower than the FERC 423 sulfur may indicate erroneously low county-average ICR mercury values.

The larger number of counties included in the COALQUAL data set should be considered when evaluating the data distributions shown in figure 15. For example, the relatively high, average moisture value for the 340 counties listed in the COALQUAL data set (figure 15) is a result of the comparatively large number of counties in the COALQUAL data set with high-moisture (low-rank) coal. Thus, the relatively high average COALQUAL moisture value shown in figure 15 is due to a geographic, rather than analytical, bias. Restricting the comparison of moisture values to common counties (figure 16) shows that the COALQUAL assay moisture values are actually relatively low. Although the relatively low COALQUAL moisture values may relate to added moisture from washing of commercial coal (ICR and CTRDB data), moisture loss prior to analysis of the COALQUAL coal samples is probably more 
significant. Indeed, Bragg and others (1997) noted that the calculated ASTM rank for some COALQUAL data records might be anomalously high due to air-drying of the samples before analysis. The low COALQUAL moisture values due to assay bias are also consistent with the relatively high, moist-basis COALQUAL Btu/lb values (figure 16).

As noted earlier in this report, systematically low COALQUAL moisture values complicate the evaluation of rank and the calculation of net heating values. Fortunately, the low moisture values have little effect on COALQUAL emission factors expressed on an energy basis. For example, the calculation of pounds sulfur per million Btu gives the same result regardless of whether moist-basis sulfur and Btu/lb values, or dry-basis sulfur and Btu/lb values, are used for the calculation. Figures 17 and 18 compare ICR sulfur, mercury, and chlorine values expressed on an energy-basis to equivalent COALQUAL values.
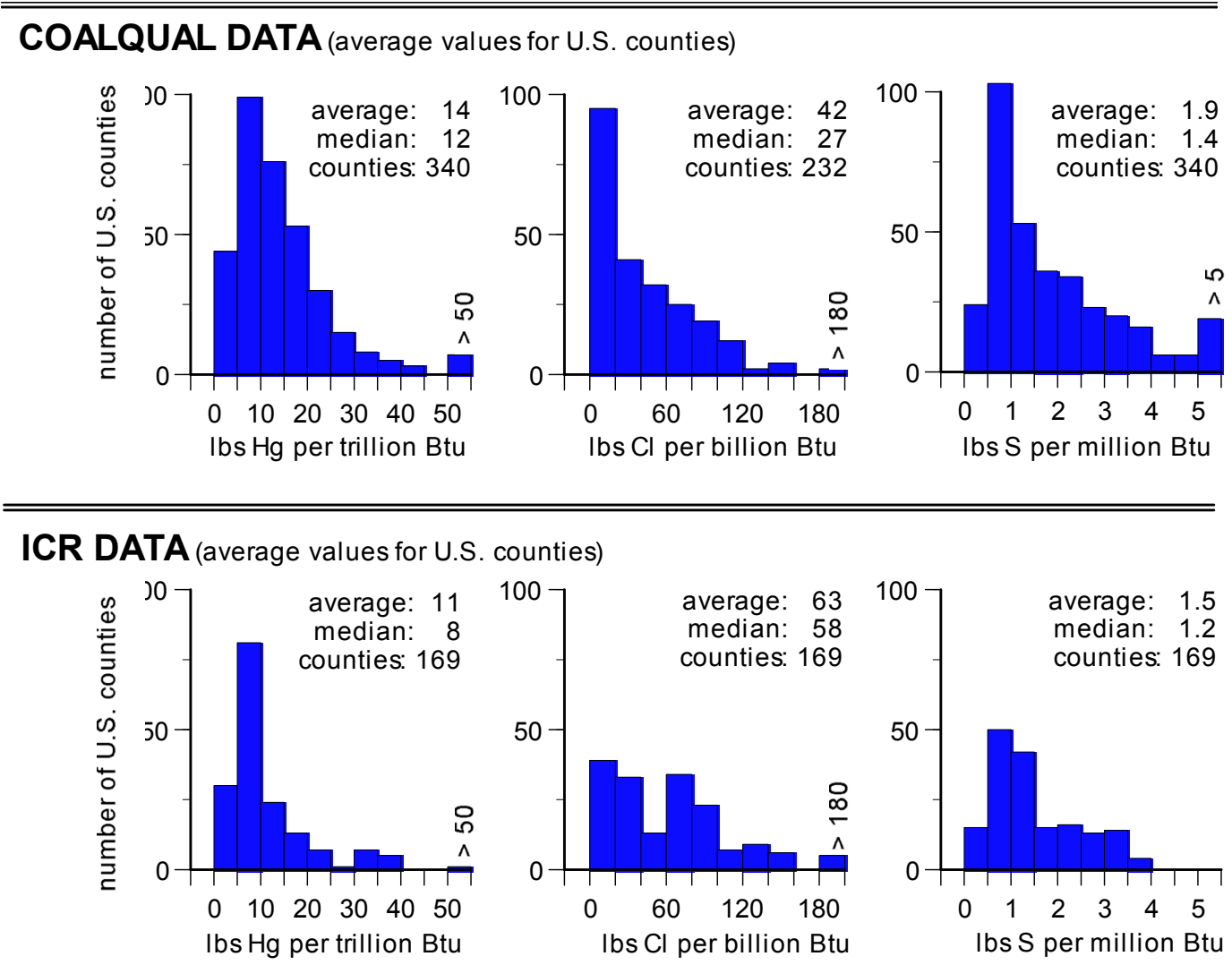

Figure 17. Distribution of county-average, mercury, chlorine and sulfur values for in-ground coal (COALQUAL DATA) and commercial coal (ICR DATA). 

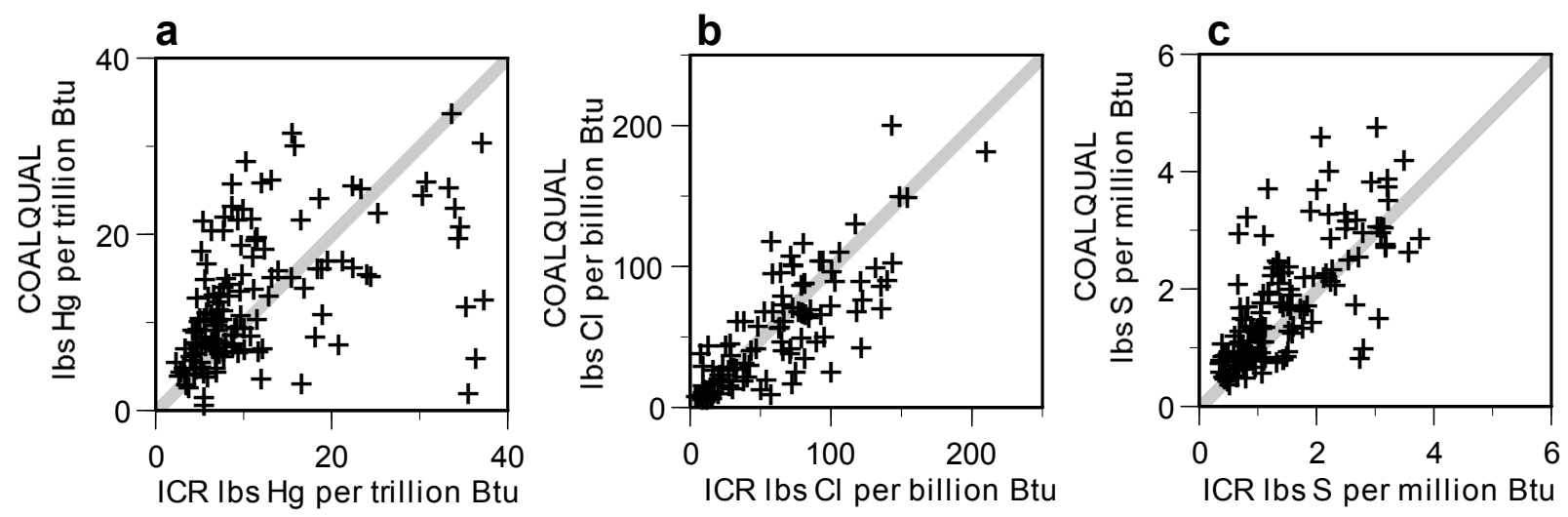

\section{KEY}

+ average value for

a U.S. county

Figure 18. Comparison of mercury, chlorine, and sulfur values in the ICR and COALQUAL data sets. Data points show average values for U.S. counties common to both data sets.

When examining figures 17 and 18 it is useful to recognize that the COALQUAL data indicate the quality of the in-ground coal resource, whereas the ICR data indicate the quality of commercial coal produced during 1999. Differences between the COALQUAL and ICR data are inevitable because the COALQUAL data include additional records for coal beds that are not mined. Nonetheless, comparison of these data is instructive. Figure 17 shows higher sulfur and mercury values for the COALQUAL data than the ICR data. Quick and others (2003) also observed higher COALQUAL sulfur and mercury values, which they attributed to selective mining of low-sulfur and low-mercury coal, as well as reduction of sulfur and mercury due to washing of mined coal. However, figure 18a shows that the mercury content of in-ground coal (COALQUAL data) is not always higher than the mercury content of commercially shipped coal (ICR data) when the comparison is restricted to coal from common counties-of-origin. Counties where the mined coal contains more mercury than indicated by the COALQUAL data are colored red in figure 19. The reason for the higher mercury content of coal mined in these areas 
may be the combined result of limited washing, and contamination of mined coal by highmercury partings, roof rock, or floor rock; these contaminants are generally not included in COALQUAL assay specimens because USGS sample collections guidelines (Swanson and Huffman, 1976) require partings more than $5 \mathrm{~mm}$ thick to be excluded from the analysis sample. Increased coal washing may be an effective Hg reduction strategy in instances where the ICR mercury values are greater than the COALQUAL mercury values. Blue areas on figure 19 show where mined coal contains substantially less Hg than the in-ground resource. Selective mining and/or extensive coal washing probably explain these occurrences. For a few counties, these differences may simply indicate bias in the ICR data (suggested by the different FERC 423 and ICR sulfur values, discussed above) or instances where the county average values are based on only a few data records.

The different chlorine distributions for the COALQUAL and ICR data shown in figure 17 suggest preferential mining of counties with high-chlorine coal. However, such inferences are uncertain given the limitations of the chlorine assays. For example, nearly $30 \%$ of the COALQUAL chlorine values are reportedly below the assay detection limit (Bragg and others, 1997). Although only $14 \%$ of the selected ICR records are reportedly below the detection limit, this is probably a minimum value. Nyberg (2003) noted that methods used to determine chlorine concentrations in the ICR data collection effort were unreliable below 200 parts-per-million (ppm or $\mu \mathrm{g} / \mathrm{g}$ ). Thirty percent of the selected ICR data records show dry chlorine at or below $200 \mathrm{ppm}$. Moreover, figure 20 shows that western U.S. counties are responsible for a disproportionate share of the low-chlorine ICR data records. 


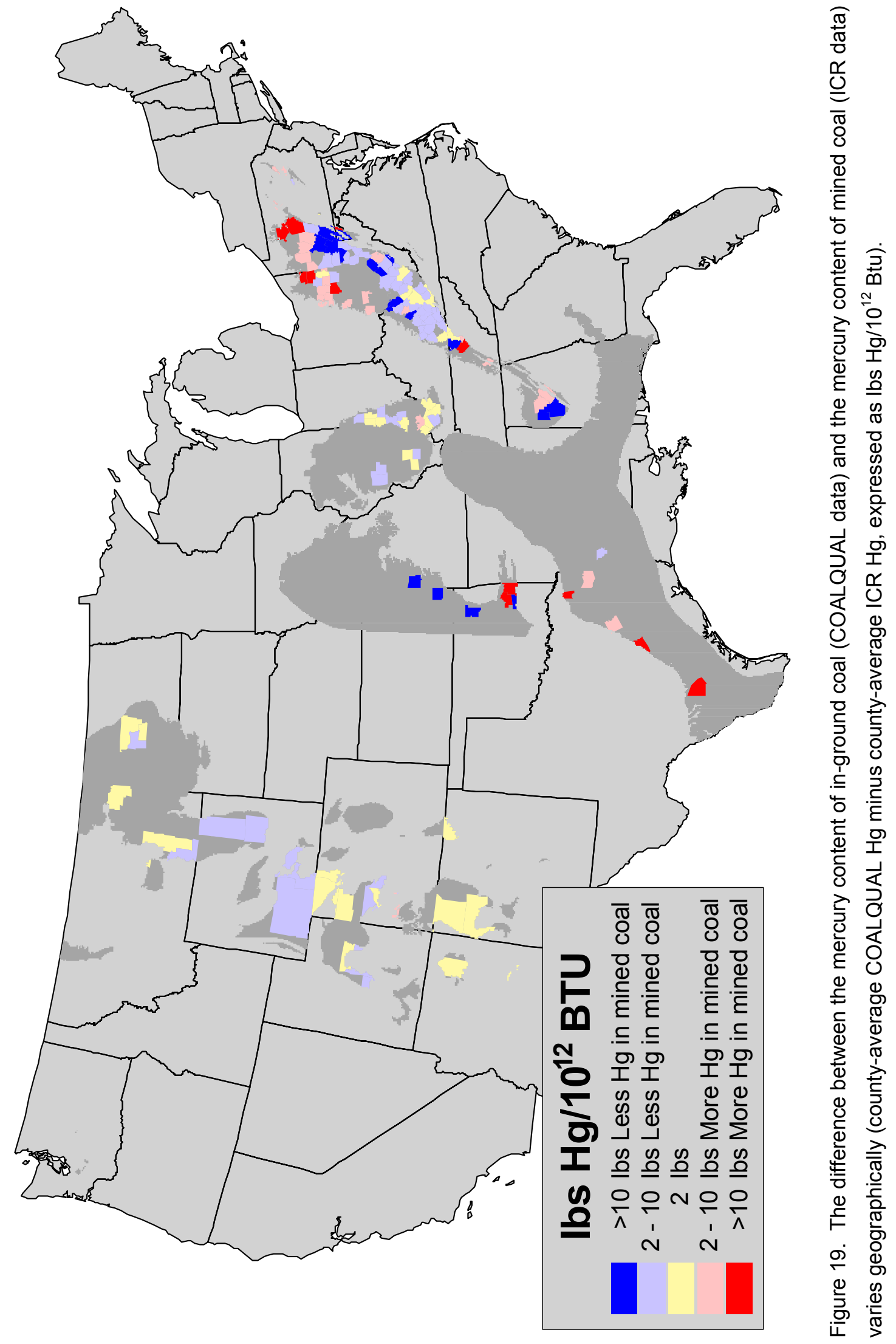




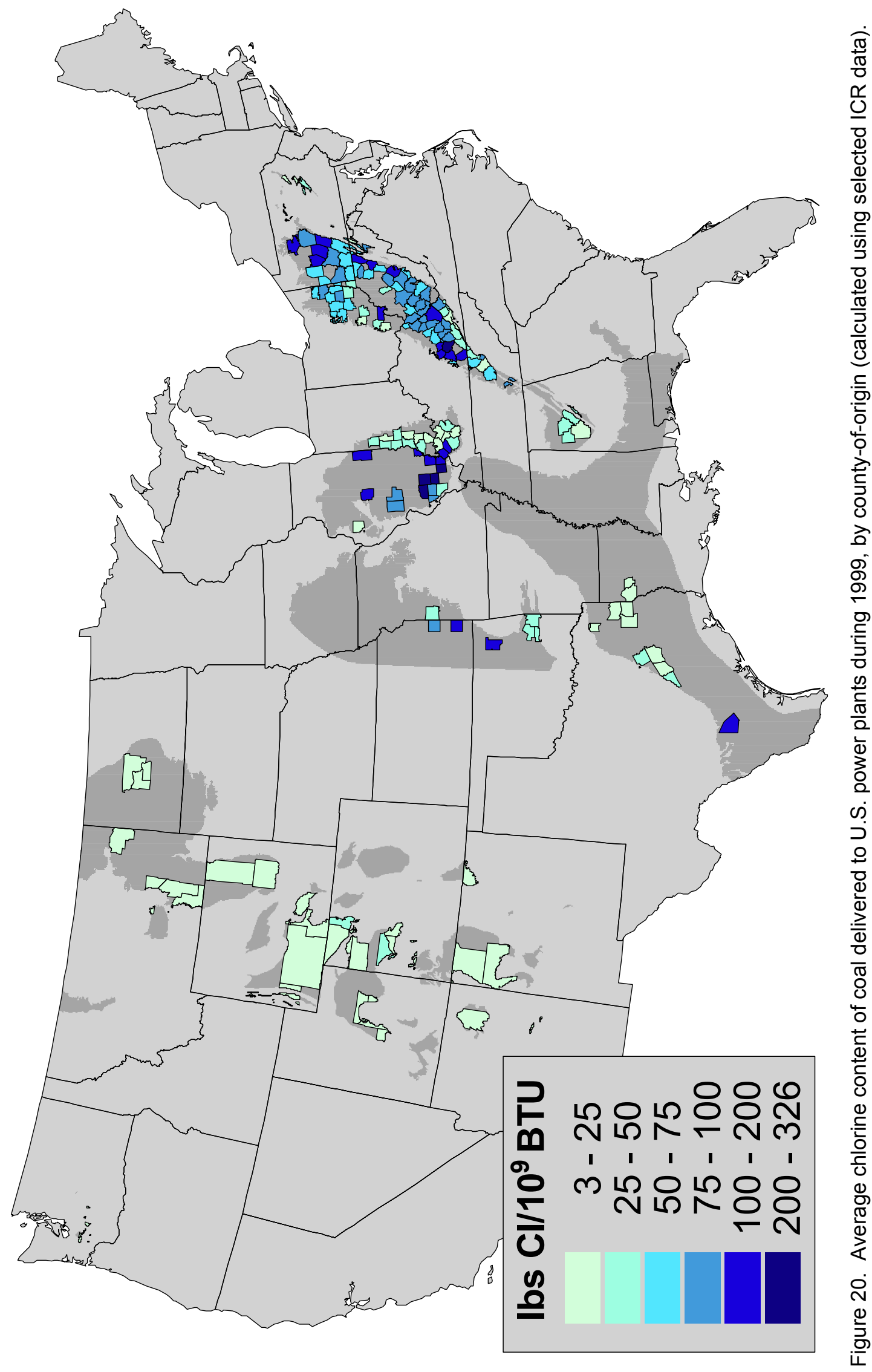




\section{Mercury Capture by Existing Emission Controls}

The ICR part 3 data set (USEPA, 2003) includes mercury stack gas measurements from about 80 selected U.S. power plants that were collected for part 3 of the 1999 information collection request. The data show measured mercury emissions and allow calculation of boiler heat inputs from flue gas volume using the F-factor (Stultz and Kitto, 1992). Various groups have used the ICR 3 utility emission data to derive equations that predict mercury capture for existing emission control technologies (Chu and others, 2000; Laumb and others, 2000; Roberson, 2002; ENSR, 2003; SAIC, 2003; AEMS, 2004). The equations use coal chlorine, ash, Btu, or sulfur values as independent variables to predict mercury capture by different emission control technologies.

Table 14 lists three different equations for each of the (five) emission control technologies examined in this study. Figures $21,22,23,24$, and 25 compare the mercury capture predicted by these equations for each control technology. Note the similar $r^{2}$ values, similar trends, but different results, for all five of the control technologies examined in this study (cESP, hESP, hESP/FGD, cESP/FGD, and SDA/FF controls). 
Table 14. Technology-specific equations that predict mercury capture.

\begin{tabular}{|c|c|c|c|}
\hline $\begin{array}{l}\text { TECHNOLOGY } \\
\text { Reference }\end{array}$ & Equation to Predict Mercury Capture $(100 \%$ capture $=1)$ & $r^{2}$ & $\mathrm{n}$ \\
\hline \multicolumn{4}{|l|}{ cESP } \\
\hline \multirow{2}{*}{ Roberson $(2002)^{1}$} & \multirow{2}{*}{$0.1233 L n\left(\frac{C l_{p p m, d r y}}{1.998 S_{l b s / 10^{6} B t u}}\right)-0.3885$} & \multirow{2}{*}{0.53} & \multirow{2}{*}{28} \\
\hline & & & \\
\hline model 2, SAIC (2003) & $1-\operatorname{Exp}\left(-7.33 E^{-2}-3.309\left(\right.\right.$ Ibs Cl per $\left.\left.10^{12} B t u\right)\right)$ & 0.47 & 12 \\
\hline model 1 , SAIC (2003) & $1-\operatorname{Exp}\left(1.6374-0.18693 \operatorname{Ln}\left(\right.\right.$ Ibs Cl per $\left.\left.10^{12} \mathrm{Btu}\right)\right)$ & 0.38 & 12 \\
\hline \multicolumn{4}{|l|}{ cESP/FGD } \\
\hline Roberson (2002) & $0.1157 \operatorname{Ln}\left(C l_{p p m, d r y}\right)-0.1438$ & 0.70 & 11 \\
\hline model 1 , SAIC (2003) & $1-\operatorname{Exp}\left(1.8529-0.27149 \operatorname{Ln}\left(\right.\right.$ Ibs Cl per $\left.\left.10^{12} B t u\right)\right)$ & 0.74 & 8 \\
\hline model 3, SAIC (2003) & $1-\operatorname{Exp}\left(-0.2559-2.3343 E^{-5}\left(\frac{100 C l_{p p m, d r y}}{S_{w t . \%, d r y}}\right)\right)$ & 0.73 & 8 \\
\hline \multicolumn{4}{|l|}{ hESP } \\
\hline model 1 , SAIC (2003) & $1-\operatorname{Exp}\left(0.9451-9.995 E^{-2} \operatorname{Ln}\left(\right.\right.$ lbs Cl per $\left.\left.10^{12} \mathrm{Btu}\right)\right)$ & 0.42 & 7 \\
\hline model 3, SAIC (2003) & $1-\operatorname{Exp}\left(0.0611-2.169 E^{-6}\left(\frac{100 C l_{p p m, d r y}}{S_{w t . \%, d r y}}\right)\right)$ & 0.54 & 7 \\
\hline ENSR (2003) & $1-\operatorname{Exp}\left(0.12124-1.021 E^{-4}\left(C l_{p p m, d r y}\right)\right)$ & 0.39 & 9 \\
\hline \multicolumn{4}{|l|}{ hESP/FGD } \\
\hline model 1 , SAIC (2003) & $1-\operatorname{Exp}\left(2.7019-0.29952 \operatorname{Ln}\left(\right.\right.$ Ibs Cl per $\left.\left.10^{12} \mathrm{Btu}\right)\right)$ & 0.75 & 6 \\
\hline model 2, SAIC (2003) & $1-\operatorname{Exp}\left(-3.59 E^{-2}-9.358 E^{-6}\left(\right.\right.$ Ibs Cl per $\left.\left.10^{12} \mathrm{Btu}\right)\right)$ & 0.67 & 6 \\
\hline model 4, SAIC (2003) & $1-\operatorname{Exp}\left(2.5618-0.268 L n\left(\frac{100 C l_{p p m, d r y}}{S_{w t . \%, d r y}}\right)\right)$ & 0.42 & 6 \\
\hline \multicolumn{4}{|l|}{ SDA/FF } \\
\hline Roberson (2002) & $0.2854 \operatorname{Ln}\left(C l_{p p m, d r y}\right)-1.1302$ & 0.91 & 10 \\
\hline model 1 , SAIC (2003) & $1-\operatorname{Exp}\left(10.7111-1.22628 \operatorname{Ln}\left(\right.\right.$ Ibs Cl per $\left.\left.10^{12} B t u\right)\right)$ & 0.89 & 10 \\
\hline ENSR (2003) & $1-\operatorname{Exp}\left(-0.19992-2.164 E^{-3}\left(C l_{p p m, d r y}\right)\right)$ & 0.94 & 10 \\
\hline
\end{tabular}

Notes, ${ }^{1}$ corrected after EPRI (2000)

cESP: cold-side Electrostatic Precipitator;

cESP/FGD: cold-side Electrostatic Precipitator with wet Flue Gas Desulphurization; hESP: hot-side Electrostatic Precipitator;

hESP/FGD: hot-side Electrostatic Precipitator with wet Flue Gas Desulphurization; SDA/FF: Spray Dry Adsorption with Fabric Filter. 

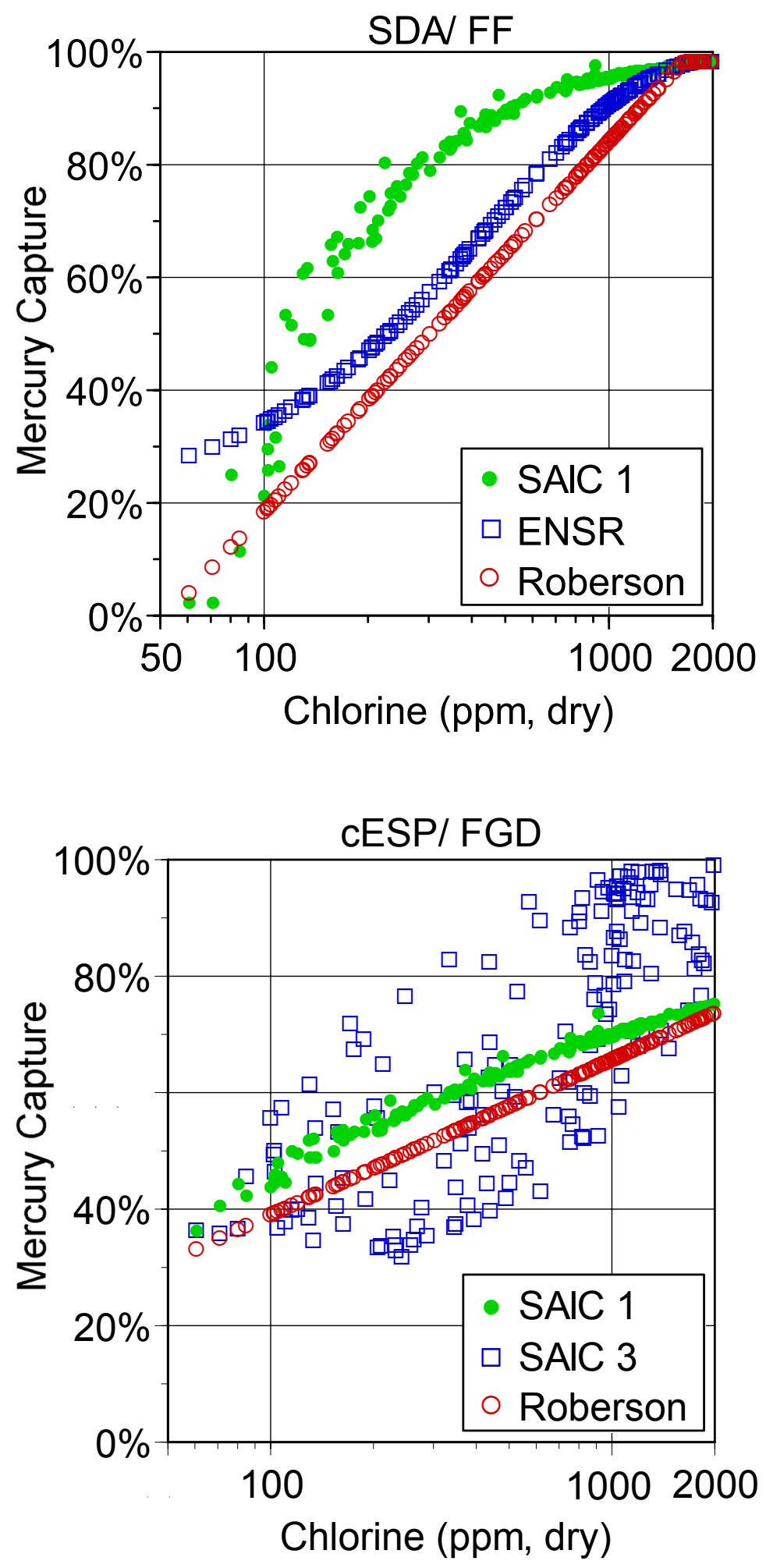

Figure 21. Three equations predict different amounts of mercury capture for SDA/FF technology when applied to data for 162 U.S. counties.

Notes, SDA/FF: Spray Dry Adsorption, Fabric Filter; SAIC (2003), ENSR (2003), and Roberson (2002) equations listed on table 14 (this report); ICR countyaverage coal assay data (appendix); results for six counties with $>2000$ ppm chlorine and one county with $<50$ ppm chlorine are not shown; results limited to $2 \%$ minimum capture and $98 \%$ maximum capture.

Figure 22. Three equations predict different amounts of mercury capture for cESP/FGD technology when applied to data for 162 U.S. counties.

Notes, cESP/FGD: cold-side Electrostatic Precipitator, wet Flue Gas Desulphurization; SAIC (2003), and Roberson (2002) equations listed on table 14 (this report); ICR county-average coal assay data (appendix); results for six counties with $>2000 \mathrm{ppm}$ chlorine and one county with $<50$ ppm chlorine are not shown; results limited to $2 \%$ minimum capture and 98\% maximum capture. 

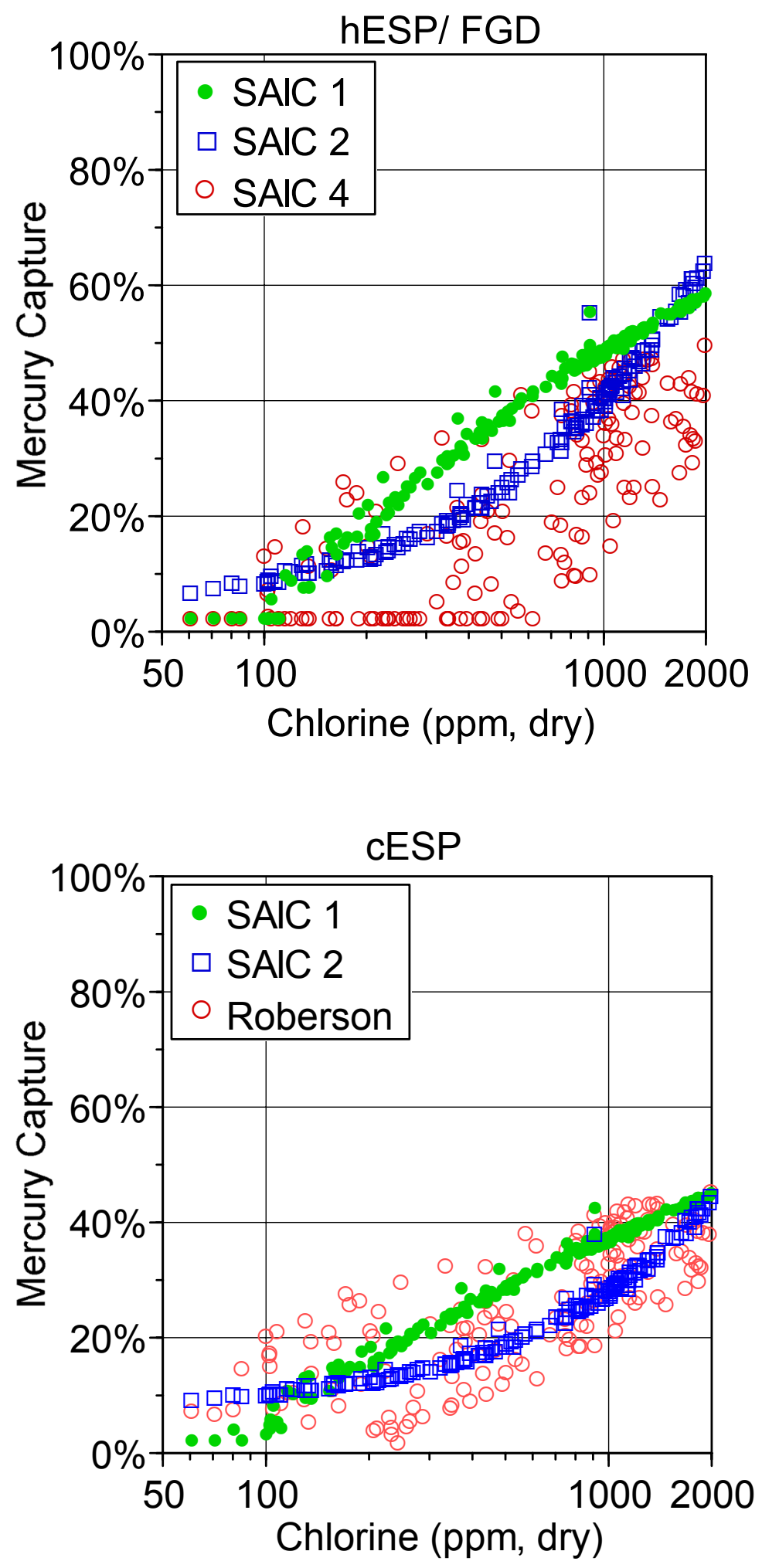

Figure 23. Three equations predict different amounts of mercury capture for hESP/FGD technology when applied to data for 162 U.S. counties.

Notes, hESP/FGD: hot-side

Electrostatic Precipitator, wet Flue Gas Desulphurization; SAIC (2003) equations listed on table 14 (this report); ICR county-average coal assay data (appendix); results for six counties with $>2000 \mathrm{ppm}$ chlorine and one county with $<50$ ppm chlorine are not shown; results limited to $2 \%$ minimum capture and 98\% maximum capture.

Figure 24. Three equations predict different amounts of mercury capture for cESP technology when applied to data for 162 U.S. counties.

Notes, cESP: cold-side Electrostatic Precipitator; SAIC (2003), and Roberson (2002) equations listed on table 14 (this report); ICR countyaverage coal assay data (appendix); results for six counties with $>2000$ ppm chlorine and one county with $<50$ ppm chlorine are not shown; results limited to $2 \%$ minimum capture and $98 \%$ maximum capture. 


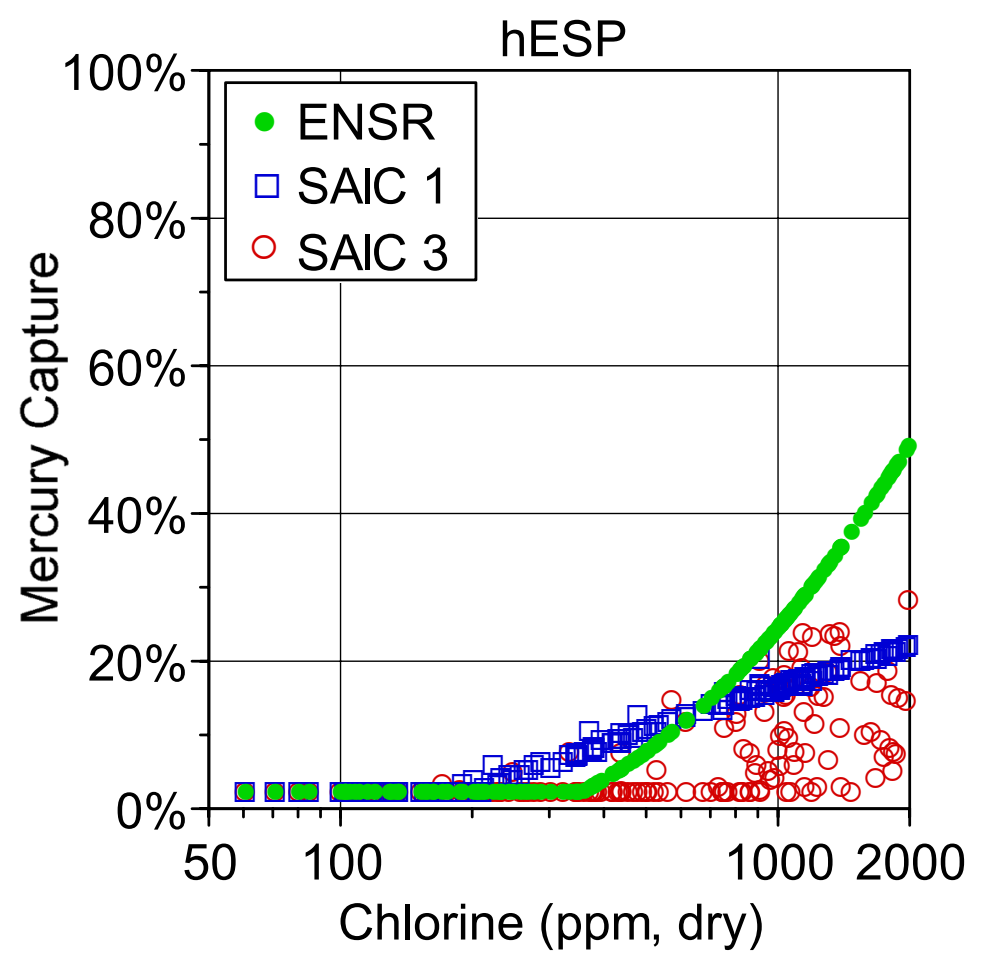

Figure 25. Three equations predict different amounts of mercury capture for hESP technology when applied to data for 162 U.S. counties.

Notes, hESP: hot-side Electrostatic Precipitator; ENSR (2003) and SAIC (2003) equations listed on table 14 (this report); ICR countyaverage coal assay data (appendix); results for six counties with $>2000$ ppm chlorine and one county with $<50$ ppm chlorine are not shown; results limited to $2 \%$ minimum capture and $98 \%$ maximum capture.

The similar statistical significance but different county-specific results for the equations listed in table 14, coupled with the lack of a verification data set, makes selection of the best equation for each technology group largely arbitrary. Lacking objective criteria to select a single best equation, we chose to use the average result obtained from all three equations.

We applied all of the equations listed in table 14 to the county-average coal quality values from the ICR data set and averaged the result for each of the five technologies groups. The results are graphically compared in figure 26, and illustrated in figures 27 through 36 . 


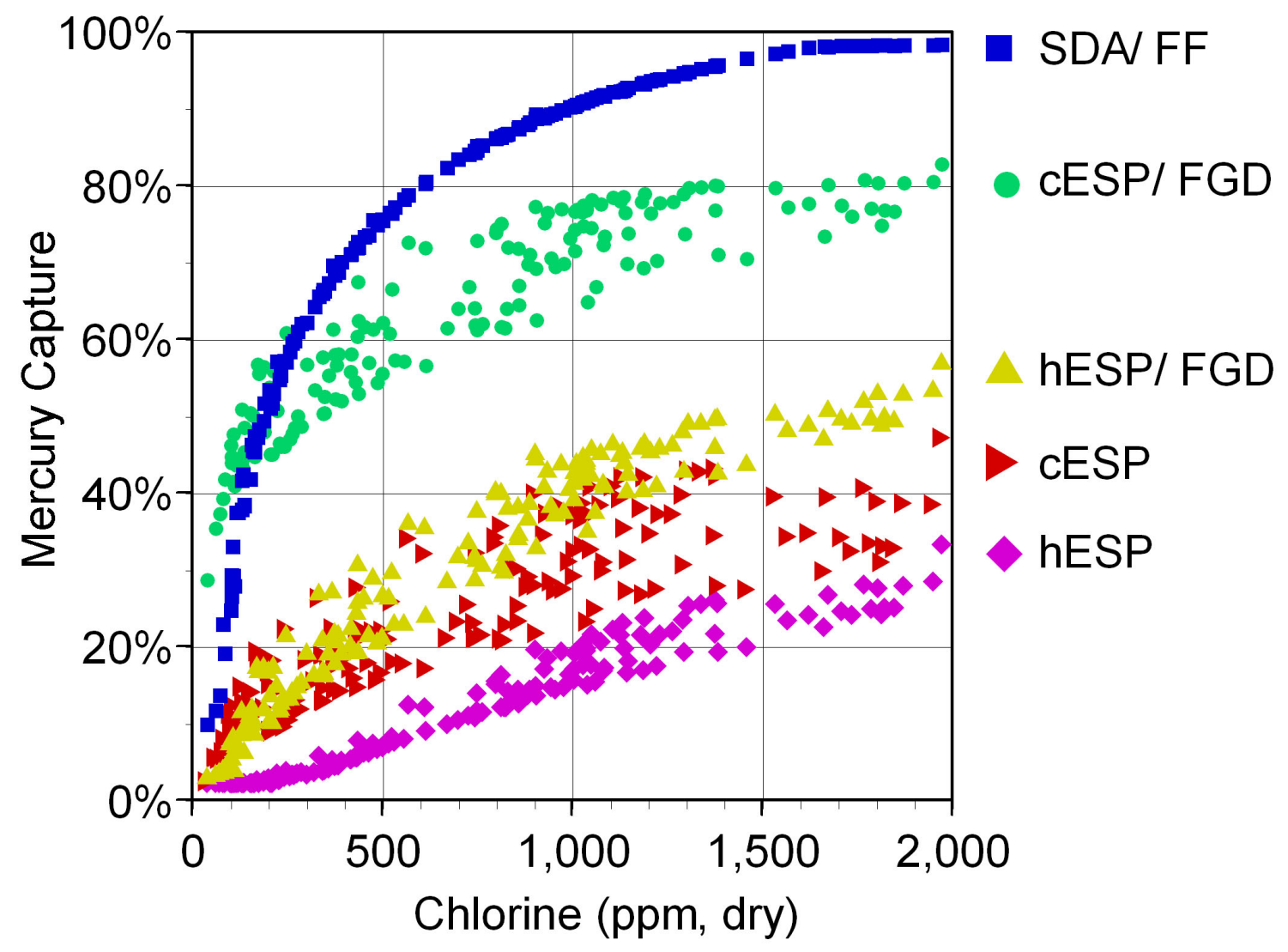

Figure 26. Mercury capture predicted for 162 U.S. counties increases with increasing coal chlorine for five existing control technologies. Mercury capture is the average result of three equations for each control technology applied to county-average, ICR coal assay values. The equations are listed in table 14 (this report); county-average ICR assay values are listed the appendix. 


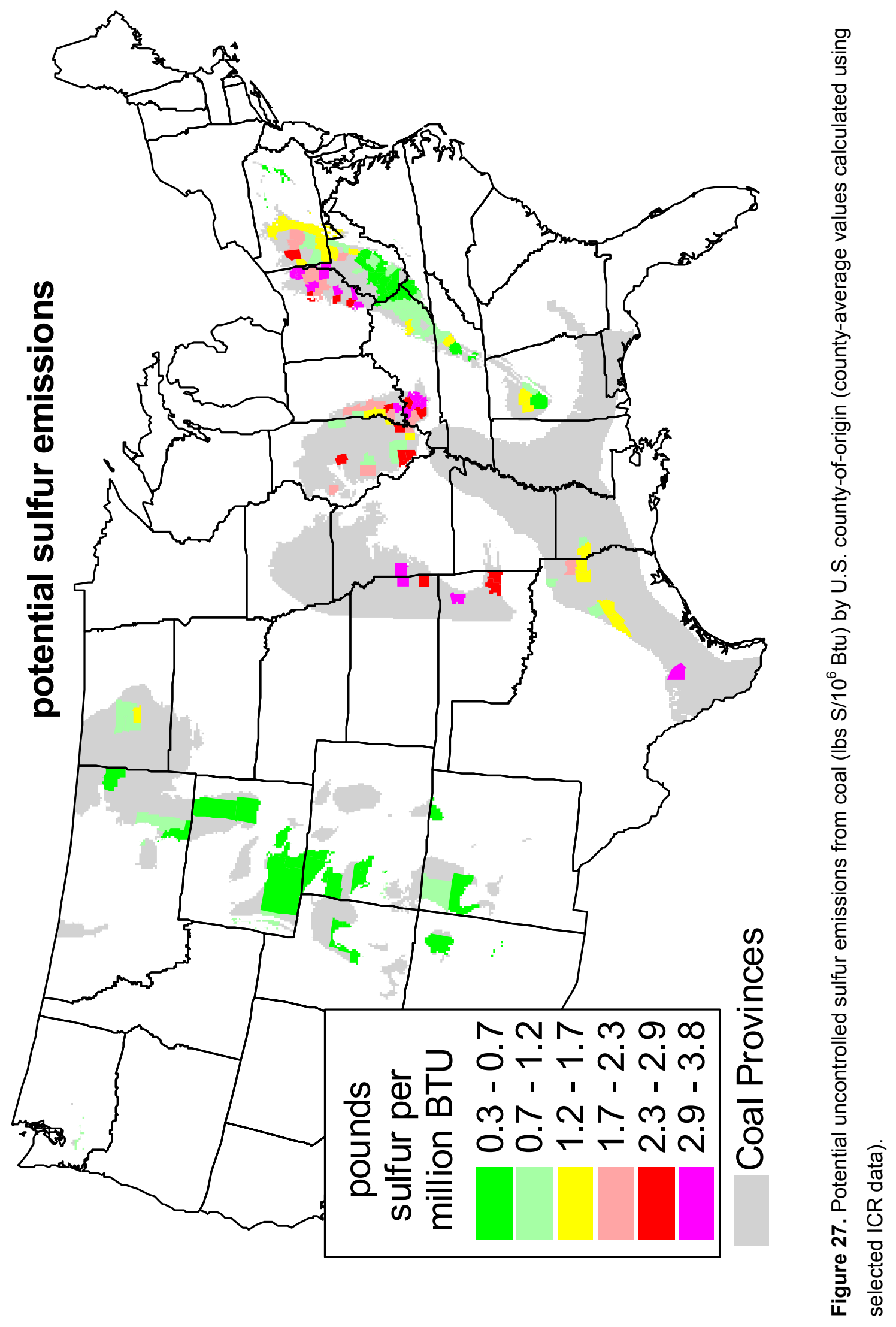




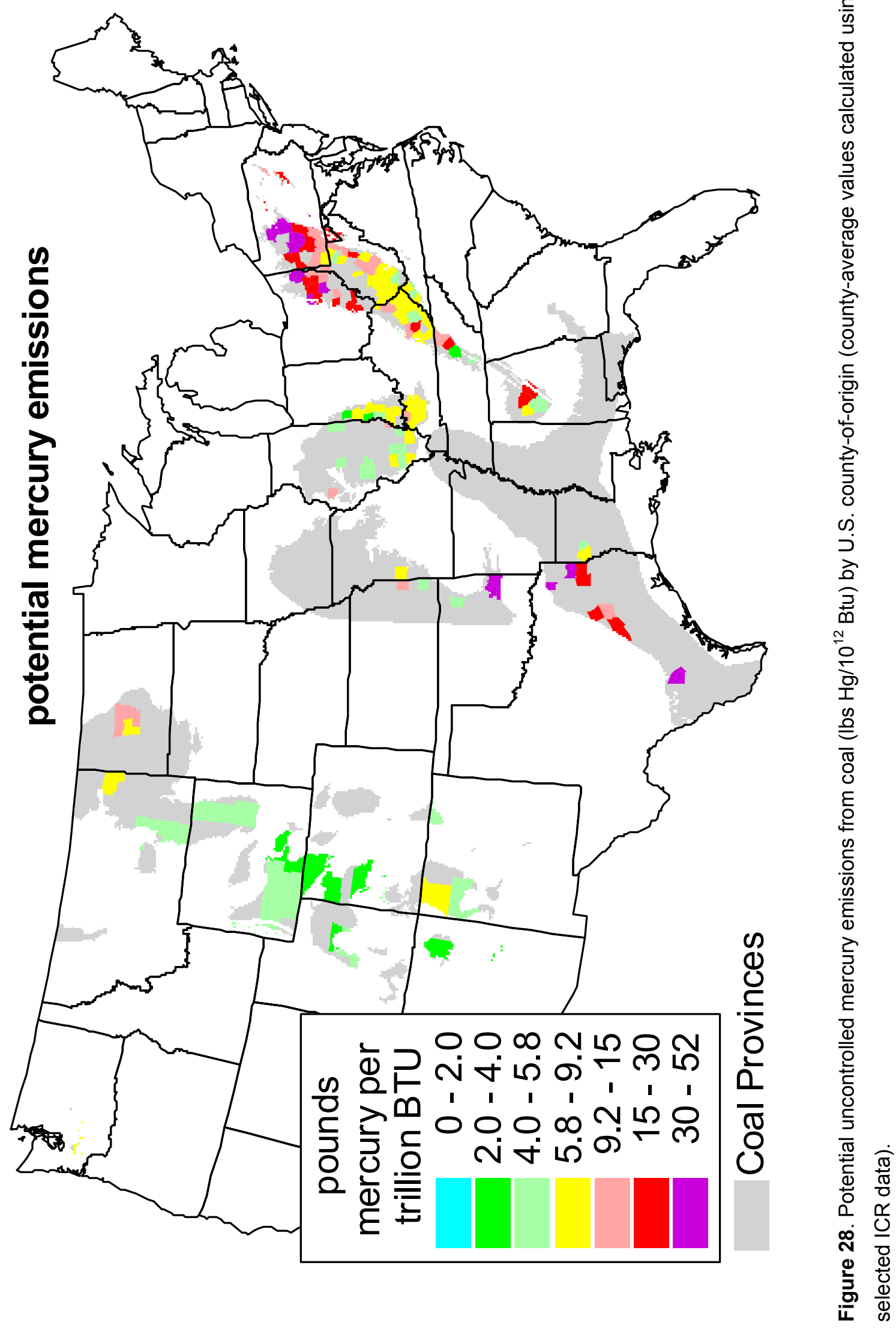




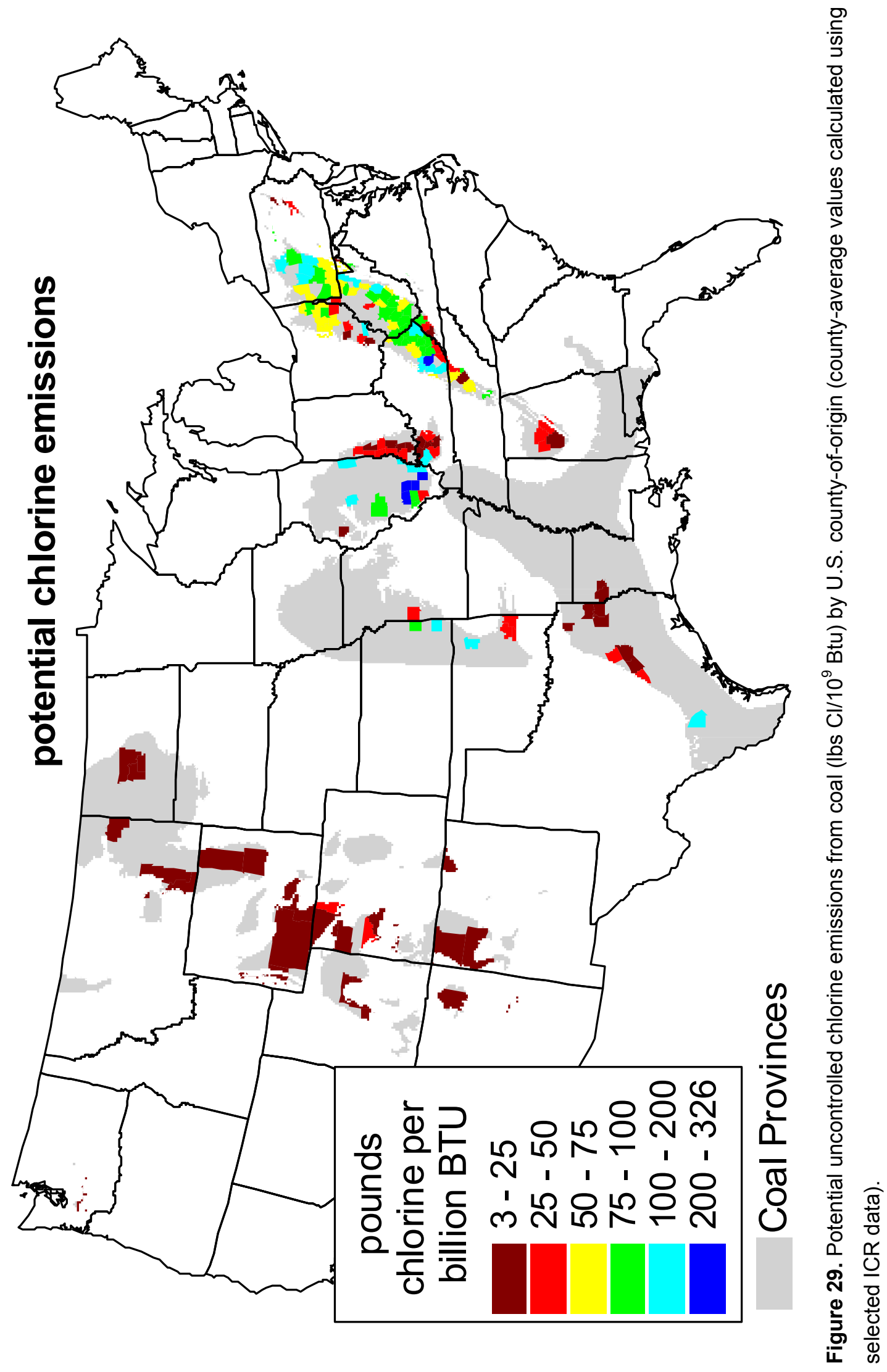




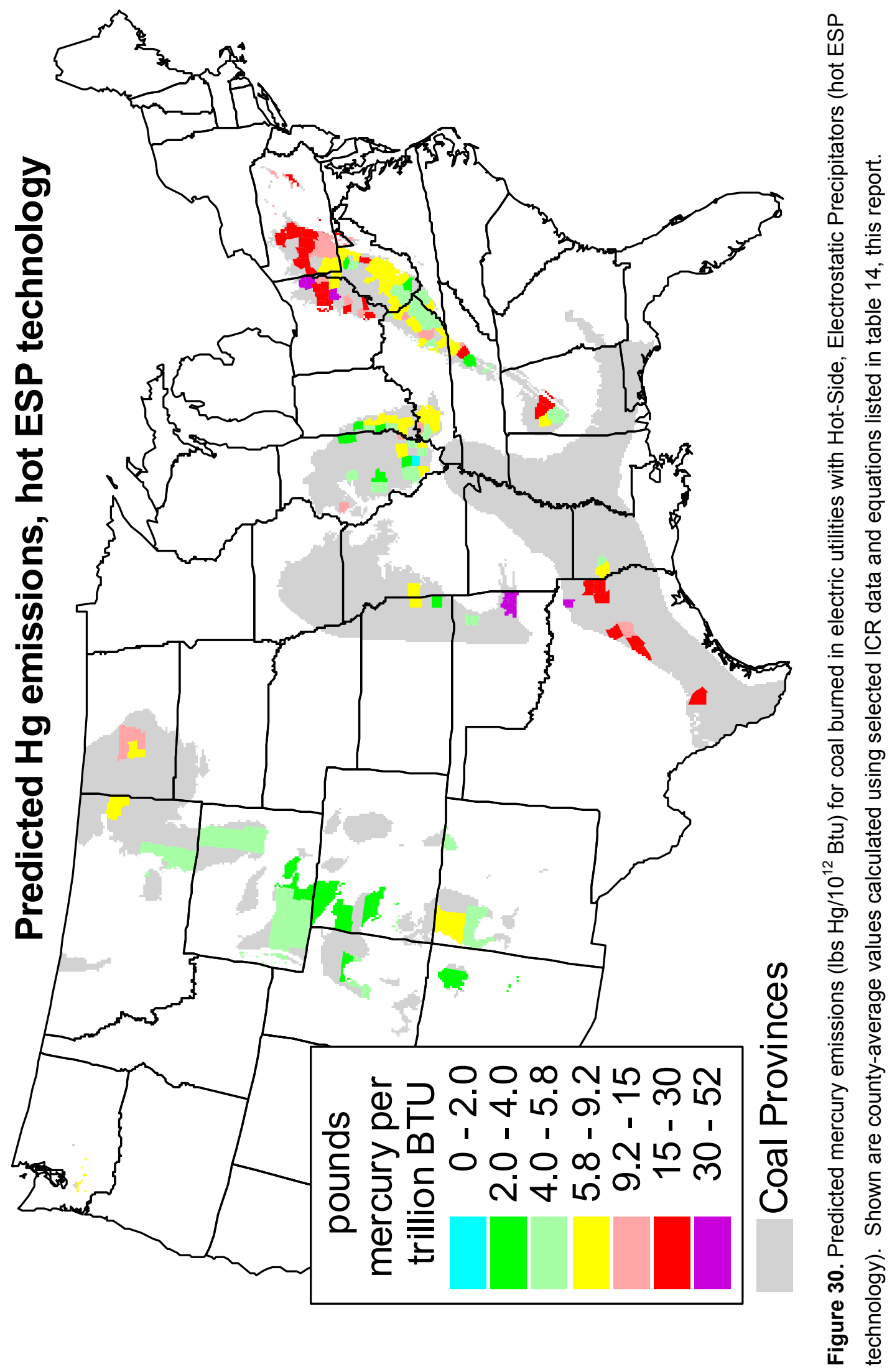




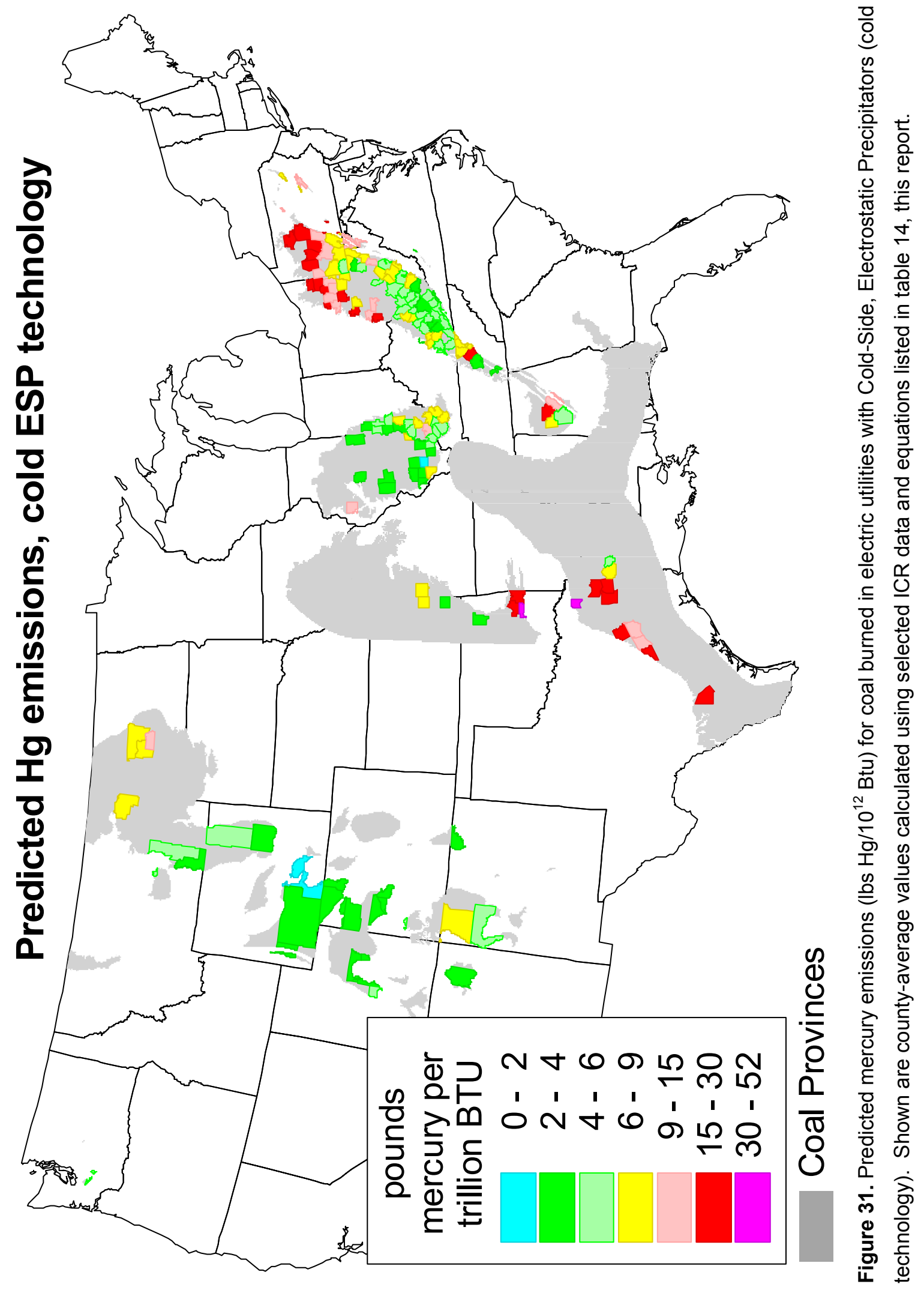




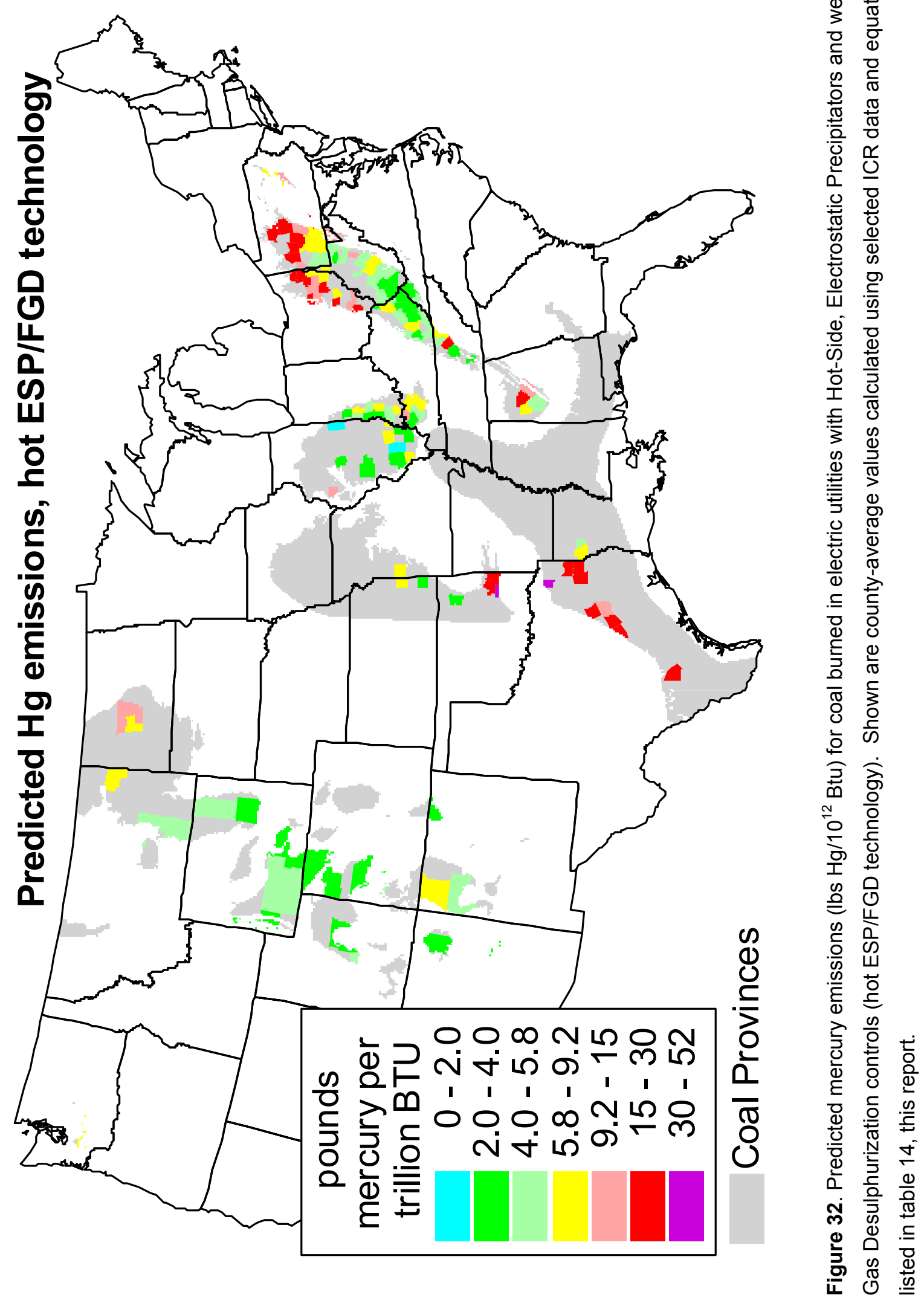




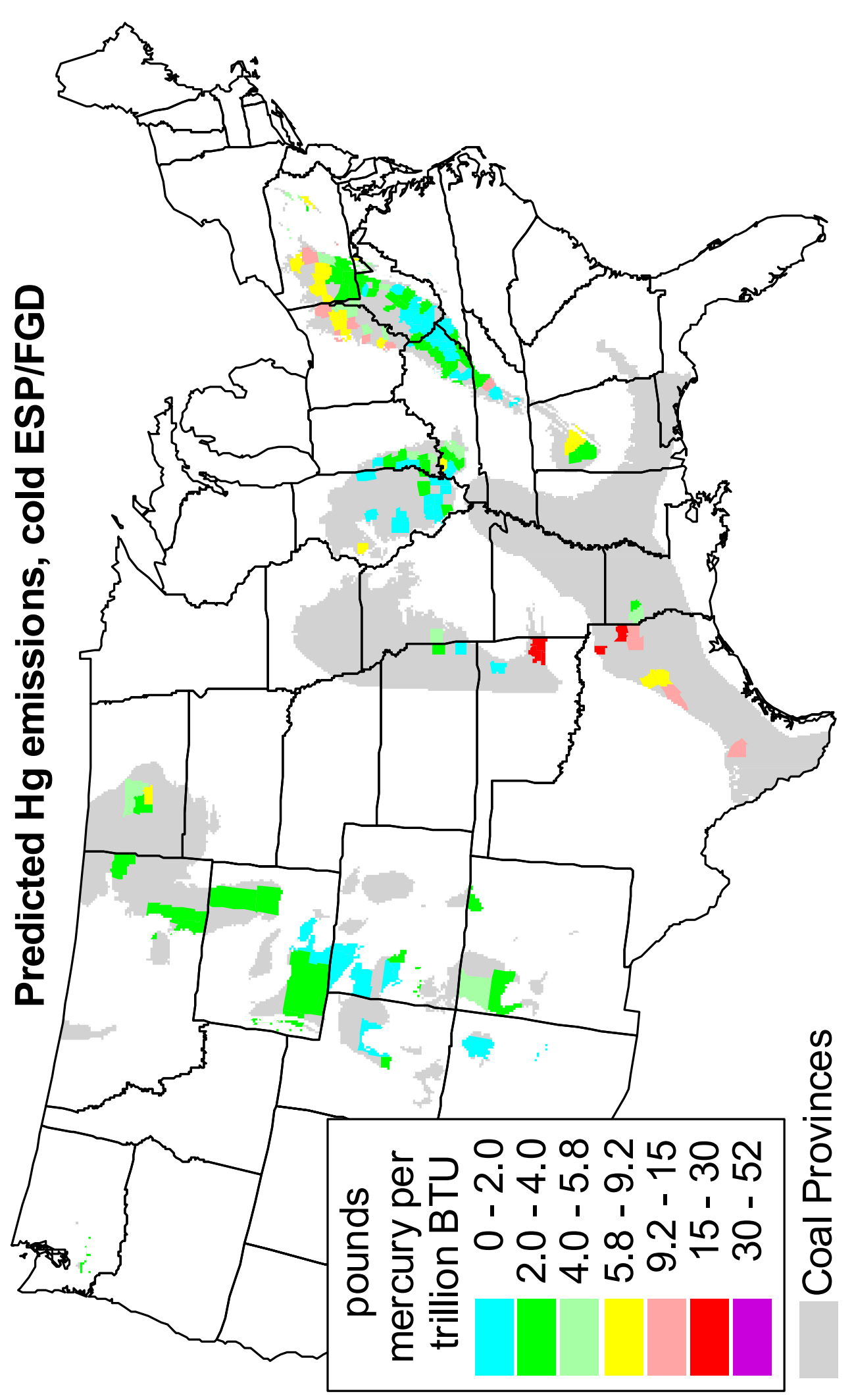

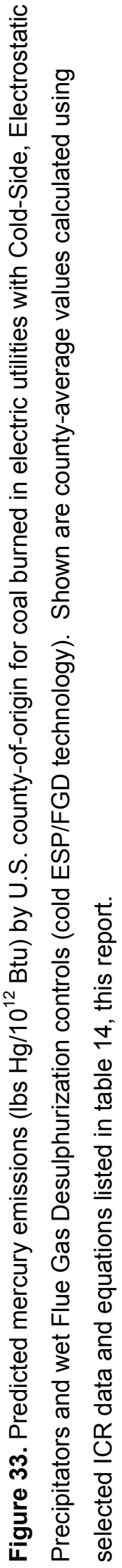




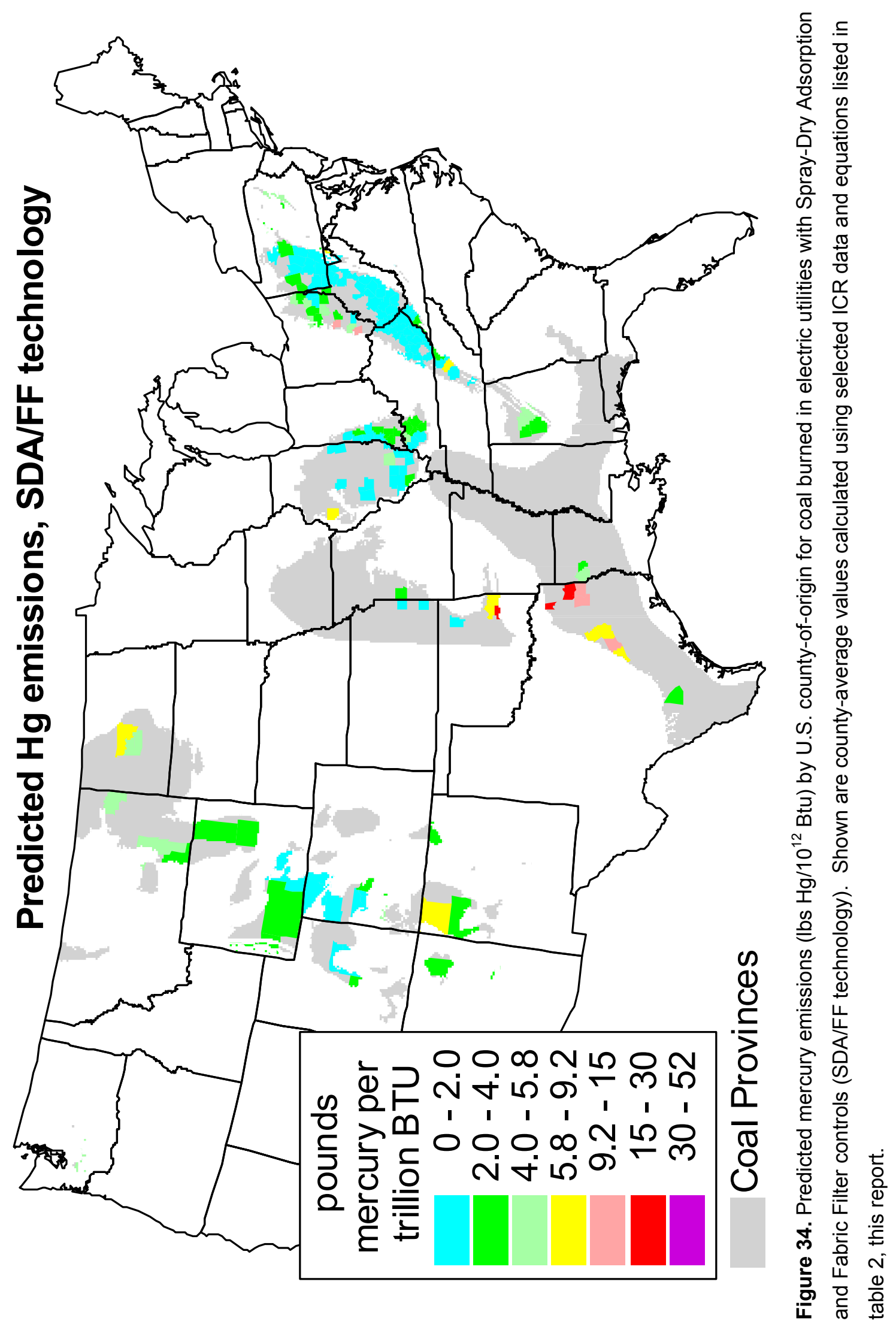




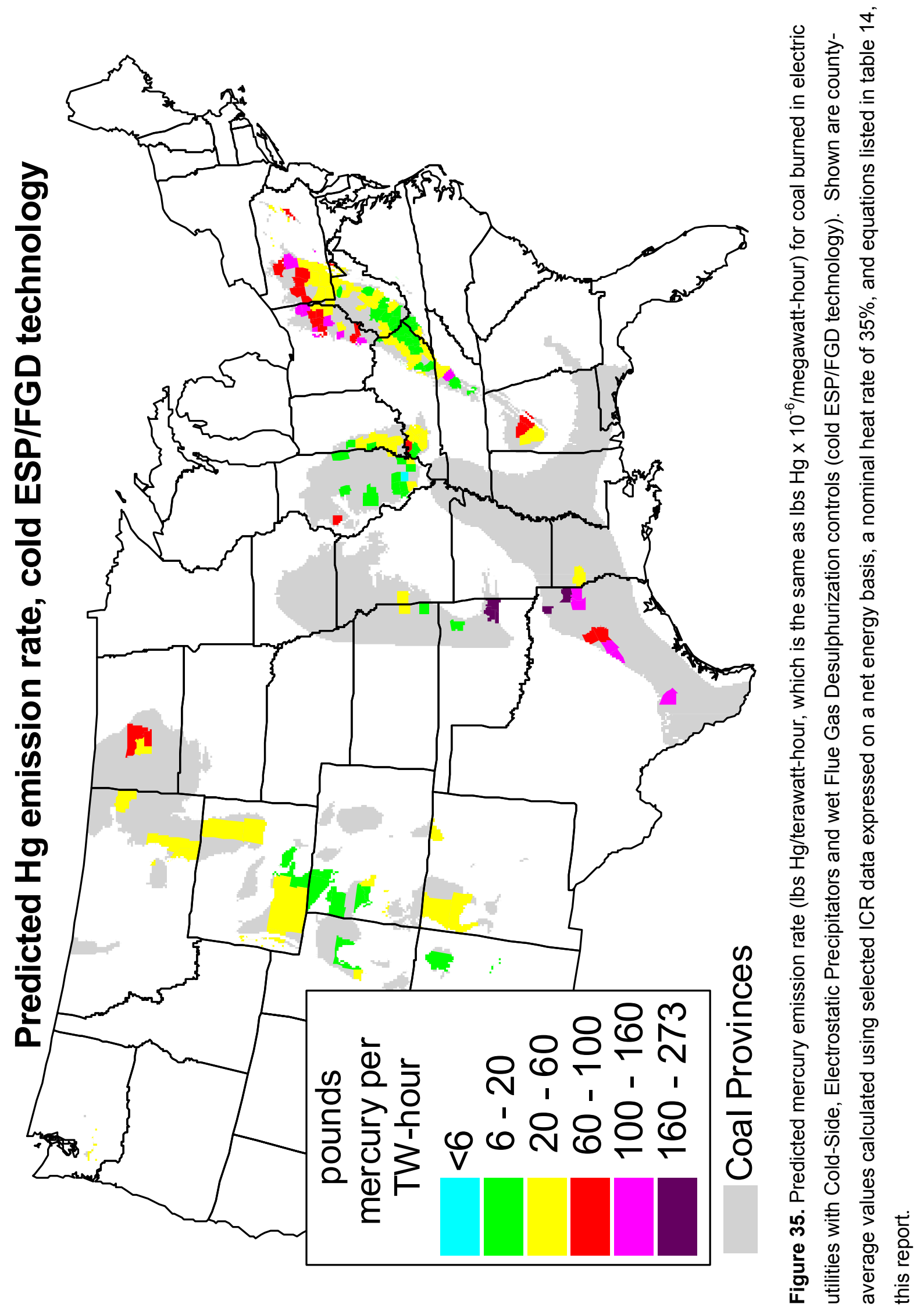




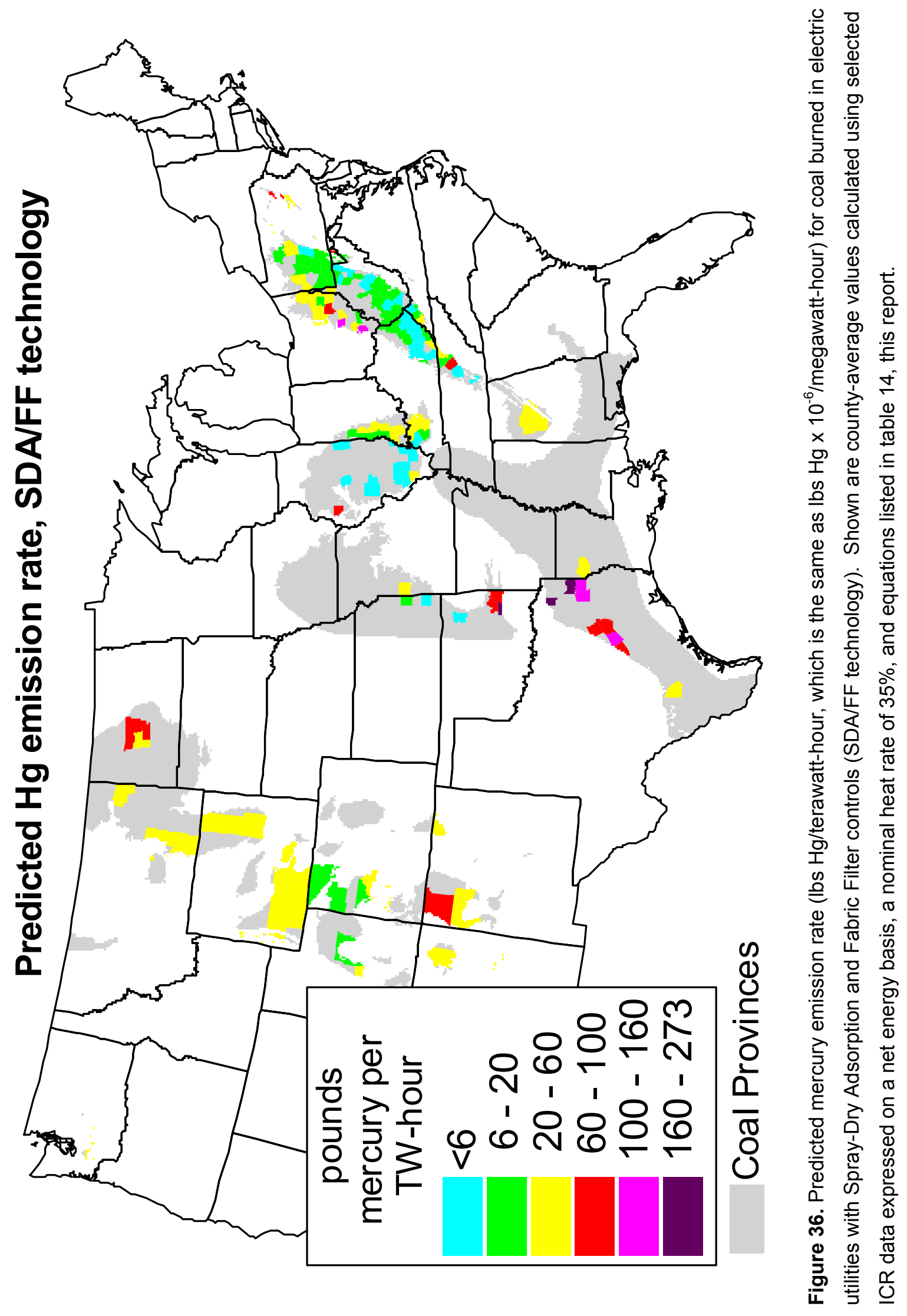




\section{Selecting the Best Equation to Predict Mercury Capture}

Table 14 lists three equations that predict mercury capture for each of five different existing control technologies. As previously discussed, the equations were all derived by regression analysis on the ICR 3 stack emission data (USEPA, 2003), and use various measures of coal quality (chlorine, Btu/lb, and sulfur values) as independent variables. Although the technology-specific equations show similar correlations and trends (figures 21, 22, 23, 24, and 25), results sometimes differ when they are applied to the same county-average coal quality values. Lacking objective criteria to select a single best equation from those listed in table 14, we used the average result obtained from all three equations.

Clearly, our decision to use all three equations, rather than just one, could be considered arbitrary. However, using three equations should reduce extrapolation error when an equation is applied to assay values that are outside the range of ICR part 3 values that these regression equations were made from. For example, figure 25 shows that the different equations predict substantially different results for high-chlorine coal burned in units with hESP technology. With one exception (Cliffside unit 1), relatively low-chlorine coal was burned in ICR part 3 units equipped with this technology. Consequently, the validity of the hESP-specific equations is uncertain for high-chlorine coal. Nonetheless, given the divergent results for high-chlorine coal shown in figure 25 , using the average result from all three equations clearly avoids large errors necessarily associated with at least one of the equations.

Admittedly, there are other useful and significant equations that are not included in table 14 (Chu and others, 2000; Laumb and others, 2000; AEMS, 2004). However, the selection of equations for table 14 was not wholly arbitrary. The selection was instead a compromise that

required similar technology classes, and favored high $\mathrm{r}^{2}$ values, diverse authorship, and different 
independent variables. Selecting three (rather than two, four, or more) equations for each technology group was likewise a compromise. This convention simplified spreadsheet calculations and allowed for the inclusion of convex, concave, and linear equation forms.

\section{Comparison of Existing Technologies: Implications for Mercury Control}

Figure 26 compares the average technology-specific mercury capture calculated for 162 U.S. counties using the average result from the three equations listed in table 14 for each technology control class. Note that mercury capture increases as coal chlorine increases for each control technology. This trend is particularly noteworthy for $\mathrm{SDA} / \mathrm{FF}$ and cESP/FGD technologies, where capture rapidly increases up to about $500 \mathrm{ppm}$ chlorine, but only modestly increases above 1000 ppm chlorine. Thus, blending a low-chlorine coal with a high-chlorine coal to an optimum level between 500 and $1000 \mathrm{ppm}$ chlorine, should result mercury capture for coal burned in units equipped with SDA/FF or cESP/FGD emission controls. Of course, mercury emissions will also depend on the total mercury content of the blended coal feedstock.

Units equipped with $\mathrm{hESP} / \mathrm{FGD}$, cESP, or hESP emission controls show relatively poor mercury capture. Absent effective mercury-specific controls, selection of lower mercury coal would be a good mercury reduction strategy for these units.

Weighting the county-specific results shown in figure 26 by county production tonnage allows calculation of the average mercury emissions, together with the average percent reduction, for each post-combustion technology. Likewise, the effectiveness of pre-combustion technology can be calculated by comparing in-ground coal mercury with commercially shipped coal mercury and weighting the results by county production. Table 15 shows the results of these calculations. 
Table 15. Comparison of mercury control technologies.

\begin{tabular}{|c|c|c|c|c|}
\hline & Technology & $\underline{\text { Trillion Btu }}^{1}$ & $\underline{\mathrm{lbs} \mathrm{Hg} / 10^{12} \mathrm{Btu}}$ & $\begin{array}{l}\% \text { Mercury } \\
\text { Reduction }\end{array}$ \\
\hline \multirow{4}{*}{$\begin{array}{l}\text { Pre- } \\
\text { Combustion }\end{array}$} & $\begin{array}{l}\text { None (In-ground coal, } \\
\text { COALQUAL data) }\end{array}$ & - & $\sim 11.0$ & - \\
\hline & $\begin{array}{l}\text { Counties with no mercury } \\
\text { reduction (ICR data) }\end{array}$ & 5,931 & 11.2 & - \\
\hline & 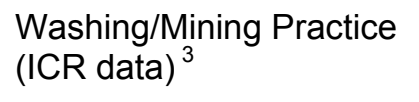 & 11,335 & 6.3 & $\sim 57 \%$ \\
\hline & $\begin{array}{l}\text { No data (counties without } \\
\text { COALQUAL or ICR data) }\end{array}$ & 1,809 & $?$ & $?$ \\
\hline \multirow{6}{*}{$\begin{array}{l}\text { Post- } \\
\text { Combustion }\end{array}$} & None (delivered coal) & 19,047 & 8.3 & - \\
\hline & hESP & 1,769 & 7.5 & $9 \%$ \\
\hline & cESP & 10,260 & 6.4 & $23 \%$ \\
\hline & hESP/FGD & 565 & 6.2 & $25 \%$ \\
\hline & cESP/FGD & 3,579 & 3.4 & $59 \%$ \\
\hline & SDA/FF & 511 & 3.1 & $63 \%$ \\
\hline \multicolumn{5}{|c|}{$\begin{array}{l}\text { Amount of coal, expressed as coal Btu content; post-combustion values from Chu and others } \\
(2000) \text {. } \\
2 \text { The } 11 \mathrm{lb} \mathrm{Hg} / 10^{12} \text { Btu value for the total U.S. in-ground coal resource was calculated using state- } \\
\text { average COALQUAL Hg values, and weighting by estimated coal resource (tonnage) values from the } \\
\text { USEIA (2005) } 1997 \text { vintage, demonstrated reserve base. This value (and the derived } 57 \% \text { mercury } \\
\text { reduction due to washing and mining practice) will likely change when the demonstrated reserve base } \\
\text { estimate is updated. }\end{array}$} \\
\hline \multicolumn{5}{|c|}{$\begin{array}{l}{ }^{3} \text { Counties where the mercury content of the in-ground coal is more than } 2 \mathrm{lbs} \mathrm{Hg} / 10^{12} \text { Btu greater } \\
\text { than the mercury content of commercial coal shipped from that county. }\end{array}$} \\
\hline
\end{tabular}

Several caveats apply to table 15 . First, mercury reductions listed for cESP/FGD and SDA/FF technologies are likely minimum values because they indicate the fractional emissions expected if all U.S. coal were burned in these technology classes, rather than the coals that are currently burned. Many of these units burn coal blends originating from several counties. As noted above, the optimal mercury capture for these technologies occurs where the coal contains between 500 and $1000 \mathrm{ppm}$ chlorine. Given that the tonnage-weighted average chlorine content of U.S. coal is $\sim 530 \mathrm{ppm}$, coal blends are more likely to approach this optimal value than singlesourced coal. 
Table 15 shows that in-ground U.S. coal contains about $11 \mathrm{lbs} \mathrm{Hg} / 10^{12} \mathrm{Btu}$. This value is less certain than the mercury content of coal delivered to power plants during 1999 included in the ICR data set. For example, weighting COALQUAL mercury values aggregated by U.S. state (excluding Alaska), by the USEIA (2005) Demonstrated Reserve Base tonnage estimates for these states shows an average $10.8 \mathrm{lbs} \mathrm{Hg} / 10^{12} \mathrm{Btu}$. However, where average COALQUAL mercury values for counties listed in the ICR data set are weighted by coal production tonnage, the result is $11 \mathrm{lbs} \mathrm{Hg} / 10^{12} \mathrm{Btu}$.

Another limitation of values listed in table 15 relates to the likely co-reduction of coal sulfur due to coal mining and coal washing practice. As noted below, coal sulfur decreases postcombustion mercury capture. Consequently, the technology-specific, post-combustion mercury reductions listed in table 15 may increase if the sulfur content of commercial U.S. coal continues to decline (Quick and others, 2003).

\section{The Relationship Between Coal Sulfur and Mercury Capture}

Figure 26 shows that mercury emissions from SDA/FF controls are exclusively correlated with chlorine whereas mercury emissions predicted for the other technologies are more variable. The scatter shown in figure 26 for cESP/FGD, hESP/FGD, cESP, and hESP technologies is attributed to coal sulfur, which is a factor in one or more of the respective equations for these technologies (table 14), but not used in the SDA/FF equations. Notably, in every equation where sulfur is an independent variable (table 14), mercury capture is predicted to decline with increasing coal sulfur.

The equations listed in table 14 clearly show the consistently negative effect of coal sulfur on mercury capture. The explanation for this effect is less obvious. Hocquel and others (2001) offered two explanations for the negative effect of sulfur on mercury capture; both reduce 
the amount of $\mathrm{Cl}_{2}$ available for mercury oxidation. The first inhibits the heterogeneous conversion of $\mathrm{HCl}$ to reactive $\mathrm{Cl}_{2}$ by sulfation of metal oxides that would otherwise catalyze this conversion. The second indicates that gaseous $\mathrm{SO}_{2}$ in the presence of water vapor can homogenously reduce $\mathrm{Cl}_{2}$ to less-reactive $\mathrm{HCl}$ and by-product $\mathrm{SO}_{3}$. A mechanistic model for mercury capture by fly-ash carbon (Olson and others 2003) suggests that sulfuric acid (from oxidation of flue-gas $\mathrm{SO}_{2}$ ) limits mercury capture by filling $\mathrm{Hg}$ binding/reaction sites on the carbon surface.

Alternately, the negative effect of coal sulfur on mercury capture may simply relate to higher flue-gas temperatures required to avoid corrosion of the ductwork from $\mathrm{H}_{2} \mathrm{SO}_{4}$ when burning high-sulfur coal. Meij and others (2002) attributed the greater mercury capture by ESP controls on power plants in the Netherlands, compared to those in Germany and the U.S., to lower flue-gas ESP temperatures in the Netherlands power plants $\left(\sim 120^{\circ} \mathrm{C}\right)$, which burn comparatively low-sulfur coal. The median temperature for cold-side ESP units included in the ICR part 3 data set of U.S. power plants is about $160^{\circ} \mathrm{C}$, whereas Meij and others (2002) suggested that oxidized mercury, present as $\mathrm{HgCl}_{2}$, does not condense on fly ash above about $140^{\circ} \mathrm{C}$.

Empirical data from Canadian Electricity Association members (CEA, 2004) also show a negative correlation between coal sulfur on mercury capture. The relationship (figure 37) is strongest where fly-ash carbon exceeds five percent (and chlorine is coincidentally high). This relationship is consistent with the mechanistic model suggested by Olson and others (2003) where sulfur fills reactive sites on fly-ash carbon. Their explanation may also explain why sulfur is not a significant predictor of mercury capture for units equipped with SDA/FF technology; in this instance, gaseous flue-gas sulfur is converted to a non-reactive solid (sulfate) before it 
arrives at the particulate filter, where effective mercury capture by fly-ash carbon presumably occurs.

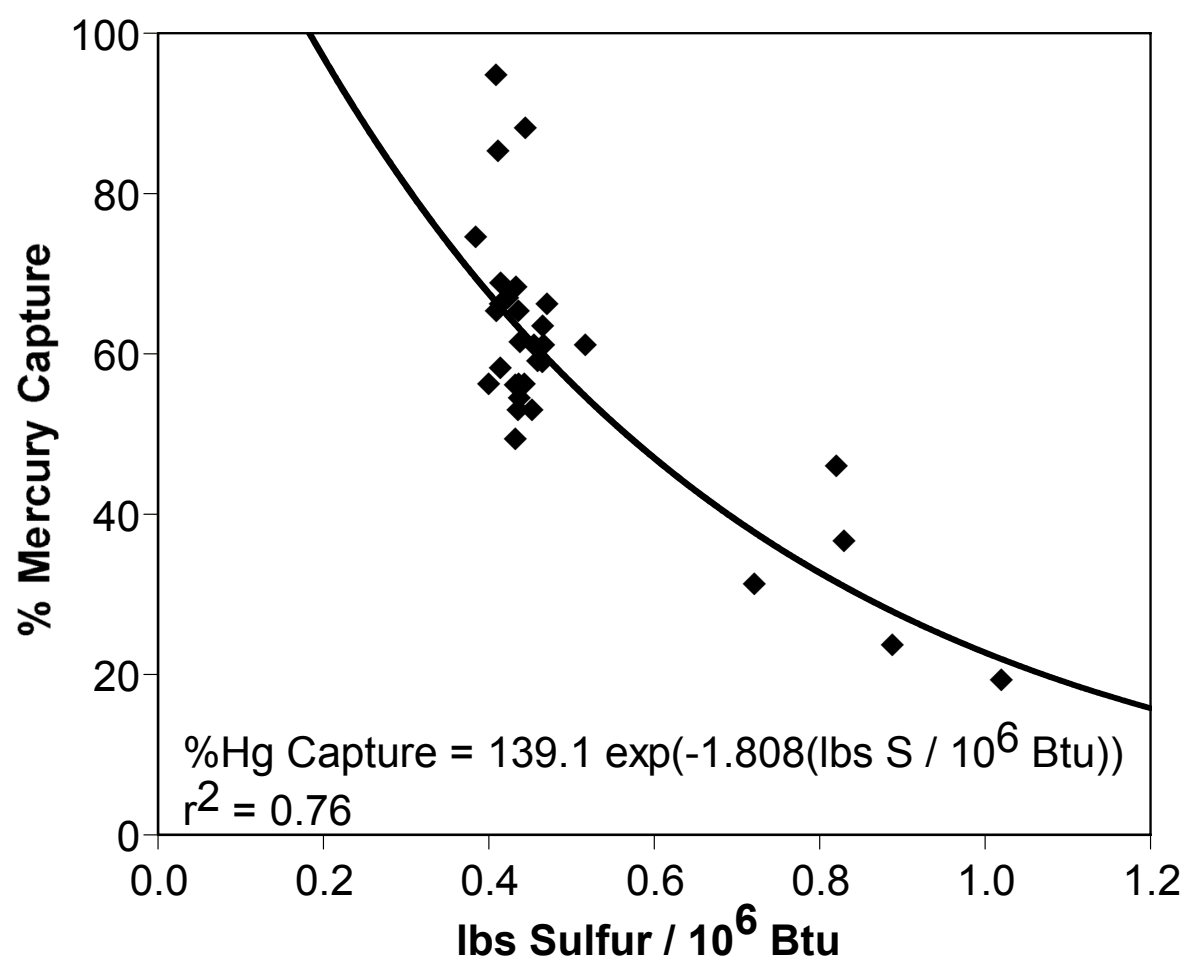

Figure 37. Decreasing mercury capture with increasing coal sulfur. Data points show weekly averages (CEA, 2004) observed for two units equipped with cESP emission controls where fly-ash carbon exceeds 5\% (average 11\%). Mercury capture was estimated after Meij and others (2002) using coal and fly-ash mercury values, and assuming an 80:20, fly ash:bottom ash fractionation. Two data points greater than $100 \%$ capture are not shown.

In this section we have suggested that mercury capture by carbon in fly ash may be improved by reducing the amount of sulfur in the feed coal. This effect complements the likely reduction of mercury in the coal when the sulfur content of coal is reduced (Quick and others, 2003). Thus, selection of low-sulfur coal has two likely effects: (1) reducing the amount of mercury in the feed coal, and (2) improving post-combustion mercury capture. 


\section{In-Ground Coal Mercury Compared to Commercial Coal Mercury}

Direct comparison of COALQUAL data records (in-ground coal) with ICR data records (commercial coal) showed that coal delivered to utilities during 1999 has about half as much mercury as the in-ground coal resource (Quick and others, 2003). This difference was attributed to preferential mining of relatively low-mercury coal, and coal washing. Toole-O'Neil and others (1999) noted that washing reduces coal mercury levels by about 35\%. Restricting the comparison to counties where both COALQUAL and ICR data are available, and weighting the county-average mercury values by coal production tonnage, shows that the in-ground coal resource averages about $11 \mathrm{lbs} \mathrm{Hg} / 10^{12} \mathrm{Btu}$, whereas commercial coal deliveries during 1999 averaged about $8.3 \mathrm{lbs} \mathrm{Hg} / 10^{12} \mathrm{Btu}$. Perhaps more significantly, this difference is not geographically uniform. For example, figure 19 shows that coal produced from the northern Appalachians and Gulf Coast regions typically has more mercury than expected from the mercury content of the in-ground coal. The reason for these increased mercury levels is uncertain. Possibly, the increased mercury levels result from dilution of mined coal with either surrounding, high-mercury country rock or included, high-mercury rock partings. If so, coal washing or selective mining might be effective mercury reduction strategies in these areas.

Areas where mined coal contains more mercury than the in-ground coal may be good places to consider pre-combustion mercury reduction strategies. Comparing the mercury content of mined coal with the mercury content of in-ground coal has more immediate significance because it shows the significance of pre-combustion mercury reduction strategies (selective mining and coal washing). Indeed, the mercury content of U.S. coal delivered to the power plant during 1999 contained, on average, $2.8 \mathrm{lbs} \mathrm{Hg} / 10^{12}$ Btu less mercury than the in-ground coal resource. This $25 \%$ mercury reduction is significant. 


\section{CONCLUSIONS}

- Selection of coal with low mercury content may be an effective control strategy for units equipped with hESP/FGD, cESP, or hESP controls, whereas selection of highchlorine coal is indicated for units with cESP/FGD or SDA/FF controls.

- $\quad$ Blending to an optimum level between 500 and 1000 ppm chlorine may be an effective mercury control strategy for units equipped with SDA/FF or cESP/FGD controls.

- $\quad$ Flue-gas sulfur may reduce mercury capture by carbon in fly ash.

- Coal washing or selective mining might be an effective mercury reduction strategy, especially for coals from the northern Appalachians or Gulf Coast. 


\section{REFERENCES}

AEMS, LLC, 2004, Review and critique of data and methodologies used in the USEPA proposed utility mercury MACT rulemaking, report prepared for the National Mining Association: AEMS, LLC, Arlington Virginia, and RW Crawford Energy, Tuscon Arizona, 88 p., Online, $<$ nma.org/pdf/pol_briefs/mact_critique_072004.pdf>, accessed July 2004.

anonymous, 1990, The Penn State Coal Sample Bank and Data Base, second edition: Coal and Organic Petrology Laboratories, University Park, Pennsylvania, The Pennsylvania State University, unpaginated data sheets.

American Society for Testing and Materials, 1990, D 388-90 Standard classification of coals by rank, Annual Book of ASTM Standards: West Conshohocken, Pennsylvania, v. 05.05, p. 193-197.

- 2000a, D 3180-89 Standard practice for calculating coal and coke analyses from asdetermined to different bases, Annual Book of ASTM Standards: West Conshohocken, Pennsylvania, v. 05.06, p. 252-255.

— 2000b, D 5373-93 Standard test methods for instrumental determination of carbon, hydrogen, and nitrogen in laboratory samples of coal and coke, Annual Book of ASTM Standards: West Conshohocken, Pennsylvania, v. 05.06, p. 453-456.

Belyaev, S.S., Yy-Lein, A., and Ivanov, M.V., 1980, Role of methane-producing and sulfatereducing bacteria in the destruction of organic matter, in Trudinger, P.A., and Walter, M.R., editors, Biogeochemistry of ancient and modern environments: Proceedings of the Fourth International Symposium on Environmental Biogeochemistry (ISEB) and Conference on Biogeochemistry in Relation to the Mining Industry and Environmental Pollution (Leaching Conference), 26 August to 4 September, 1979, Canberra, Australia: Australian Academy of Science, p. 235-242.

Bowling, C.M., [1996?] Determination of net calorific value at constant pressure from gross calorific value measured at constant volume in a bomb calorimeter on coal: ASTM Research Report D-05-1013, 3 p. 
Bragg, L.J., Oman, J.K., Tewalt, S.J., Oman, C.L., Rega, N.H., Washington, P.M., and Finkelman R.B., 1997, Coal quality (COALQUAL) database - version 2.0: U.S. Geological Survey Open-File Report 97-134, CD-ROM.

Canadian Electricity Association, 2004, Mercury program, sampling and analysis, participant data (preliminary): Online, <ceamercuryprogram.ca/EN/sampling_data.html>, accessed October 2004.

Chu, P., Goodman, N., Behrens, G., and Roberson, R., 2000, Total and speciated mercury emissions from coal-fired power plants: Palo Alto, California, Electric Power Research Institute, 15 p., Online, <epri.com/attachments/262300_EUEC_pchu_1-01.pdf>, accessed July 2004.

Cole, J., 2003, MACT floor unit conversion from input-based standard to output-based standard in the proposed national emission standards for hazardous air pollutants; and, in the alternative, proposed standards of performance for new and existing stationary sources electric utility steam generating units, memorandum to Bill Maxwell, U.S. USEPA OAQPS (C439-01): RTI International, 2 p., Online, <epa.gov/ttn/atw/utility/mact_unit_conv_011504.pdf> accessed July 2004.

Davis, A., and Glick, D.C., 1993, Establishment and maintenance of a coal sample bank and data base, final report to the U.S. Department of Energy for contract DE-RP22-87PC79997: University Park, The Pennsylvania State University, Coal and Organic Petrology Laboratories, $266 \mathrm{p}$.

Electric Power Research Institute, 2000, An Assessment of Mercury Emissions from U.S. CoalFired Power Plants: EPRI, Palo Alto, CA, TR-1000608

ENSR Corporation, 2003, Multivariable method to estimate the mercury emissions of the bestperforming coal-fired utility units under the most adverse circumstances which can reasonably be expected to recur; report DC $\backslash 566987.6$ prepared for WEST Asscociates, Tucson, Arizona, and present at the March 4, 2003 meeting of the Clean Air Act Advisory Committee Permits/New Source Review/Air Toxics Subcommittee Utility MACT Working Group: 45 p., Online, <epa.gov/ttn/atw/combust/utiltox/final_ensr_multivar.pdf>, accessed July 2004. 
Eutizi, J.G., 2005, Comment from San Miguel Electric Cooperative to EPA Docket OAR-20020056, in response to the Notice Of Data Availability for the proposed clean air mercury rule, 69 FR 69864, Dec. 1, 2004: Online, <docket.epa.gov/edkpub/index.jsp>, Accessed January 2005, OAR-2002-0056-3463, 3 p.

Given, P.H., Weldon, D., and Zoeller, J.H., 1986, Calculation of calorific values of coals from ultimate analyses - theoretical basis and geochemical implications: Fuel, v. 65, p. 849854.

Glacken, S., 2005, Comment from TXU Power to EPA Docket OAR-2002-0056, in response to the Notice Of Data Availability for the proposed clean air mercury rule, 69 FR 69864, Dec. 1, 2004: Online, <docket.epa.gov/edkpub/index.jsp>, Accessed January 2005, OAR-2002-0056-5490, 2p.

Gorbaty, M.L., and Kelemen, S.R., 2001, Characterization and reactivity of organically bound sulfur and nitrogen in fossil fuels: Fuel Processing Technology, v. 71, p. 71-78.

Hocquel, M., Unterberger, S., and Hein, K.R.G., 2001, Influence of $\mathrm{HCl}, \mathrm{SO}_{2}, \mathrm{CaO}$ and catalytic material on the speciation of mercury: Proceedings of the Air and Waste Management Association Specialty Conference on Mercury Emissions, Fate, Effects, and Control, August 21-23, Chicago, Illinois, $11 \mathrm{p}$.

Houghton, J.T., Meira Filho, L.G., Lim, B., Tréanton, K., Mamaty, I., Bonduki, Y., Griggs, D.J., and Callander, B.A., 1997, Greenhouse Gas Inventory Reference Manual, Revised 1996 IPCC Guidelines For National Greenhouse Gas Emissions (chapter 1, volume 3): Geneva, Switzerland, World Meteorological Organization, Intergovernmental Panel on Climate Change, $145 \mathrm{p}$.

Juniper, L., 1998, Competitiveness of Queensland thermal coals in the export market, UltraSystems Technology Pty Ltd Report C1044 for the Queensland Department of Mines and Energy: Brisbane, Australia, 57 p.

Laumb, J., Jensen, R., and Benson, S., 2000, Information Collection Request (ICR) for mercury - correlation analysis of coal and power plant data: Proceedings of the Air Quality II Mercury, Trace Elements, and Particulate Matter Conference, McLean Virginia, Sept. 1921, poster paper 15. 
Luppens, J.A., Hoeft, A.P., 1991, Relationship between inherent and equilibrium moisture contents in coals by rank: Journal of Coal Quality, v. 10, no. 4, p.133-141.

Maes, I.I., Gryglewicz, G., Machnikowska, H., Yperman, Y., Franco, D.V., Mullens, J., and Van Pouke, L.C., 1997, Rank dependence of organic sulfur functionalities in coal: Fuel, v. 76, p. 391-396.

McCall, M., 2004, Comment from TXU Power to EPA Docket OAR-2002-0056, in response to the proposed mercury rule 69 FR 4652, Jan. 30, 2004: Online, $<$ docket.epa.gov/edkpub/index.jsp>, Accessed January 2005, OAR-2002-0056-3478, 37 p.

McCutcheon, A.L., and Barton, W.A., 1999, Contribution of mineral matter to water associated with bituminous coals: Energy and Fuels, v.13, p. 160-165.

Meij, R., Vredenbregt, L.H.J., and Winkel, H., 2002, The fate and behavior of mercury in coalfired power plants: Journal of the Air and Waste Management Association, v. 52, p. 912917.

Mott, R.A., and Spooner, C. E., 1940, The calorific value of carbon in coal - the Dulong relationship: Fuel, v. 19, p. 242-231 and 242-251.

Neavel, R.C., Smith, S.E., Hippo, E.J., and Miller, R.N., 1986, Interrelationships between coal compositional parameters: Fuel, v. 65, p. 312-320.

Neavel, R.C., 1990, Excess moisture and excess taxes: paper presented at the $8^{\text {th }}$ International Coal Testing Conference, September 17-20, Lexington Kentucky, 13 p.

Nyberg, C., 2003, Quantitative determination of chlorine in lignite and subbituminous coals, Center for Air Toxic Metals Newsletter: Grand Forks, University of North Dakota, Energy and Environmental Research Center, v. 9, issue 2, p. 6 and 8.

Olson, E.S., Laumb, J.D., Benson, S.A., Dunham, G.E., Sharma, R.K., Mibeck, B.A., Crocker, C.R., Miller, S.J., Holmes, M.J., and Pavlish, J.H., 2003, The mechanistic model for flue gas-mercury interactions on activated carbons: Proceeding of the Air Quality IV Mercury Trace Elements and Particulate Matter Conference, September 22-24, Arlington Virginia, 9 p. 
Quick, J.C., Brill, T.C., and Tabet, D.E., 2003, Mercury in US coal - observations using the COALQUAL and ICR data: Environmental Geology, v. 43, p. 247-259.

Quick, J.C., and Glick, D.C., 2000, Carbon dioxide from coal combustion - variation with rank of US coal: Fuel, v. 79, p. 803-812.

Roberson, R., 2002, UARG variability analysis, memorandum to Bob Wayland, U.S. Environmental Protection Agency, presented at the October 17, 2002 meeting of the Clean Air Act Advisory Committee Permits/New Source Review/Air Toxics Subcommittee Utility MACT Working Group: Raleigh, North Carolina, RMB Consulting and Research, 4 p., Online, <epa.gov/ttn/atw/combust/utiltox/epavarifnl.doc>, accessed July 2004.

Robinson, J.M., 1990, Lignin, land plants and fungi - Biological evolution affecting Phanerozoic oxygen balance: Geology, v. 15, p. 607-610.

Sarunac, N., Levy, E.K., Bullinger, C., and Ness, M., 2005, Impact of coal drying on power plant efficiency, operations and emissions: Presentation at the 2005 Clearwater Conference, 40 slides.

Scaroni, A.W., Davis, A., Glick, D.C., Hatcher, P.G., Mitchell, G.D., Carson, D., and Lei, H., 1999, Maintenance of the coal sample bank and data base; final technical report for the U.S. Department of Energy contract DE-AC22-93PC93051: University Park, The Pennsylvania State University, Coal and Organic Petrology Laboratories, 192 p.

Science Applications International Corporation, 2003, Calculation of possible mercury MACT floor values for coal-fired utilities - influence of variability and approach; report for the U.S. Department of Energy: Reston, Virginia, SAIC Corp., 46 p., 8 appendices, Online, $<$ netl.doe.gov/coal/E\&WR/mercury/pubs/DOE_Report_v120803.pdf >, accessed August 2004.

Sinninghe Damste, J.S., Rijpstra, W.I.C., Kock-Van Dalen, A.C., deLeeuw, J.W., and Schenk, P.A., 1989, Quenching of labile functionalized lipids by inorganic sulfur species evidence for the formation of sedimentary organic sulfur compounds at the early stage of diagenesis: Geochimica et Cosmochimica Acta, v. 53, p. 143-155. 
Stultz, S.C., and Kitto, J.B., (eds) 1992. Steam, its Generation and Use $-40^{\text {th }}$ edition: Barberton Ohio, Babcock and Wilcox Co, 982p

Swanson, V.E., and Huffman, C. Jr., 1976, Guidelines for sample collecting and analytical methods used in the U.S. Geological Survey for determining chemical composition of coal: U.S. Geological Survey Circular 735, 11 p.

Toole-O'Neil, B., Tewalt, S.J., Finkelman, R.B., and Akers, D.J., 1999, Mercury in coal unraveling the puzzle: Fuel, v.78, p.47-54.

Trumbell, J.V.A., 1960, Coal fields of the United States, exclusive of Alaska - sheet 1: U.S. Geological Survey Map, scale 1:5,000,000, Online, <nationalatlas.gov/coalfdm.html>, accessed February 2004.

U.S. Energy Information Administration, 2000, Coal Industry Annual 2000 (see table 33): DOE/EIA-0584, Online, <eia.doe.gov/FTPROOT/coal/05842000.pdf), accessed January $2005,311 \mathrm{p}$.

- 2003a, FERC Form 423 Database, Monthly cost and quality of fuels for electric power plants: Online, <eia.doe.gov/cneaf/electricity/page/ferc423.html>, accessed October and November 2003.

- 2003b, The Coal Transportation Rate Database data tables: Online, <eia.doe.gov/cneaf/coal/ctrdb/database.html>, accessed October and November 2003.

- 2003c, Table 4.1. Consumption of Fossil Fuels for Electricity Generation by Type of Power Producer, 1990 through 2001: Electric Power Annual 2001 Data Tables, U.S. Energy Information Administration, Online, <eia.doe.gov/cneaf/electricity/epa/epa_sum.html>, accessed October and November 2003.

— 2005, The Coal Reserves Database (CRDB) for 1997: U.S. Energy Information Administration, Online, < http://www.eia.doe.gov/cneaf/coal/reserves/database.html>, accessed August 2005.

U.S. Environmental Protection Agency, 2003, Unified air toxics website, electric utility steam generating units hazardous air pollutant emission study: Online, <epa.gov/ttn/atw/combust/utiltox/utoxpg.html>, accessed October and November 2003. 
- 2005, Standards of Performance for New and Existing Stationary Sources - Electric Utility

Steam Generating Units: U.S. Federal Register, Volume 70, Number 95, pp. $28605-$ 28700, Online, <epa.gov/ttn/atw/utility/utiltoxpg.html>, accessed March 2005.

U.S. Mine Safety and Health Administration, 2004, Accident, Illness and Injury and Employment Self-Extracting Files (PART 50 DATA) Master Index File: Online, $<$ http://www.msha.gov/STATS/PART50/P50Y2K/Y2KMIF.HTM>, accessed November 2004. 


\section{Appendix A}

\section{Calculation and significance of the Mott-Spooner value}

The Mott-Spooner value is the heating value $(\mathrm{Btu} / \mathrm{lb})$ calculated from the elemental composition of the coal. The difference between the calculated and the measured Btu/lb value $\left(\mathrm{Btu} / \mathrm{l} \mathrm{b}_{\text {measured }}-\mathrm{Btu} / \mathrm{lb}_{\text {calculated }}\right)$ is called the Mott-Spooner difference, and is useful to identify erroneous data (sources of error include data entry mistakes, assay errors, or inconsistent reporting bases). We calculated Mott-Spooner difference values to evaluate the suitability of the COALQUAL data for estimation of coal hydrogen values. Coal hydrogen values are required to calculate net specific energy values.

Although numerous equations can be used to calculate the heating value from elemental composition (Neavel and others, 1986) we use equations listed by Mott and Spooner (1940). For higher rank coals with less than $15 \%$ oxygen, the coal heating value is calculated as:

$$
B t u / I b_{d a f}=144.5 H_{d a f}+40.5 S_{d a f}-62.5 O_{d a f} .
$$

For lower rank coals with more than $15 \%$ oxygen, the equation is:

$$
B t u / l b_{d a f}=144.5 C_{d a f}+610.2 H_{d a f}+40.5 S_{d a f}-65.9 O_{d a f}+0.310\left(O_{d a f}\right)^{2} .
$$

The variables in these equations are expressed on a dry, ash-free $\left({ }_{\text {daf }}\right)$ basis, where $\mathrm{C}$ is weight percent carbon, $\mathrm{H}$ is weight percent hydrogen, $\mathrm{S}$ is weight percent total sulfur, and $\mathrm{O}$ is weight percent oxygen calculated as: $O_{d a f}=100-C_{d a f}-H_{d a f}-S_{d a f}$. Because hydrogen in the COALQUAL data includes the hydrogen in moisture, the contribution of moisture to the hydrogen value is stochiometrically calculated (moisture $\times 0.1119)$ and subtracted from the reported hydrogen value, before calculation to a dry, ash-free basis. 
Mott Spooner values are calculated for $98 \%$ of the 5059 selected COALQUAL data records; values cannot be calculated for $2 \%$ of the records because they lack elemental data. Mott-Spooner values for fifteen data records exceed $\pm 1000 \mathrm{Btu} / \mathrm{lb}$ and are ignored, as are four records with relatively high (positive) Mott-Spooner values reported by a single laboratory. The distribution of Mott-Spooner values for the remaining 4961 data records is shown in figure A1.

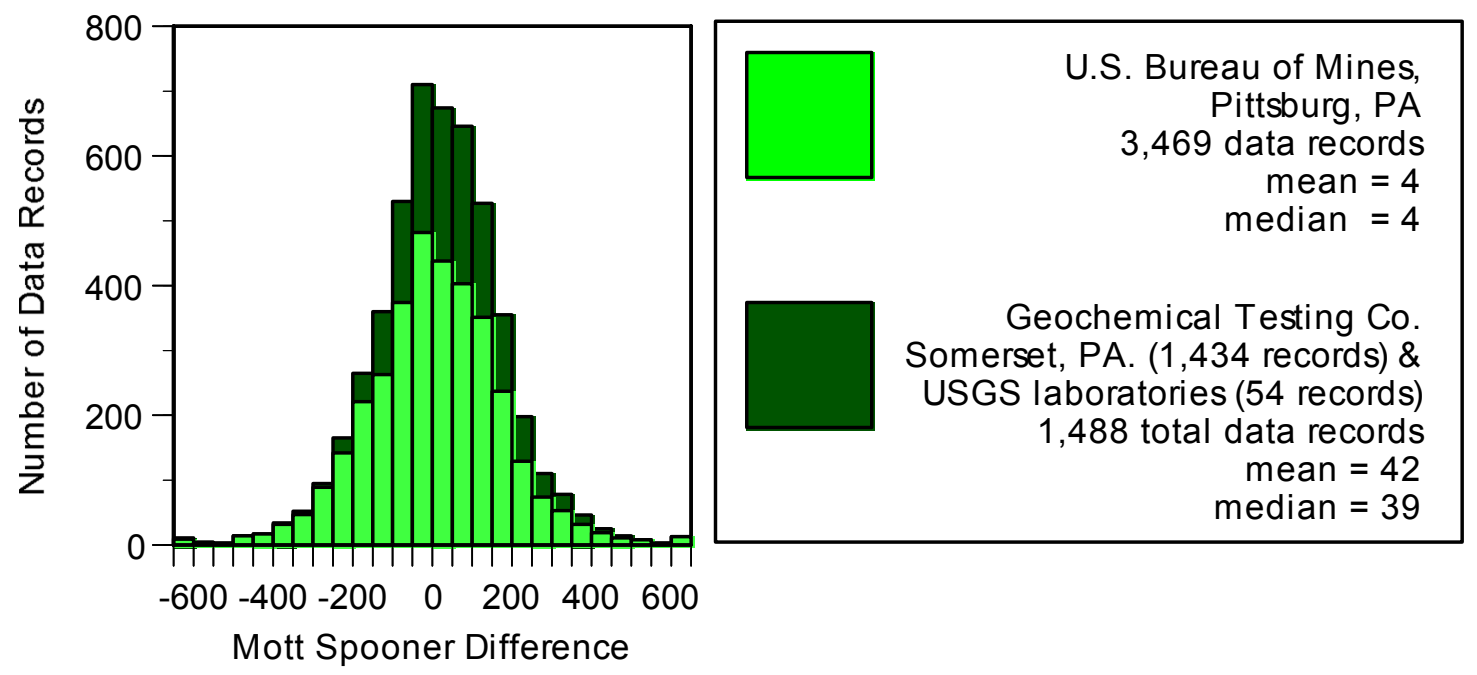

Figure A1. The distribution of Mott-Spooner difference values for 4957 selected COALQUAL data records is negligibly skewed about a mean near zero. A slight difference is observed between analytical laboratories.

The data in figure A1 are normally distributed about a median value of $+15 \mathrm{Btu} / \mathrm{lb}$. This trivial, positive value appears to be partly due to a difference between analytical laboratories illustrated in the figure. However, provincial variation of Mott-Spooner difference values shown in table A1 may also contribute to the slightly positive value. More remarkable, is that the mean Mott-Spooner difference for data from the U.S. Bureau of Mines laboratory is only $+4 \mathrm{Btu} / \mathrm{lb}$, which is essentially zero. 
Table A1. Provincial variation of Mott-Spooner difference values in the COALQUAL data.

\begin{tabular}{lccccc}
\hline Province & Eastern & Interior & Gulf & $\begin{array}{c}\text { Rocky } \\
\text { Mountain }\end{array}$ & $\begin{array}{c}\text { Northern } \\
\text { Great Plains }\end{array}$ \\
$\begin{array}{l}\text { Number of Records } \\
\begin{array}{l}\text { Average } \\
\text { Mott-Spooner Difference }\end{array}\end{array}$ & 3071 & 471 & 91 & 755 & 573 \\
$\begin{array}{l}\text { Median } \\
\text { Mott-Spooner Difference }\end{array}$ & 1 & 22 & 1 & 40 & 49 \\
\hline
\end{tabular}

${ }^{1}$ includes four records from the Pacific province.

Mott and Spooner (1940) stated that the difference between the calculated and the measured heating value should be within $\pm 100 \mathrm{Btu} / \mathrm{lb}$; if not, they suggested that the results of the elemental analysis should be suspected and repeated. Given and others (1986) argued that no precise limits of acceptability can be stated, but that the data are probably wrong if the difference exceeds $\pm 250 \mathrm{Btu} / \mathrm{lb}$. About $11 \%$ of the records shown in figure A1 exceed this threshold; 230 records have Mott-Spooner values $<250 \mathrm{Btu} / \mathrm{lb}$, and 296 records have Mott-Spooner values $>250 \mathrm{Btu} / \mathrm{lb}$. 


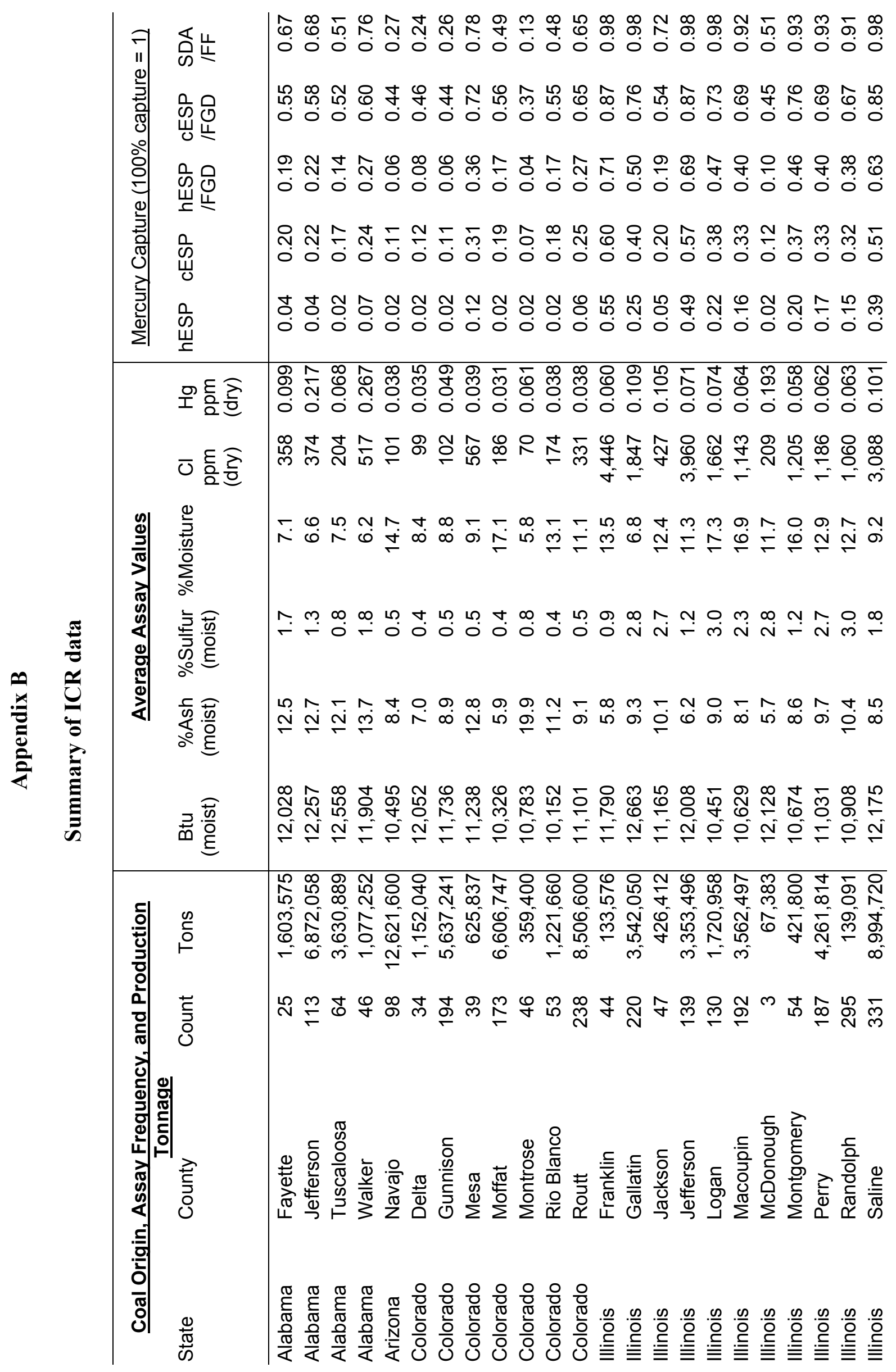




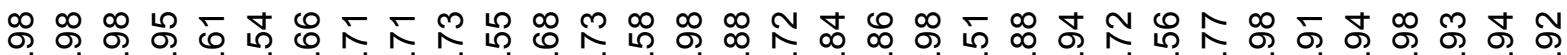

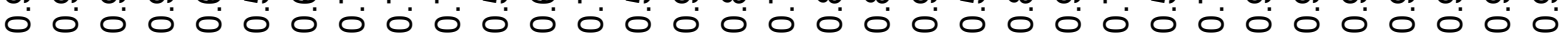

花 O

ธำ

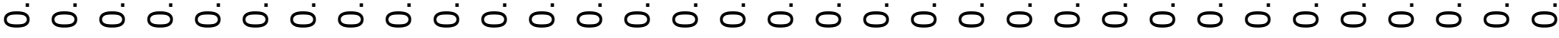

จ ๆ

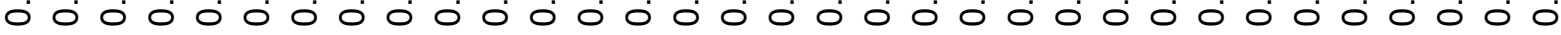

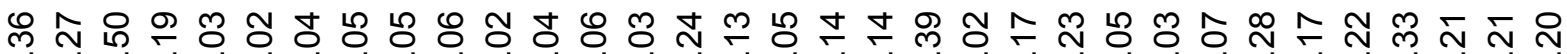

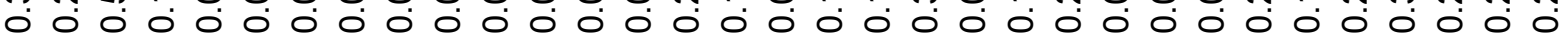

苞 O бo $-\nabla 000$ l

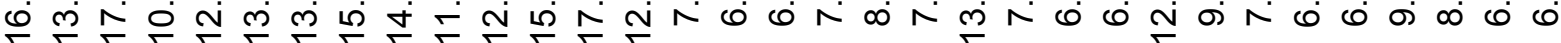

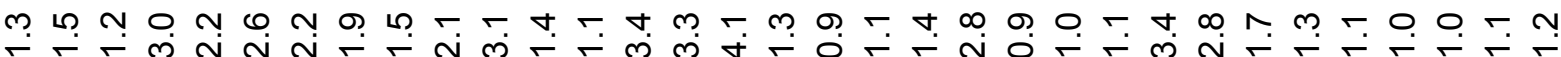

$\infty$ 舟 $\infty$ 유 후

앙

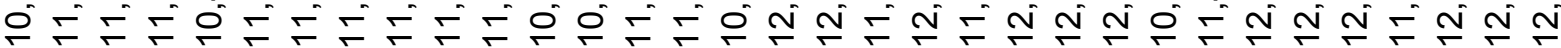

సั่

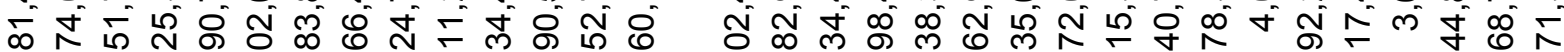
虽 m N

ホัர

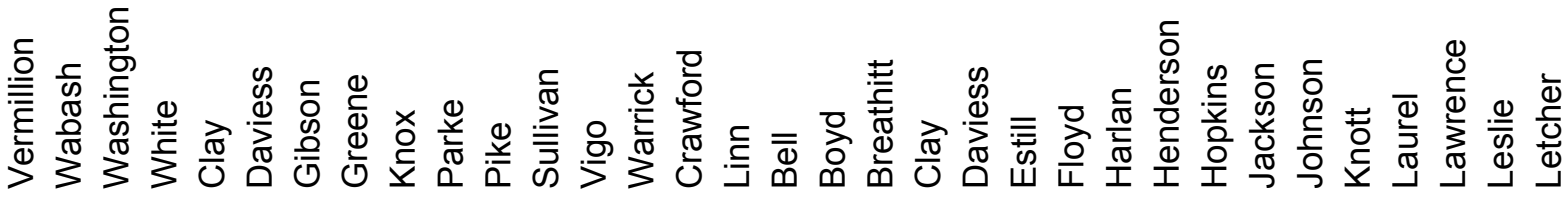

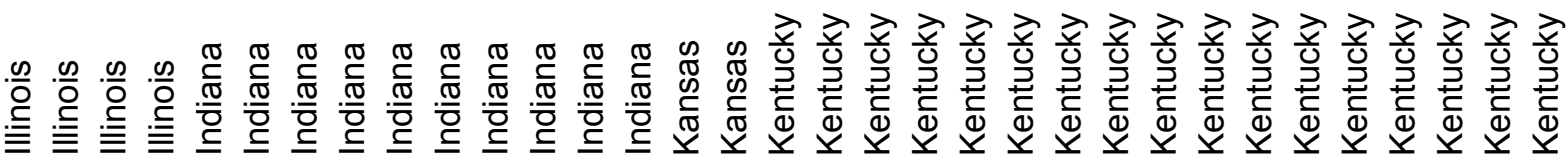




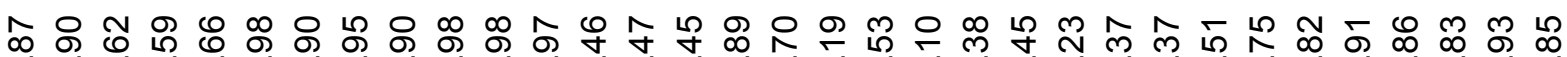

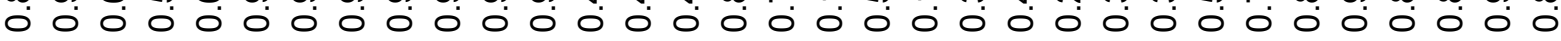

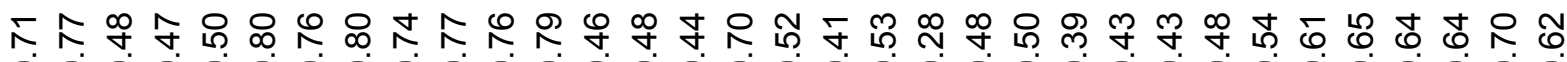

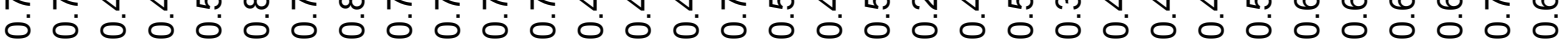

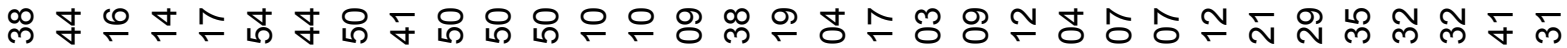
00000000000000000000000000000000000

స్

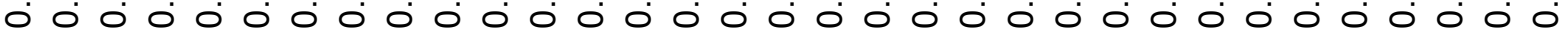

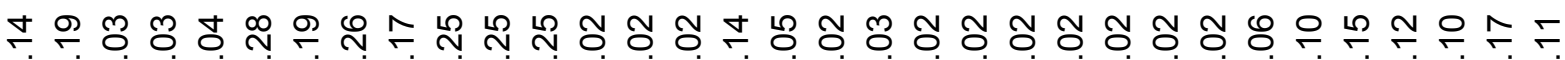

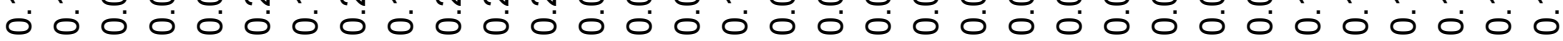

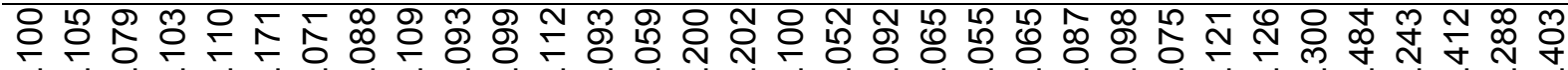
范 施

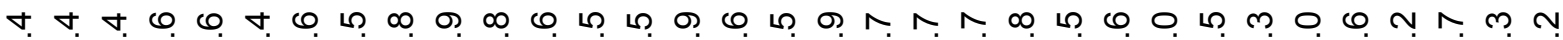

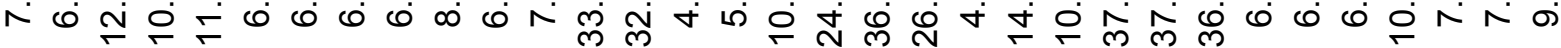

m $\because 0$ m

† 음

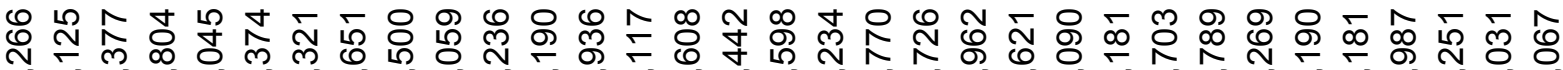

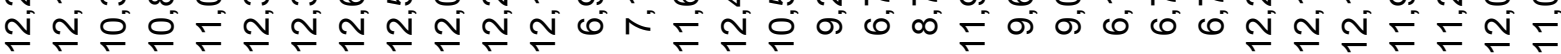

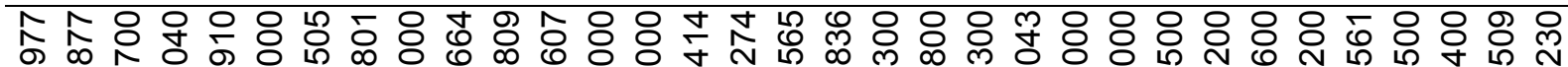

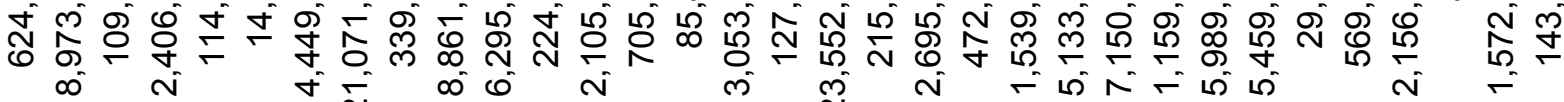

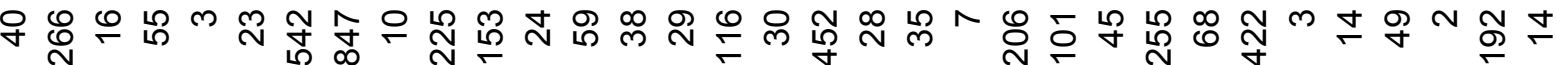

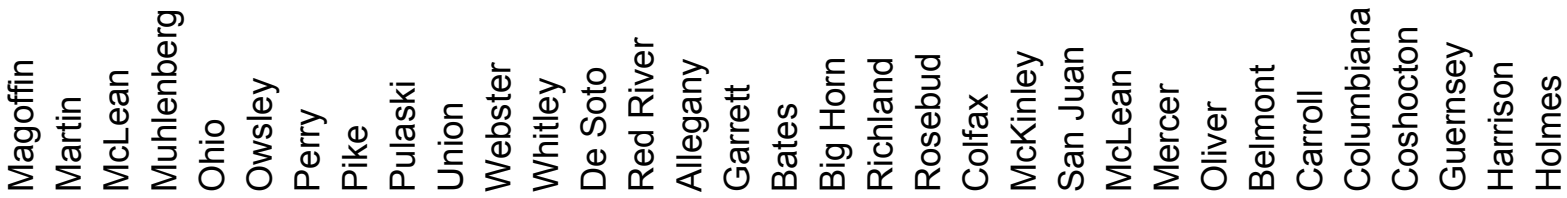

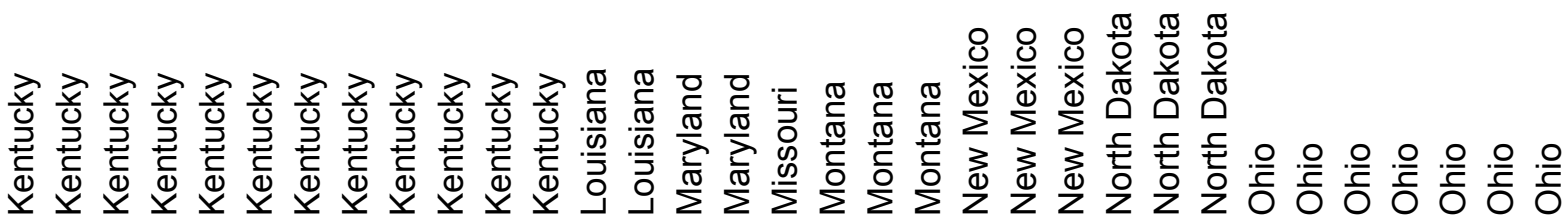


ம

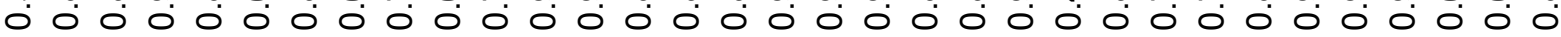

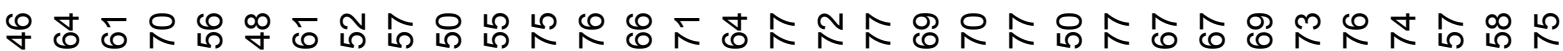

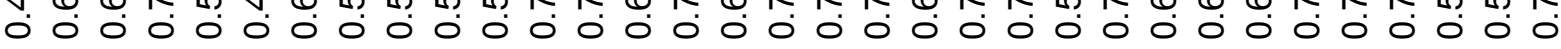

m

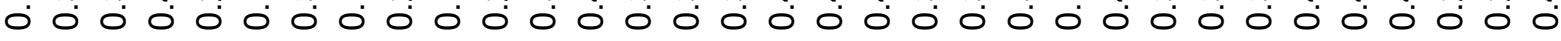

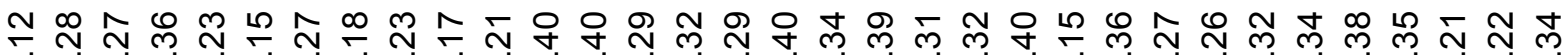

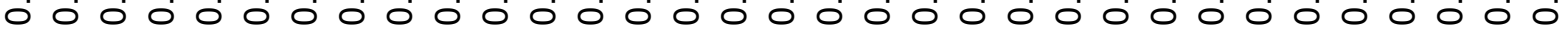

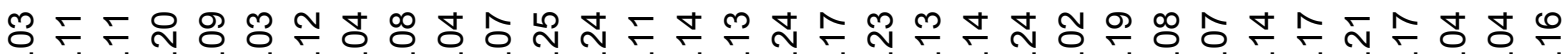
O

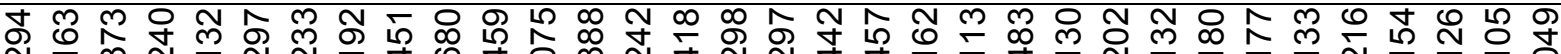
ஸָ

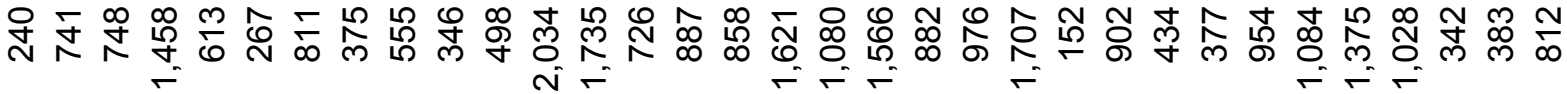
บ 수

r

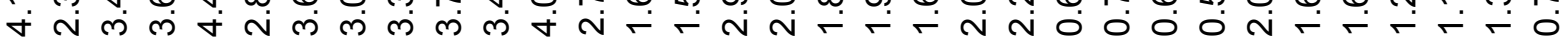

0 .

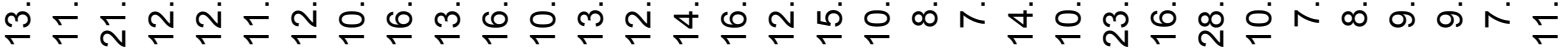

D

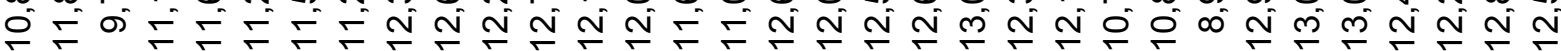

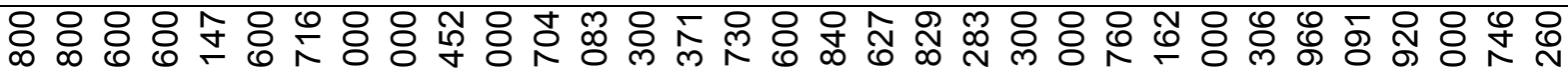

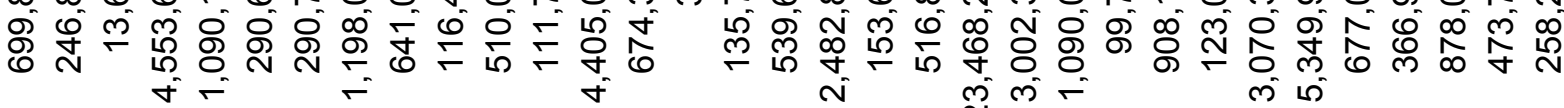
"ॄ

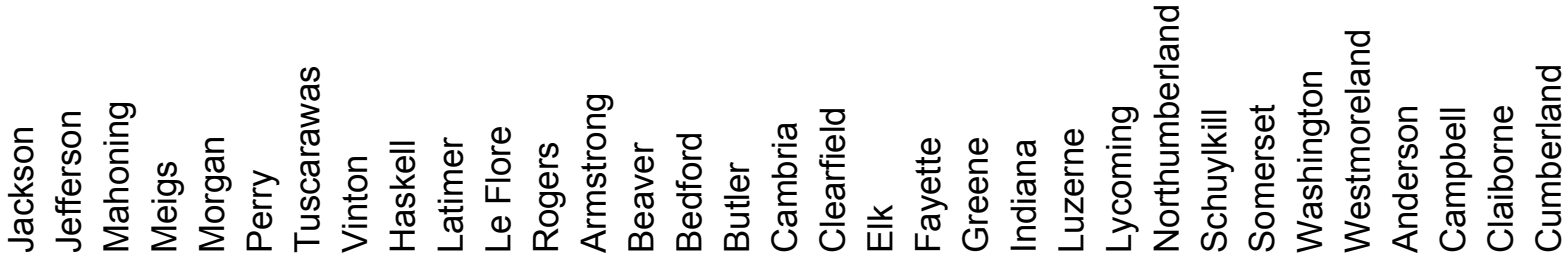

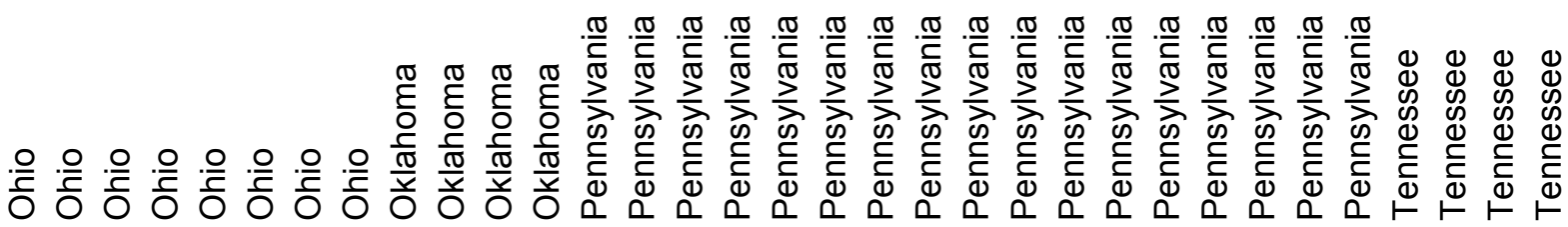


ษั

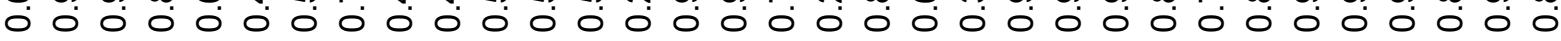

以ำ

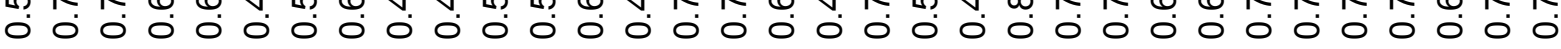

단 壬

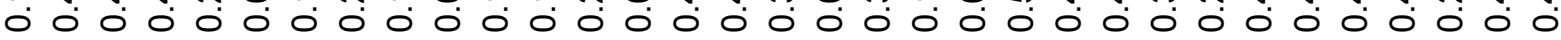

임

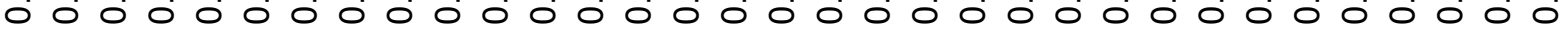

กำกㄴำㅇำ

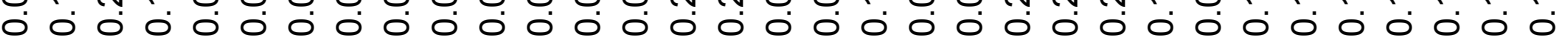

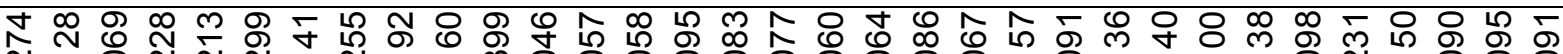
స్

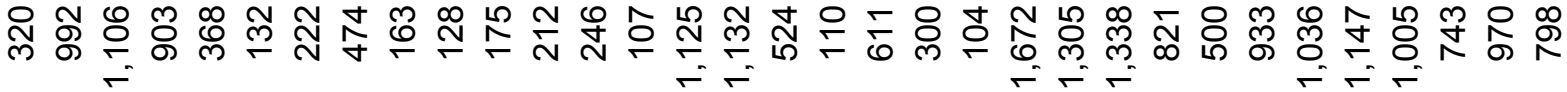

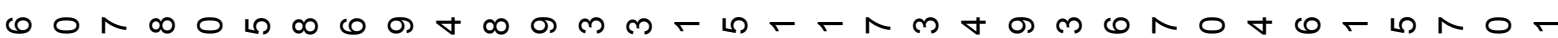

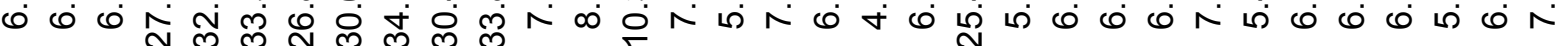

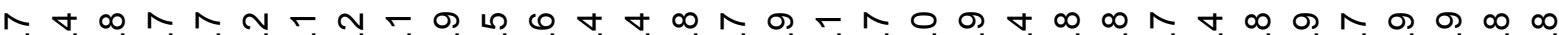

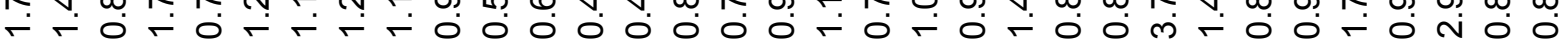

$\infty$ の 음ำ

羿 N $\cong$ แ

윳워 $\checkmark$ กิ N

- 마

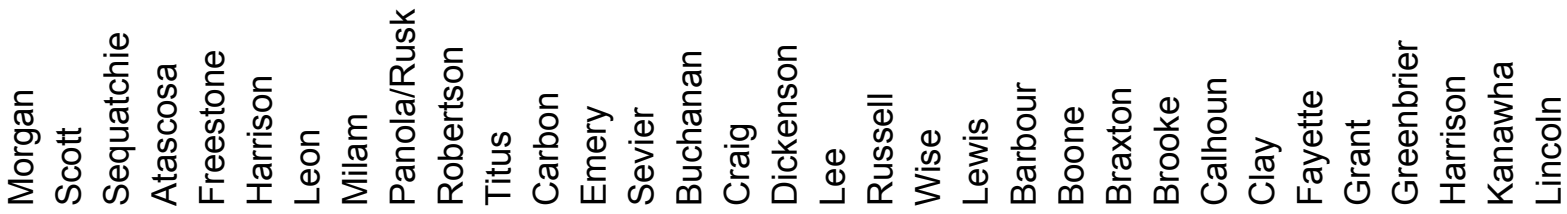

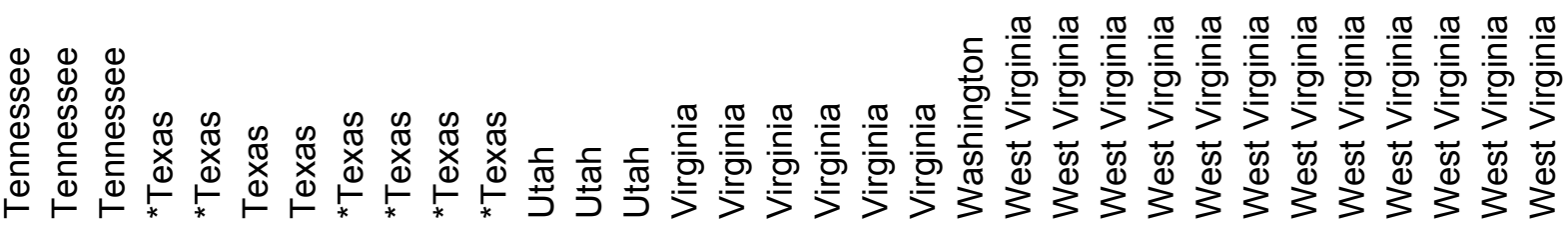




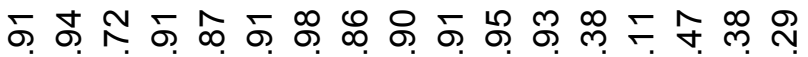
०००000000000000000

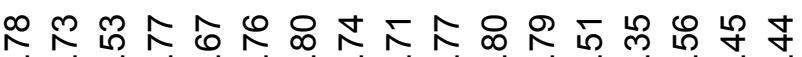

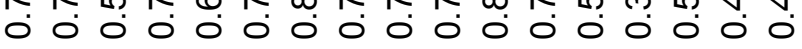

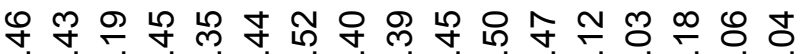

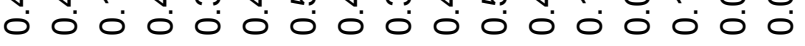

స్

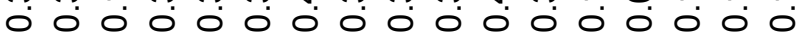

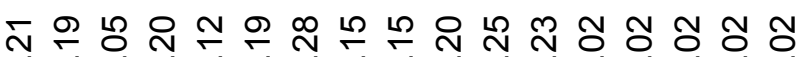

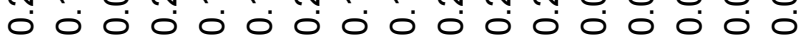

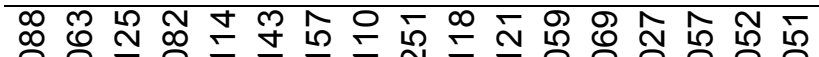
O O०

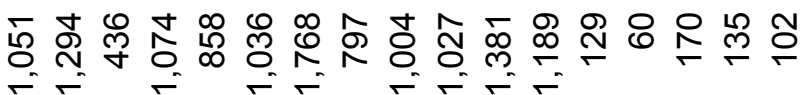
$04 \pi$. ம

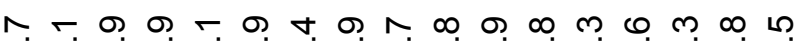
ல ก

オ

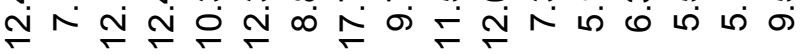

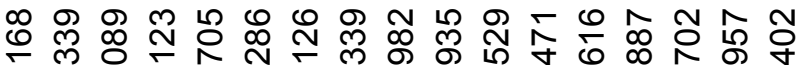

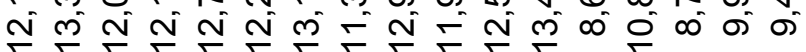

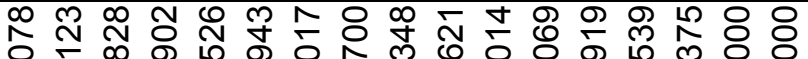

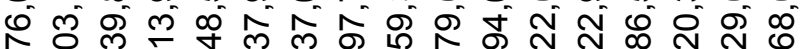
N

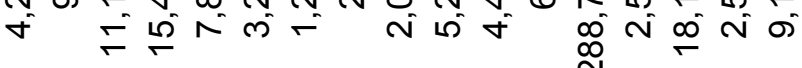

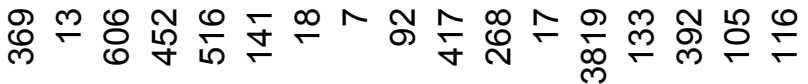
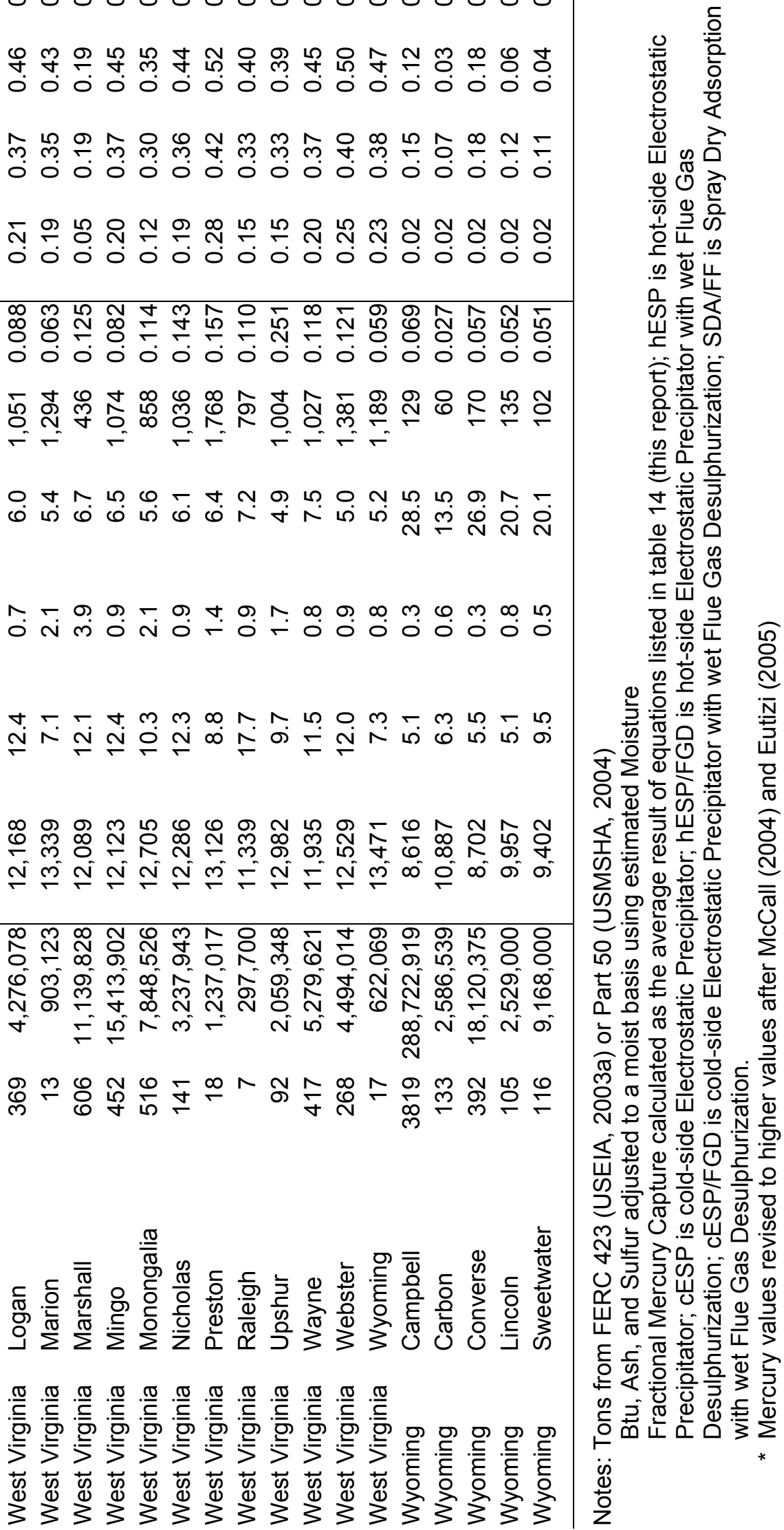


\section{GLOSSARY}

ASTM

Btu/lb

$\mathrm{Btu} / \mathrm{lb}$ m,mf

$\mathrm{Btu}_{\text {net }}$

COALQUAL

CTRDB

cESP

daf

DOE

ESP

FGD

FF
American Society for Testing and Materials.

gross British thermal units per pound coal on a moist, whole-coal basis as reported from the laboratory (multiply by 0.002326 to convert to $\mathrm{MJ} / \mathrm{kg}$ ).

British thermal units per pound coal, on a moist, mineral-matter-free basis calculated as, Btu / I $b_{m, m m f}=\frac{100(B t u / l b-50 \text { Sulfur })}{(100-[1.08 \text { Ash }-0.55 S])}$, where the sulfur, ash and $\mathrm{Btu} / \mathrm{lb}$ values are on a moist, whole-coal basis.

Net British thermal units per pound coal, reported on a whole-coal, moist basis. Also called the lower heating value, this calculated value is less than the Btu value reported from the laboratory in proportion to the amount of water vapor in gaseous combustion products. It can be calculated as $=$ Btu $-92.7(0.1119$ Moisture + Hydrogen $)$ where both Btu and hydrogen are reported on a moist basis, but hydrogen excludes hydrogen in coal moisture.

Coal quality database from the U.S. Geological Survey.

Coal Transportation Rate Data Base from the U.S. Energy Information Administration.

cold-side Electrostatic Precipitator. (see ESP)

A dry, ash-free reporting basis, usually noted as a subscript associated with a coal assay value. Dry, ash-free basis values are obtained by multipling, moist, whole-coal assay values by the factor:

$\frac{100}{(100-\text { Ash - Moisture })}$, where ash and moisture values are on a moist, whole-coal basis.

U.S. Department of Energy.

Electrostatic Precipitator. Called a cold-side ESP (cESP) when installed downstream of the air pre-heater (where temperatures typically range from 140 to $160^{\circ} \mathrm{C}$ ) and called a hot-side ESP (hESP) when installed before the air pre-heater (where temperatures typically range from 350 to $450{ }^{\circ} \mathrm{C}$ ).

wet Flue Gas Desulfurization. An emission control technology designed to remove SO2 from flue gas, usually installed after a particulate collection device; sulfur is removed as flue gas passes through an aqueous, alkaline solution (typically made with lime or limestone).

Fabric Filter. An emission control device, also called a baghouse, that removes solid particles from combustion flue gas. 
hESP

EIA

EPA

FERC

FERC 423

ICR

$\operatorname{lbs} \mathrm{Cl} / 10^{9} \mathrm{Btu}$

lbs $\mathrm{Hg} / 10^{12}$ Btu

lbs Hg/TW-h

lbs $\mathrm{S} / 10^{6} \mathrm{Btu}$

MW

ppm

PRB

PSU

SDA hot-side Electrostatic Precipitator. (see ESP)

\section{U.S. Energy Information Administration.}

\section{U.S. Environmental Protection Agency.}

Federal Energy Regulatory Commission.

A monthly data set listing the cost and quality of coal delivered to U.S. power plants.

Information Collection Request. Data collected during 1999 by the EPA to assist the development of any rules to limit mercury emissions from coal-fired utilities. The part 2 data list coal assay data for coal shipments, the part 3 data list measurements of mercury in stack gas

Pounds of chlorine per billion Btu $=\frac{10^{9}}{B t u} \times \frac{p p m C h l o r i n e}{10^{6}}$, where Btu and chlorine values are on the same reporting basis (for example, both dry basis or both moist basis. Multiply by 0.430 to convert to $\mathrm{kg} \mathrm{Cl} / \mathrm{TJ}$.

Pounds of mercury per trillion Btu $=\frac{10^{12}}{B t u} \times \frac{p p m \text { Mercury }}{10^{6}}$, where Btu and mercury values are on the same reporting basis (for example, both dry basis or both moist basis). Multiply by 0.430 to convert to $\mathrm{kg} \mathrm{Hg} / \mathrm{PJ}$.

Pounds mercury per terawatt hour, which is calculated in this report as: $=\frac{10^{12}}{B t u_{\text {net }}} \times \frac{p p m \text { Mercury }}{10^{6}} \times 10.26$ where both $B u_{\text {net }}$ and mercury are reported on a moist basis, and the coefficient, 10.26, corresponds to a nominal heat rate of 35\% (exactly 9,750 gross Btu/kilowatt-hour, which is approximately 10,260 net Btu/kilowatt-hour).

Pounds of sulfur per million Btu $=\frac{10^{6}}{B t u} \times \frac{\% \text { Sulfur }}{100}$, where Btu and sulfur values are on the same reporting basis (for example, both dry basis or both moist basis). Multiply by 0.430 to convert to $\mathrm{kg} \mathrm{S} / \mathrm{GJ}$.

Mega Watt, used to describe the power output from an electric generator. parts per million. Equals $\mu \mathrm{g} / \mathrm{g}$ or $\mathrm{mg} / \mathrm{kg}$.

Powder River Basin. Refers to coal produced from Campbell, Converse, and Sheridan Counties, Wyoming as well as Big Horn and Rosebud Counties, Montana.

Pennsylvania State University.

Spray Dry Adsorption. An emission control technology designed to remove SO2 from flue gas where gaseous sulfur is converted to a solid sulfate when an alkaline mist is injected into the flue gas; the solids are 
subsequently collected in a particulate filter. Usually used for low-sulfur western coal.

UGS

Utah Geological Survey.

USGS

United States Geological Survey. 
Plate 2. Sulfur in Commercial U.S. Coal by U.S. county of origin 1999 FERC 423 data




Plate 3. Chlorine in Commercial U.S. Coal by U.S. county of origin 1999 ICR data

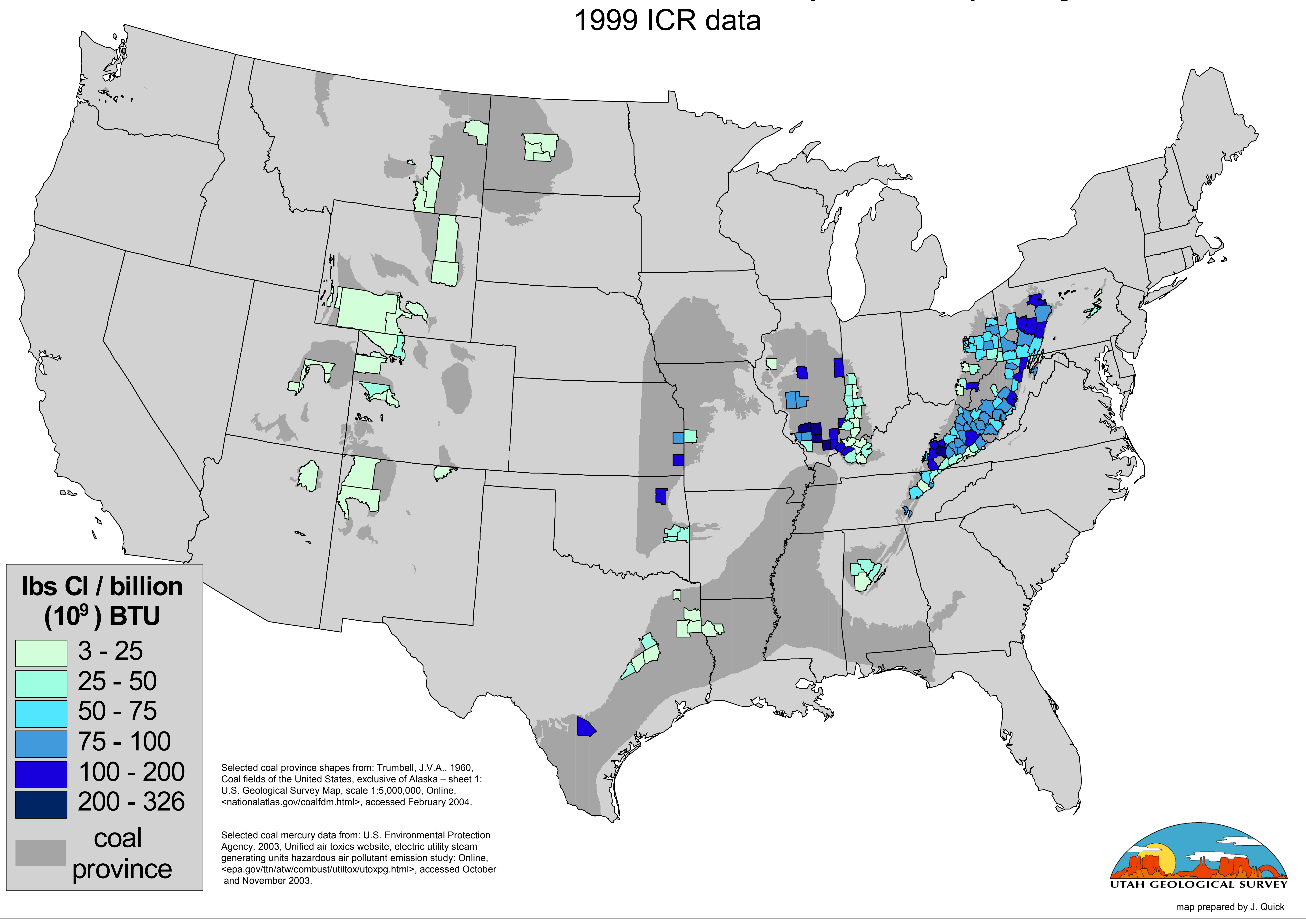


Plate 4. Moisture in Commercial U.S. Coal by U.S. county of origin Estimated for 1999 ICR data

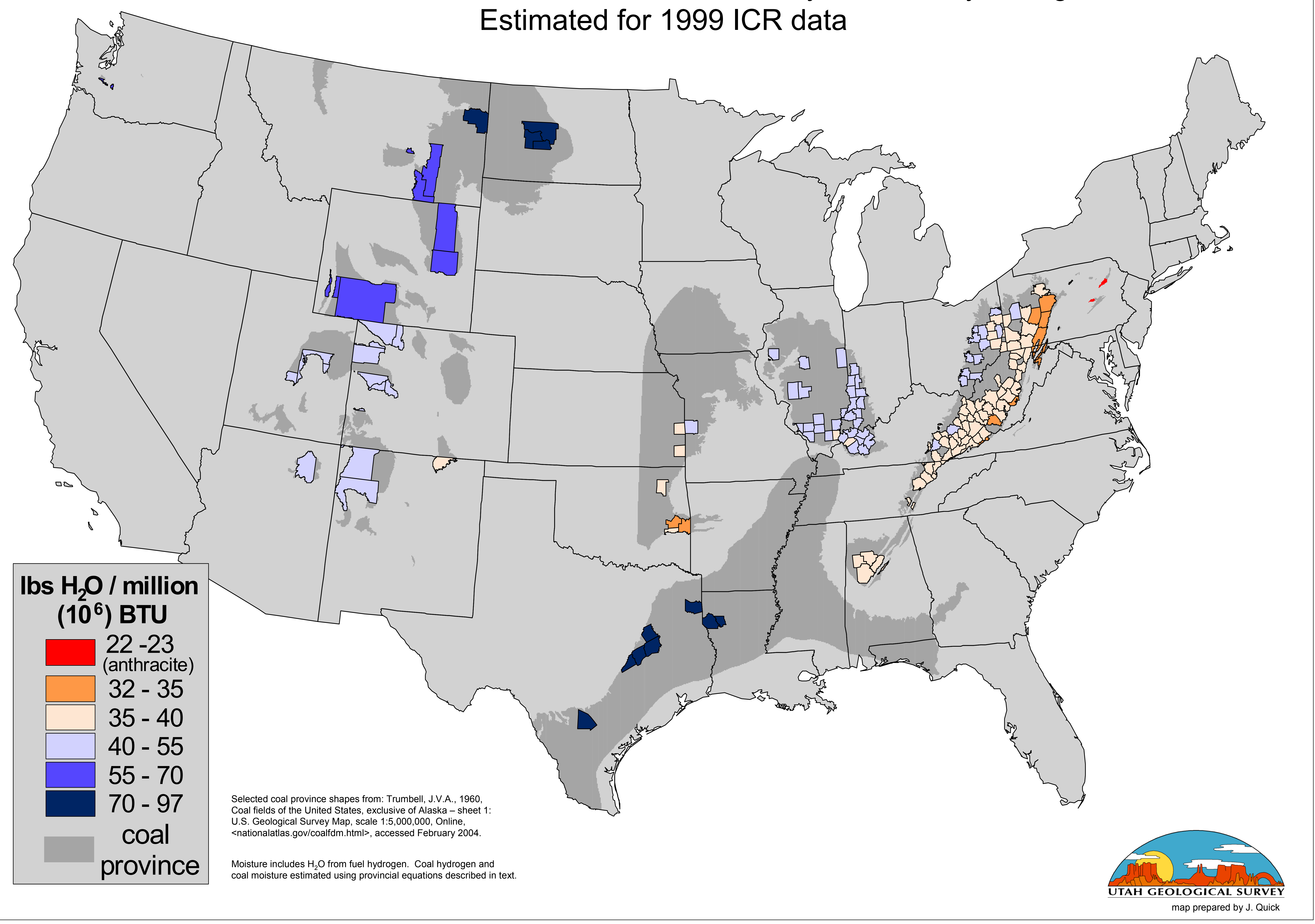




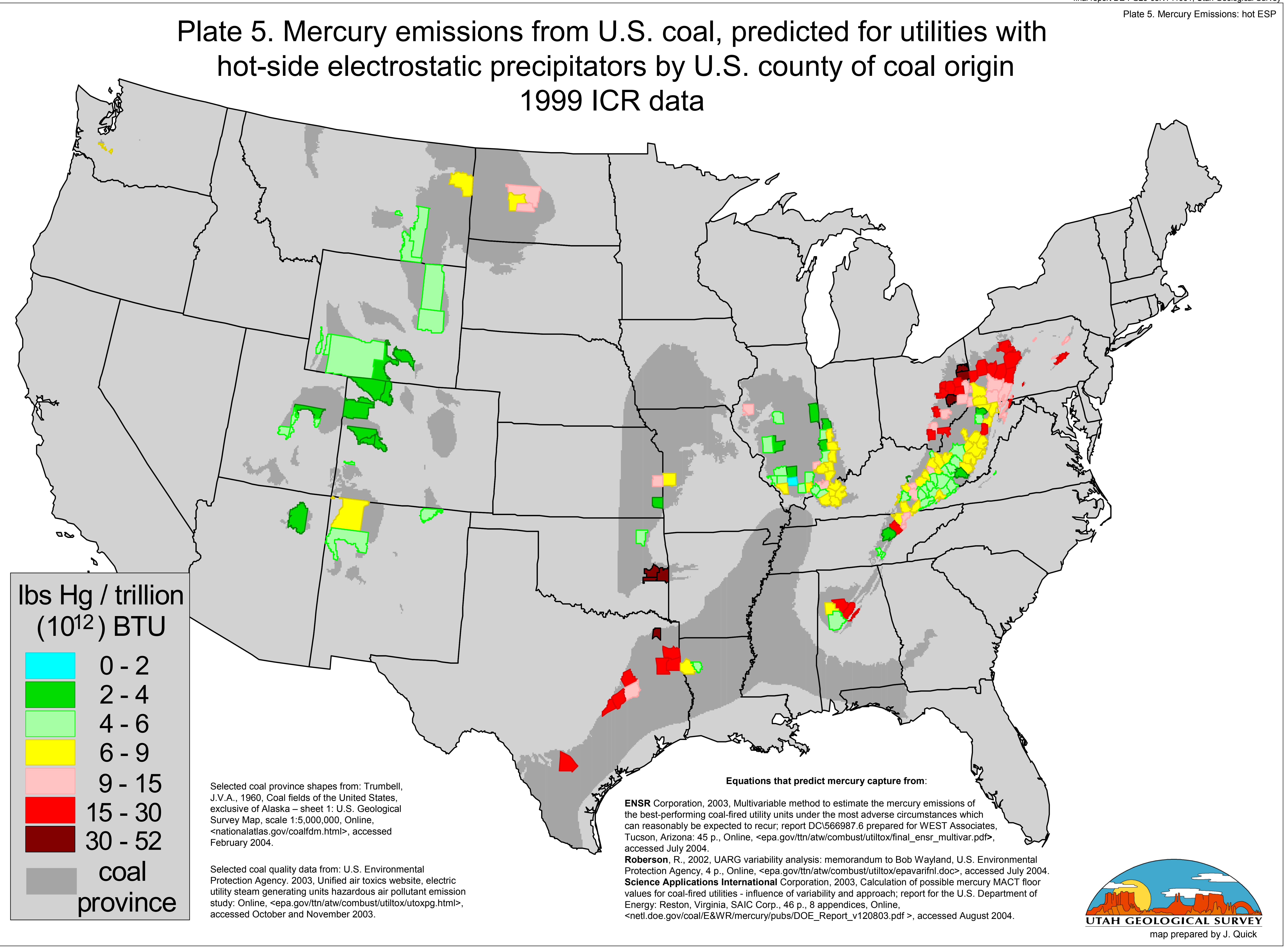


Plate 6. Mercury emissions from U.S. coal, predicted for utilities with

Plate 6. Mercury Emissions: cold ESP

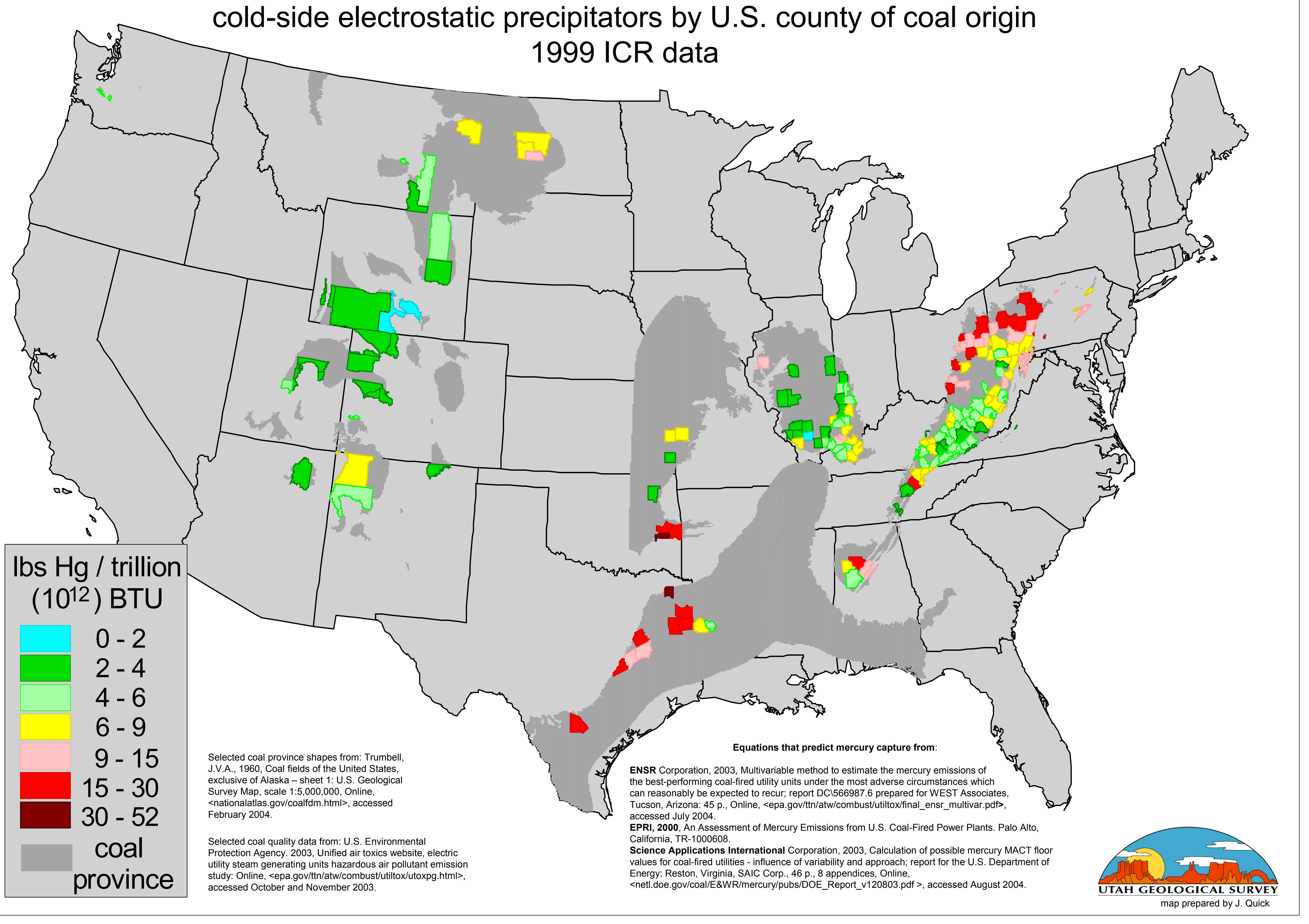


Plate 7. Mercury emissions from U.S. coal, predicted for utilities with hot-side electrostatic precipitators and wet flue gas desulphurization, by U.S. county of coal origin

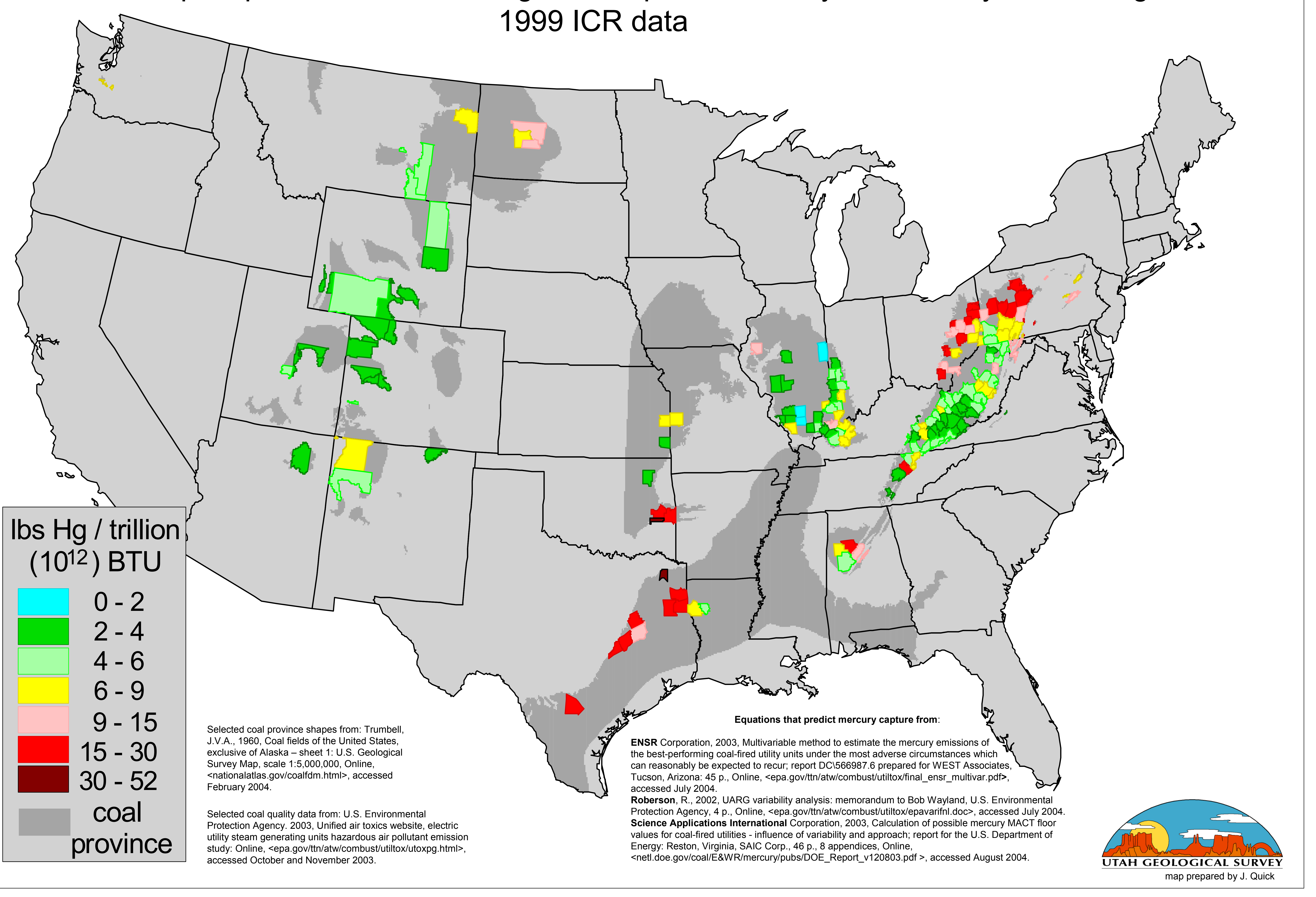


Plate 8. Mercury emissions from U.S. coal, predicted for utilities with cold-side electrostatic precipitators and wet flue gas desulphurization, by U.S. county of coal origin

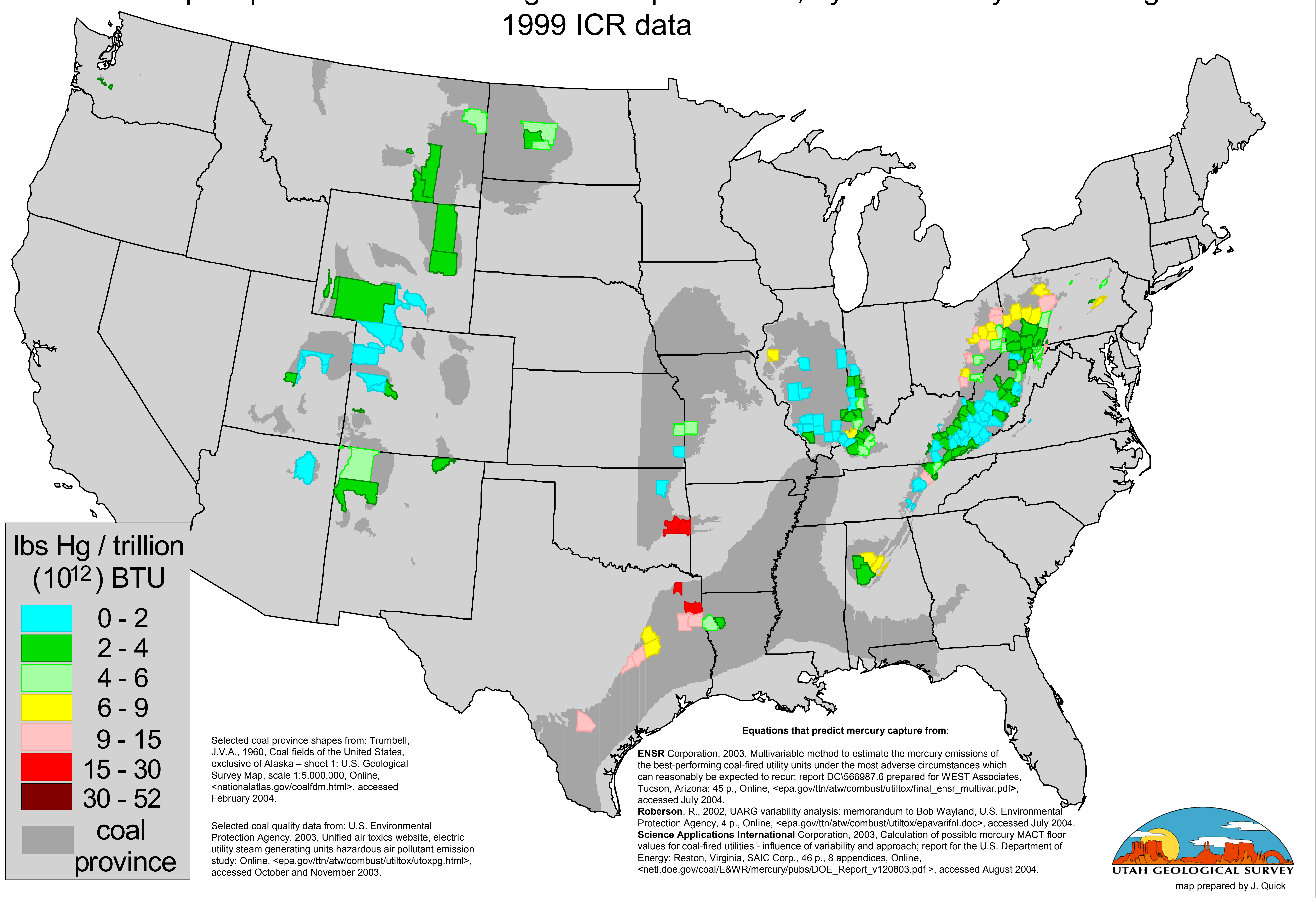


Plate 9. Mercury emissions from U.S. coal, predicted for utilities with spray-dry adsorption and fabric filters by U.S. county of coal origin

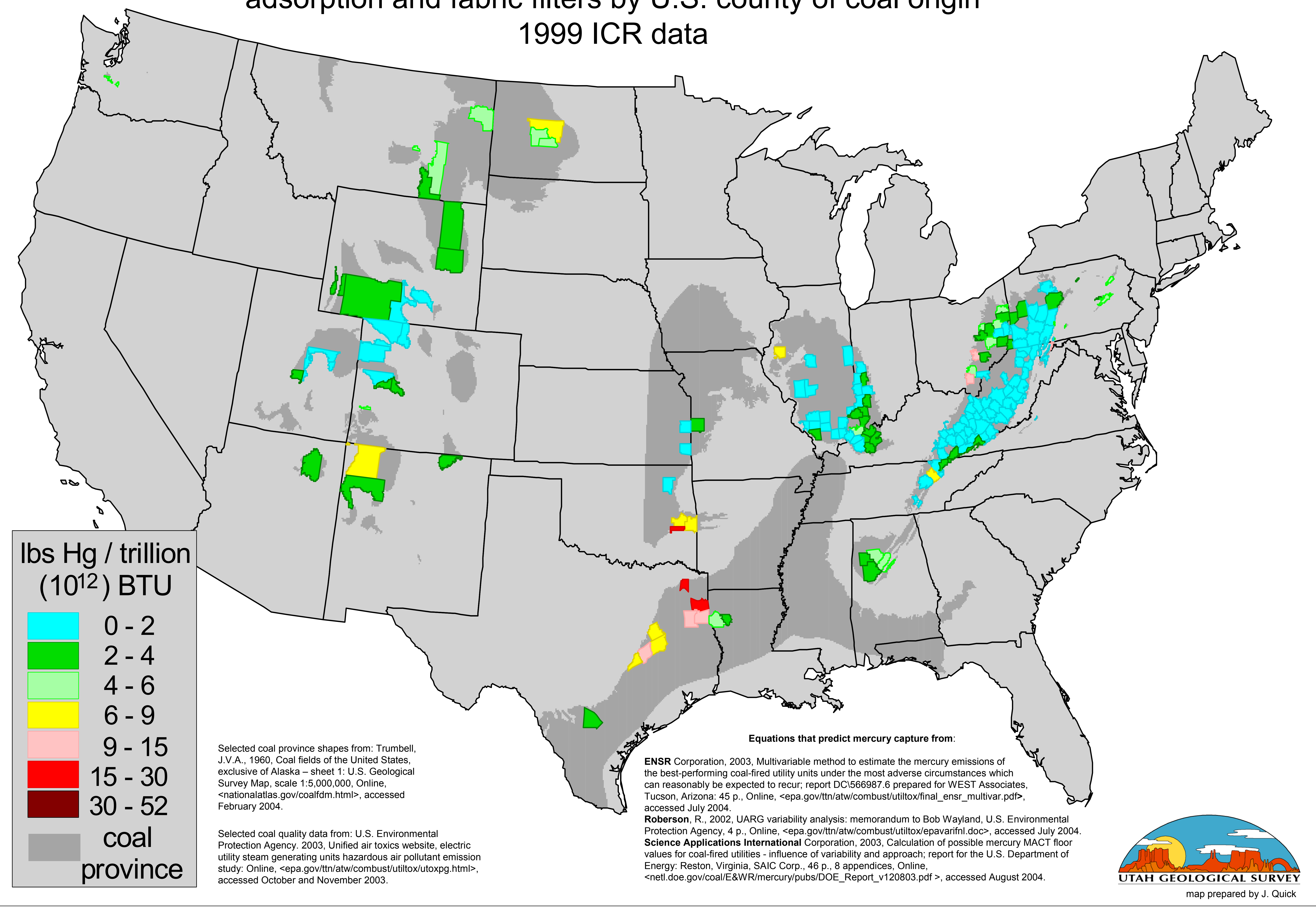


Plate 10. Potential mercury emission rate of commercial U.S. coal

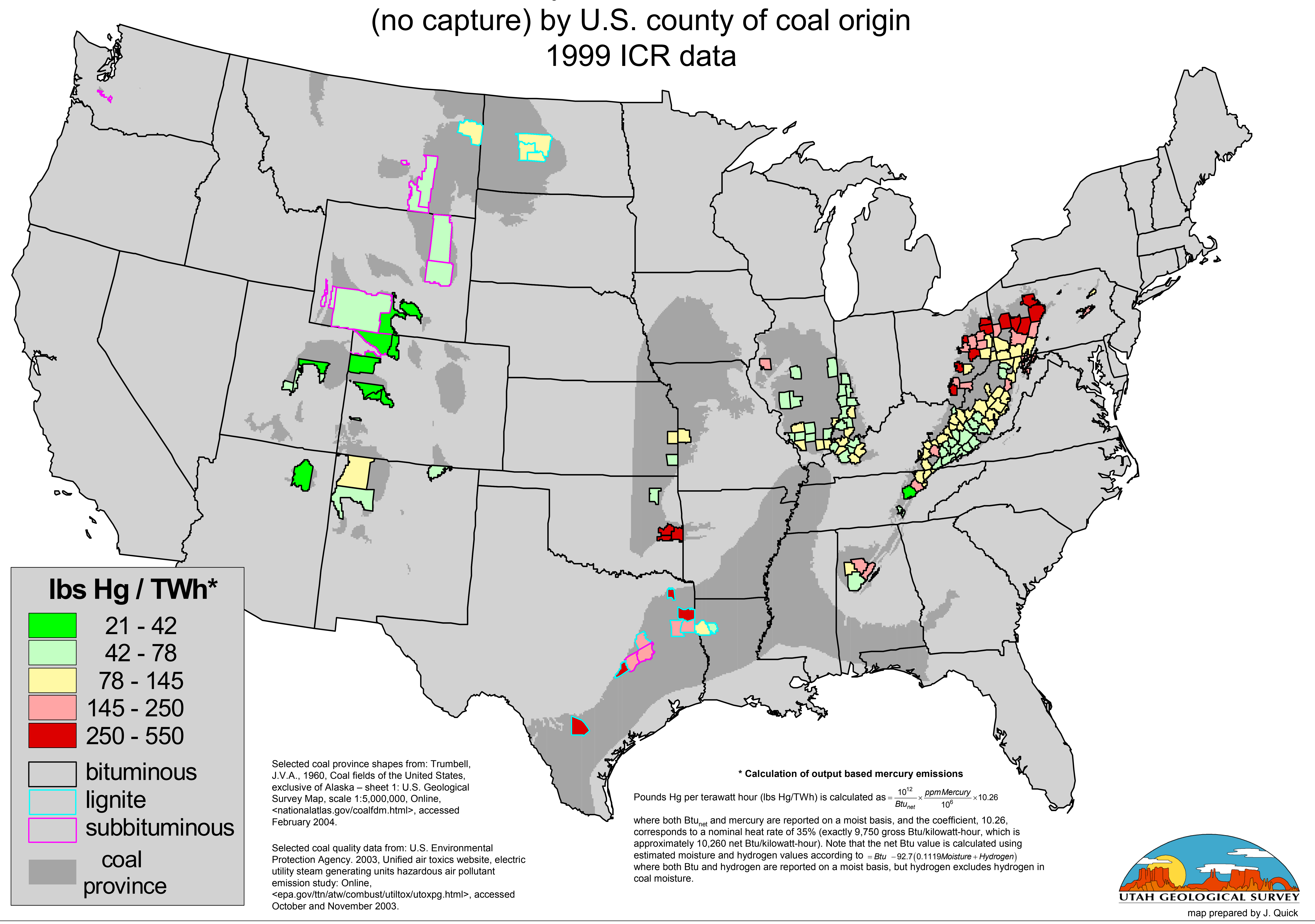

